\title{
Najważniejsze doniesienia z XII Ogólnopolskiej Konferencji po ASH (American Society of Hematology)
}

\author{
The highlights of the $12^{\text {th }}$ Polish Conference post-ASH \\ (American Society of Hematology)
}

\author{
Krzysztof Warzocha \\ Klinika Hematologii, Instytut Hematologii i Transfuzjologii, Warszawa
}

\section{Wprowadzenie}

2 i 3 marca 2018 roku w Krakowie odbyła się XII Ogólnopolska Konferencja po ASH stanowiąca przegląd najważniejszych wydarzeń naukowych opublikowanych w trakcie 59. Konferencji Amerykańskiego Towarzystwa Hematologów (ASH, American Society of Hematology) w grudniu 2017 roku w Atlancie. W ramach tegorocznej edycji odbyło się kilka sesji edukacyjnych i satelitarnych obejmujących swoim zakresem nowotwory układów chłonnego i krwiotwórczego, leczenie przeciwnowotworowe u osób $\mathrm{w}$ podeszłym wie$\mathrm{ku}$, transplantologię, immunologię i zaburzenia hemostazy oraz wykład, na którym przedstawiono najważniejsze doniesienia opublikowane w trakcie 59. Konferencji ASH.

\section{Szpiczak plazmocytowy}

prof. dr hab. n. med. Krzysztof Jamroziak

W czasie 59. Konferencji ASH zaprezentowano 981 doniesień ustnych i plakatowych dotyczących biologii, diagnostyki i terapii nowotworów plazmocytowych. Podobnie jak poprzednie również ta ostatnia konferencji dostarczyła wielu nowych informacji, które wkrótce przyczynią się do zmian $\mathrm{w}$ obowiązującej strategii diagnostyki i leczenia chorych na szpiczaka plazmocytowego (PCM, plasma cell myeloma). Do wyróżniających się nowych koncepcji należy zaliczyć przede wszystkim tendencję do wczesnego rozpoczynania leczenia $\mathrm{u}$ niektórych chorych $\mathrm{z}$ rozpoznaniem tlącego się PCM (SMM, smouldering multiple myeloma). $\mathrm{Na}$ Konferencji ASH w 2017 roku przedstawiono wstępne wyniki dwóch względnie dużych badań klinicznych CESAR (Carfilzomib, Lenalidomide and Dexamethasone [KRd] As Induction Followed By HDT-ASCT, Consolidation with Krd and Maintenance with $R d$ ) (streszczenie 402) i CENTAURUS (Daratumumab Monotherapy for Patients with Intermediate or High-Risk Smoldering Multiple Myeloma $[S M M]$ ) (streszczenie 510), których wyniki przemawiają za celowością wczesnej interwencji w grupie pacjentów z SMM obarczonych czynnikami ryzyka szybkiej progresji do fazy objawowej. Ponadto rosnąca $z$ roku na rok liczba prezentacji klinicznych na ten temat wyraźnie wskazuje, $\dot{z}$ e zdecydowanie najbardziej rozwijanym kierunkiem leczenia jest obecnie immunoterapia, przy czym różne strategie immunoterapii i immunochemioterapii są badane na każdym etapie przebiegu PCM. Należy w tym przypadku wyróżnić zaawansowane próby kliniczne dołączenia przeciwciał monoklonalnych, szczególnie skierowanych przeciwko antygenowi CD38, do praktycznie wszystkich stosowanych obecnie schematów chemioterapii, zarówno w pierwszej linii leczenia, jak i u pacjentów $z$ chorobą oporną lub/i nawrotową. Mniej zaawansowane pod względem rozwoju klinicznego, ale nawet bardziej obiecujące są terapie komórkowe, szczególnie leczenie za pomocą modyfikowanych limfocytów $\mathrm{T} z$ chimerycznym receptorem (CAR-T, chimeric antigen receptor $T$ ), testowane obecnie u pacjentów opornych na większość standardowych metod leczenia. Szczególnie godne uwagi wydają się wczesne wyniki badań służących ocenie CAR-T skierowane przeciwko antygenowi BCMA (B-cell maturation antigen).

Adres do korespondencji: Krzysztof Warzocha, Klinika Hematologii, Instytut Hematologii i Transfuzjologii, ul. Indiry Gandhi 14, 02-776 Warszawa, e-mail: warzocha@ihit.waw.pl 
Przed bliższym omówieniem istotnych doniesień na temat SMM wysokiego ryzyka warto przypomnieć, że obowiązującym obecnie standardem postępowania w przypadku tej choroby jest obserwacja. Nie dotyczy to jednak chorych obciążonych bardzo wysokim ryzykiem progresji, czyli $z$ obecnością co najmniej jednego $z$ następujących parametrów: więcej niż jedna zmiana ogniskowa stwierdzona metodą rezonansu magnetycznego, $60 \%$ lub więcej klonalnych plazmocytów w badaniu szpiku kostnego lub stosunek wolnych łańcuchów lekkich w surowicy równy 100 lub wyższy, u których według ostatnich kryteriów IMWG (International Myeloma Working Group) z 2014 roku, należy rozpoznać PCM i niezwłocznie rozpocząć chemioterapię. Przedstawione na ostatniej konferencji ASH wyniki badań klinicznych sugerują jednak potrzebę wczesnego rozpoczęcia leczenia w znacznie szerszej grupie pacjentów. Do obejmującego jedną grupę badania II fazy - CESAR (streszczenie 402), prowadzonego przez badaczy z hiszpańskiej grupy GEM, zakwalifikowano 90 pacjentów $z$ rozpoznaniem PCM i obarczonych czynnikami wysokiego ryzyka progresji. Czynniki te obejmowały zarówno parametry ryzyka uznawane w kryteriach Mayo Clinic (stężenie białka monoklonalnego $\mathrm{w}$ surowicy $\geq 3 \mathrm{~g} / \mathrm{dl}$ i/lub naciek plazmocytowy w szpiku kostnym $\geq 10 \%$ komórek jądrowych), jak i kryteria grupy hiszpańskiej (> 95-proc. przewaga plazmocytów o aberrantnym fenotypie nad prawidłowymi plazmocytami w szpiku kostnym lub/i cechy immunoparezy). Celem badania CESAR była ocena długoterminowej skuteczności i toksyczności bardzo intensywnego protokołu obejmującego indukcję za pomocą 6 cykli według schematu KRd (karfilzomib, lenalidomid, deksametazon), następnie podanie dużych dawek melfalanu (Mel) z przeszczepieniem autologicznych krwiotwórczych komórek macierzystych (auto-HSCT, autologous stem cell transplantation), konsolidację za pomocą 2 cykli KRd i dodatkowo leczenie podtrzymujące lenalidomidem przez 2 lata. Według zaprezentowanych podczas konferencji wczesnych wyników badania CESAR (mediana czasu obserwacji 10 miesięcy) wszyscy chorzy, który zakończyli fazę konsolidacji, KRd ( $\mathrm{n}=35)$ uzyskali całkowitą remisję (CR) choroby, a $60 \%$ $z$ nich — również ujemny wynik badania w kierunku obecności minimalnej choroby resztkowej (MRD, minimal residual disease). Wykazano zatem wysoką częstość głębokich odpowiedzi, jednak dopiero długofalowa obserwacja pozwoli odpowiedzieć na pytanie, czy tak intensywna chemioterapia umożliwi wyleczenie części chorych na SMM.
Inne, znacznie mniej intensywne, podejście do terapii SMM wysokiego ryzyka oceniono w randomizowanym badaniu II fazy CENTAURUS (streszczenie 510). W ramach protokołu badania 123 pacjentów przydzielono losowo do 3 grup różniących się sposobem stosowania daratumumabu w monoterapii. W schemacie leczenia „długim i intensywnym” zakładano częste infuzje daratumumabu przez maksymalnie 3 lata, w schemacie pośrednim - dłuższe odstępy między infuzjami leku przez maksymalnie 3 lata, a w schemacie „krótkim” uwzględniano tylko jeden cykl składający się z 4 infuzji w odstępach tygodniowych. W badaniu wykazano bardzo dobrą tolerancję daratumumabu w SMM, przy czym schemat intensywny charakteryzował się zdecydowanie najlepszą skutecznością $z$ całkowitym odsetkiem odpowiedzi (ORR, overall response rate) wynoszącym $56 \%$ oraz $93 \%$ chorych pozostającymi bez progresji po roku obserwacji. Zadowalające wyniki badania CENTAURUS stały się podstawą do opracowania protokołu toczącego się badania III fazy, które prawdopodobnie doprowadzi do rejestracji daratumumabu we wskazaniu „SMM wysokiego ryzyka”.

W zakresie terapii pierwszej linii u pacjentów $z$ objawowym PCM najbardziej istotne wydają się doniesienia opisujące kombinacje przeciwciał monoklonalnych, szczególnie daratumumabu, ze standardowymi trójlekowymi schematami terapii indukującej remisję. Należy podkreślić, że wcześniejsze wysiłki na rzecz opracowania schematów czterolekowych kończyły się niepowodzeniem ze względu na nakładające się działania niepożądane poszczególnych chemioterapeutyków. Daratumumab natomiast jest w zasadzie pozbawiony kolidujących $z$ toksycznością chemioterapii działań niepożądanych, dlatego wydaje się bardzo dobrym kandydatem do takiej złożonej terapii. Najważniejsze $z$ tej grupy doniesień zaprezentowano w sesji Late breaking abstracts (LBA) i dotyczyło wyników dużego randomizowanego badania III fazy ALCYONE nad zastosowaniem schematu Dara-VMP (daratumumab, bortezomib, melfalan, prednizon) $\mathrm{w}$ pierwszej linii leczenia u chorych niekwalifikujących się do auto-HSCT (streszczenie LBA-4). W tym badaniu $z$ udziałem grupy ponad 700 chorych porównano standardowy schemat chemioterapii VMP (bortezomib, melfalan, prednizon), stosowany przez 9 cykli, $z$ tym samych schematem w skojarzeniu $z$ daratumumabem, który podawano co 3 tygodnie w czasie chemioterapii VMP, a następnie po jej zakończeniu — do progresji jako leczenie podtrzymujące raz $\mathrm{w}$ miesiącu. Zdecydowanie pozytywne wyniki badania ALCYONE ukazały 
zdecydowaną przewagę Dara-VMP nad VMP w odniesieniu do ORR (91\% w porównaniu $z$ 75\%), odsetka chorych $z$ ujemnym wynikiem badania MRD (22\% v. 6\%) i przeżyciem wolnym od progresji (PFS, progression-free survival) choroby (obnizenie ryzyka progresji o 50\%). Przewaga w zakresie czasu przeżycia (OS, overall survival) jest bardzo prawdopodobna, jednak wymaga dłuższego czasu obserwacji. Zasadniczo toksyczność schematu Dara-VMP jest akceptowalna, warto jednak zwrócić uwagę na zwiększone ryzyko ciężkich infekcji $(23,1 \% v .14,7 \%)$, które wiążą się prawdopodobnie $z$ immunosupresyjnym działaniem daratumumabu. Niewątpliwie, wyniki badania ALCYONE (Phase 3 Randomized Study of Daratumumab Plus Bortezomib, Melphalan, and Prednisone [D-VMP] Versus Bortezomib, Melphalan, and Prednisone [VMP] in Newly Diagnosed Multiple Myeloma [NDMM] Patients [Pts] Ineligible for Transplant) nad Dara-VMP są bardzo silnym argumentem na rzecz rutynowego stosowania immunochemioterapii w pierwszej linii leczenia chorych na PCM niekwalifikujących się do auto-HSCT.

Badania nad dołączeniem przeciwciał monoklonalnych do podstawowych schematów chemioterapii indukującej remisję są również prowadzone w grupie chorych młodszych, będących kandydatami auto-HSCT. Są one jednak mniej zaawansowane, co wynika również $z$ odmiennej koncepcji takiego leczenia, które jest krótkie i następuje po nim konsolidacja terapią wysokodawkowaną. Do najciekawszych doniesień $z$ tej kategorii należała prezentacja wstępnych wyników badania fazy Ib służącego analizie dołączenia daratumumabu do schematu KRd (streszczenie 3110). Wykazano, że wszyscy włączeni do badania chorzy $(\mathrm{n}=21)$ odpowiedzieli na immunochemioterapię Dara-KRd, przy czym większość pacjentów (57\%) uzyskało odpowiedź w postaci CR lub głębszą.

Strategie immunoterapii należą również do najbardziej badanych zagadnień w leczeniu pacjentów $z$ rozpoznaniem nawrotowego/opornego PCM. Na tym polu szczególnym zainteresowaniem w czasie kilku ostatnich lat cieszą się terapie z użyciem CAR-T. Najbardziej obiecującym celem dla komórek CAR-T w PCM wydaje się obecnie antygen BCMA - białko $z$ nadrodziny receptorów czynnika martwicy nowotworów (TNF, tumor necrosis factor), ulegające istotnej ekspresji tylko na zdrowych i patologicznych plazmocytach oraz części dojrzałych limfocytów. Na konferencji ASH w 2017 roku zaprezentowano kilka ważnych aktualizacji wstępnych badań z zastosowaniem CAR-T skierowanych przeciwko BCMA. Jedno $z$ bardziej interesujących doniesień dotyczyło amerykańskiego badania I fazy komórek CAR-T bb2121 (badanie CRB-401) u chorych na nawrotowy PCM, po co najmniej 3 liniach terapii lub z podwójną opornością na lek immunomodulujący i inhibitor proteasomu (streszczenie 740 ). W badaniu tym wykazano znaczą aktywność tej terapii, przy czym po medianie obserwacji wynoszącej 40 tygodni u 56\% pacjentów stwierdzono $\mathrm{CR}$, a 9 spośród 10 chorych, którym podano największą dawkę komórek CAR-T, uzyskało również eradykację MRD. Co istotne, uzyskane odpowiedzi wydają się trwałe - u części chorych utrzymują się już ponad 12 miesięcy. Również wstępne wyniki innych wczesnych badań opartych na tej samej koncepcji, ale różniących się metodami kondycjonowania przed infuzją CAR-T anty-BCMA lub dołączaniem do tej terapii innych leków, są obiecujące. Należy jednak zauważyć, że na obecnym etapie rozwoju ta metoda leczenia ma również istotne ograniczenia. Po pierwsze, jest to leczenie bardzo specjalistyczne i kosztowne, a także obarczone wysokim ryzykiem ciężkich powikłań, szczególnie zagrażającego życiu zespołu uwalniania cytokin. Po drugie, proces aferezy i przygotowania ex vivo komórek CAR-T jest czasochłonny, a więc do tego rodzaju terapii nie kwalifikują się pacjenci wymagający szybkiego rozpoczęcia leczenia. $Z$ tych względów inne, łatwiejsze do stosowania strategie immunoterapii przeciwko BCMA, również prezentowane na Konferencji ASH w 2017 roku, na przykład terapia bispecyficzna angażująca komórki T (BiTE, bispecific T-cell engager) lub przeciwciała monoklonalne anty-BCMA połączone $z$ auristatyną, mogą stanowić interesującą alternatywę dla CAR-T. Podsumowując zagadnienie leczenia nawrotowego i/lub opornego PCM, warto jednak zwrócić uwagę, że choć prezentacje dotyczyły często bardzo wyrafinowanych metod leczenia, to jednak informacje na temat zastosowania wszystkich tych leków raportowano już wcześniej. Zabrakło natomiast doniesień na temat całkowicie nowych, potencjalnie przełomowych terapii.

Mówiąc o terapii wspomagającej, należy wyróżnić niezwykle istotne klinicznie doniesienie prezentujące wyniki dużego brytyjskiego badania randomizowanego TEAMM (streszczenie 903), dotyczącego profilaktycznej antybiotykoterapii $\mathrm{u}$ chorych na PCM podczas pierwszych miesięcy chemioterapii. Jak wiadomo, śmiertelność $z$ powodu powikłań infekcyjnych jest $\mathrm{w}$ tym początkowym okresie leczenia największa. W ramach badania 977 pacjentów z 93 szpitali w Wielkiej Brytanii zostało w latach 2012-2016 losowo przydzielonych do profilaktycznego stosowania lewofloksacyny 
(w dawce $2 \times 250 \mathrm{mg} /$ d.) lub placebo przez pierwsze 12 tygodni chemioterapii. Wyniki badania wykazały jednoznaczną korzyść ze stosowania lewofloksacyny. Stwierdzono między innymi istotną redukcję liczby epizodów gorączkowych i zgonów (współczynnik ryzyka [HR, hazard ratio $]=0,66$; $\mathrm{p}=0,002$ ) oraz zmniejszenie liczby klinicznie i mikrobiologicznie udowodnionych infekcji, przy czym, co ważne, nie obserwowano wzrostu częstości objawowych zakażeń Clostridium difficile (C. difficile) ani wzrostu ryzyka nosicielstwa opornych bakterii, w tym $C$. difficile, Staphylococcus Aureus opornego na metycylinę (MRSA, anti-methicillin-resistant Staphylococcus Aureus) czy bakterii kałowych wytwarzającymi beta-laktamazy o rozszerzonym spektrum substratowym (ESBL, extended spectrum-beta-lactamase)(+) i Gram(-). Ponadto zaobserwowano niezależny efekt obniżenia ryzyka epizodów gorączkowych/zgonów u 315 pacjentów, u których stosowano, zgodnie z decyzją lekarza prowadzącego, sulfametoksazol-trimetoprim (HR $=0,52 ; \mathrm{p}=0,0009)$. Wyniki te silnie przemawiają za rutynowym stosowaniem opisanej profilaktyki antybiotykowej przynajmniej przez pierwsze 3 miesiące leczenia indukującego remisję u chorych na PCM.

$\mathrm{Na}$ ostatniej konferencji ASH więcej uwagi niż zazwyczaj poświęcono amyloidozie AL (AAL). Właśnie ta choroba była tematem prestiżowego wykładu Hama-Wassermana, który został wygłoszony przez bardzo zasłużonego w badaniach nad amyloidozą prof. Giampaolo Merliniego z Pavii. Wykład ten stanowił podsumowanie dotychczasowych osiągnięć w wyjaśnianiu patogenezy AAL oraz przegląd najnowszych metod diagnostycznych i terapii skierowanych przeciwko nowotworowym komórkom plazmatycznym oraz przeciwko złogom amyloidu. Wśród licznych interesujących doniesień zwracały uwagę przede wszystkim wyniki badań klinicznych nad zastosowaniem daratumumabu w AAL. W amerykańskim badaniu II fazy (streszczenie 507), do którego włączono dotychczas 8 chorych po medianie 3 wcześniejszych linii leczenia, wykazano znaczne zmniejszenie stężenia wolnych łańcuchów lekkich w surowicy po pierwszej infuzji przeciwciała, która następnie ulegała pogłębieniu w czasie kontynuacji leczenia trwającego do 6 miesięcy. Sześciu spośród 8 chorych osiągnęło bardzo dobrą odpowiedź częściową (VGPR, very good partial response), obserwowano również odpowiedzi narządowe. $\mathrm{W}$ drugiej prezentacji $z$ tej serii (streszczenie 508) podsumowano wstępne wyniki francuskiego wieloośrodkowego badania II fazy nad monoterapią daratumumabem. Wśród
24 ocenionych dotychczas chorych (mediana 69 lat, średnio po 2 . linii poprzedzającego leczenia) również obserwowano bardzo szybkie obniżenie stężenia monoklonalnych wolnych łańcuchów lekkich, średnio o ponad $30 \%$ po pierwszym podaniu leku. W obu badaniach toksyczność leczenia była niska, przy czym, co zaskakujące, praktycznie nie obserwowano ciężkich reakcji poinfuzyjnych. Wyniki tych prób klinicznych, a także innych podobnych doniesień, potwierdzają wysoką aktywność i dobrą tolerancję daratumumabu u chorych na AAL.

Oprócz metod chemioterapii i immunoterapii skierowanych przeciwko plazmocytom produkującym prekursory amyloidu od kilku lat dynamicznie rozwijają się również terapie, których celem są już wytworzone złogi amyloidu. Podczas Konferencji ASH w 2017 roku przedstawiono między innymi obiecujące wyniki badania I fazy, w ktorym oceniano aktywność jednego $z$ nowych przeciwciał mających prowadzić do resorpcji złogów amyloidu - CAEL-101 (mAb 11-1F4) (streszczenie 509). Zastosowanie leku u chorych, którzy osiągnęli wcześniej odpowiedź hematologiczną, prowadziło do szybkich odpowiedzi narządowych u części $z$ nich; CAEL-101 oraz pokrewne terapie budzą nadzieję na poprawę długości i jakości życia chorych, u których rozpoznania amyloidozy dokonano późno, w tym szczególnie pacjentów $z$ zaawansowaną kardiomiopatią amyloidową.

\section{Chłoniaki agresywne}

prof. dr hab. n. med. Grzegorz Nowakowski

Streszczenia nie nadesłano.

\section{Chłoniaki indolentne \\ dr n. med. Ewa Kalinka-Warzocha}

Podczas ostatniej konferencji ASH ukazały się wyniki kilku badań stanowiących kontynuację francuskiego badania PRIMA (The Primary RItuximab and MAintenance). Obejmowało ono nieleczonych chorych na chłoniaki grudkowe (FL, follicular lymphoma) $z$ dużą masą guza poddanych immunochemioterapii z zastosowaniem rytuksymabu (R). Zgodnie $z$ randomizacją stosowano $u$ nich trwające 2 lata leczenie podtrzymujące $\mathrm{R}$ ( 505 chorych) lub poddawano obserwacji (513 chorych). W pierwszym z doniesień Bachy i wsp. zaprezentowali nowy wskaźnik prognostyczny dla chorych na FL de novo objętych immunochemioterapią, tj. PRIMA Prognostic Index (streszczenie 413). Punktem końcowym do zbudowania takiego modelu było PFS w kohorcie 1135 chorych uczestniczących w badaniu PRIMA, leczonych w pierwszej linii chemioterapią $z \mathrm{R} \pm \mathrm{z}$ leczeniem podtrzymującym $\mathrm{R}$. By zbudować 
model, włączono następujące zmienne: wiek, płeć, stan sprawności, objawy ogólne, stopień zaawansowania, liczba zajętych lokalizacji węzłowych i pozawęzłowych, największy wymiar największej masy węzłowej, obecność wysięku lub ucisku związanego $z$ chłoniakiem, obecność krążących komórek chłoniaka, liczba płytek (PLT, platelets) we krwi obwodowej, stężenie albumin w surowicy, zajęcie szpiku kostnego, stężenie $\beta_{2}$-mikroglobuliny $\left(\beta_{2}-\mathrm{m}\right)$. Kohortę walidacyjną stanowiło 175 chorych $z$ badania FL2000 $z$ grupy leczonej R-chemioterapią $z$ interferonem (IFN) w połączeniu z 304 chorymi włączonymi do prospektywnego badania MER (Molecular Epidemiology Resource) na University of Iowa/Mayo Clinic Lymphoma; wszyscy leczeni $\mathrm{w}$ pierwszej linii immunochemioterapią. Ustalony w ten sposób wskaźnik prognostyczny nazwano PRIMA-PI (PRIMA - Prognostic Index). Umożliwia on identyfikację trzech grup ryzyka: wysokiego (stężenie $\beta_{2}-\mathrm{m}>3 \mathrm{mg} / \mathrm{l}$ ), niskiego (stężenie $\beta_{2}-\mathrm{m}$ $\leq 3 \mathrm{mg} / \mathrm{l}$ bez zajęcia szpiku kostnego) i pośredniego (stężenie $\beta_{2}-\mathrm{m} \leq 3 \mathrm{mg} / \mathrm{l}$ z zajęciem szpiku kostnego); PRIMA-PI miał wartość dyskryminującą dla 5-letniego PFS w grupach niskiego (69\%, 95-proc. przedział ufności [CI, confidence interval]: 64-73\%), pośredniego $(55 \%, 95 \%$ CI $49-60 \%)$ i wysokiego ryzyka $(37 \%, 95 \%$ CI $32-42 \%) z$ wartością p poniżej 0,0001. Wskániki FLIPI (Follicular Lymphoma International Prognostic Index) i PRIMA-PI podobnie pozwalają przewidzieć 5-letni OS, odpowiednio $93 \%$ w grupie niskiego/pośredniego ryzyka $\mathrm{w}$ porównaniu $\mathrm{z} 84 \% \mathrm{w}$ grupie wysokiego ryzyka według FLIPI oraz 93\% i $81 \%$ w odpowiednich grupach ryzyka według PRIMA-PI ( $p<0,0001$ dla każdego ze wskaźników). Stwierdzono ponadto, że PRIMA-PI jest lepszym czynnikiem predykcyjnym dla 24-miesięcznego wskaźnika PFS. Autorzy wnioskują, że PRIMA-PI jest zwalidowanym wskaźnikiem prognostycznym dla chorych na FL leczonych w pierwszej linii immunochemioterapią, ale — w odróżnieniu od FLIPI — opartym jedynie na dwóch parametrach (zajęcie szpiku kostnego i stężenie $\left.\beta_{2}-\mathrm{m}\right)$.

Salles i wsp. (streszczenie 486) poddali analizie wskaźniki przeżycia po okresie obserwacji o medianie 9 lat $\mathrm{u}$ chorych $\mathrm{w}$ badaniu PRIMA. Mediana PFS u obserwowanych chorych wyniosła 4,06 roku, a u leczonych $\mathrm{R}-10,49$ roku (log-rank, $\mathrm{p}<0,0001 ; \mathrm{HR}=0,61 ; 95 \%$ CI 0,52-0,73). Po 10 latach $51 \%$ chorych w grupie objętej leczeniem podtrzymującym R pozostawało wolnych od progresji, $\mathrm{w}$ porównaniu $z 35 \% \mathrm{w}$ grupie obserwowanej. Korzyść $z$ podtrzymującego leczenia $\mathrm{R}$ była istotna w każdej podgrupie zdefiniowanej według czynni- ków statyfikujących: wieku (punkt odcięcia 60 lat), płci, kategorii 3 według FLIPI, jakości odpowiedzi na leczenie indukujące (CR i odpowiedź częściowa [PR, partial response]), a także u chorych poddanych terapii według schematu R-CHOP (rytuksymab, cyklofosfamid, doksorubicyna, winkrystyna, prednizon) ( $\mathrm{HR}=0,57 ; 95 \%$ CI $0,47-0,70)$, natomiast $\mathrm{u}$ leczonych $\mathrm{R}$ obserwowano jedynie trend ( $\mathrm{HR}=0,75 ; 95 \% \mathrm{CI} 0,53-1,07) . \mathrm{W}$ analizie regresji Coxa stwierdzono, że leczenie podtrzymujące $\mathrm{R}$ jest niezależnym czynnikiem od wymienionych wyżej zmiennych (HR 0,60; 95\% CI 0,50-0,71). W chwili analizy zmarło 84 i 88 chorych, odpowiednio, w grupach obserwowanej oraz poddanej leczeniu podtrzymującemu - 38 i $39 \mathrm{z}$ powodu progresji chłoniaka, 24 i 6 chorych $z$ powodu innych nowotworów (w tym 7 i $2 \mathrm{w}$ związku $\mathrm{z}$ nowotworami hematologicznymi), 6 i 11 pacjentów $z$ powodu infekcji oraz 4 i 8 pacjentów $z$ powodu chorób układu sercowo-naczyniowego. Szacowany 10-letni OS wyniós $80 \%$ w obu grupach. We wnioskach autorzy podają, że strategia polegająca na uzyskaniu trwałej pierwszej remisji z leczeniem podtrzymującym $\mathrm{R}$ pozostaje wartościową opcją terapeutyczną.

Hill i wsp. (streszczenie 2779) oceniali skuteczność leczenia podtrzymującego R (RM, rituximab maintenance) $\mathrm{w}$ porównaniu $\mathrm{z}$ obserwacją po leczeniu pierwszej linii według schematu BR (bendamustyna, rytuksymab) u chorych na FL na podstawie danych z 13 ośrodków w Stanach Zjednoczonych; zebrano dane 640 chorych. Po medianie czasu obserwacji wynoszącej 36 miesięcy odnotowano 63 zgony $(9,8 \%)$, spośród których 26 nastąpiło $\mathrm{z}$ powodu chłoniaka, $12 \mathrm{z}$ powodu infekcji lub niewydolności wielonarządowej, 12 $z$ nieznanej przyczyny, $10 \mathrm{z}$ powodu nowotworu litego, $1 \mathrm{z}$ powodu zespołu mielodysplastycznego, $1 \mathrm{z}$ przyczyn sercowo-naczyniowych i także $1 \mathrm{z}$ powodu leukoencefalopatii wieloogniskowej. U 584 chorych zastosowano co najmniej 4 cykle BR; RM podawano częściej chorym odpowiadających na $B R$. Odsetki odpowiedzi wynosiły, odpowiednio, CR $-71 \%$ i PR $-28 \%$ u leczonych RM i $58 \%$ i $30 \%$ $\mathrm{u}$ poddanych obserwacji $(\mathrm{p}<0,001)$. Stwierdzono, że 3-letni PFS u chorych $z$ PR po BR wyniósł $80 \%$ w grupie leczonej RM i $44 \%$ w grupie odpowiadających na BR $(\mathrm{p}=0,002)$, a u chorych $z \mathrm{CR}$ po BR odpowiednio $86 \%$ i $80 \%(\mathrm{p}=0,54)$. U chorych $z$ PR/CR po terapii wedłuch schematu BR analiza wielowariancyjna potwierdziła wartość FLIPI jako czynnika prognostycznego względem PFS (HR 2,47; 95\% CI 1,43-4,28; $\mathrm{p}=0,001$ ) i OS (HR $5,47 ; 95 \%$ CI 1,81-16,53, $\mathrm{p}=0,003)$. Natomiast leczenie RM wiązało się z poprawą PFS u chorych 
w PR (HR 0,36; 95\% CI 0,18-0,71; p = 0,003), ale nie stwierdzono takiego związku u chorych w CR po BR (HR 0,80; 95\% CI 0,38-1,66; p = 0,55). Nie zaobserwowano związku między RM a OS. Autorzy podsumowują, że - biorąc pod uwagę wszelkie ograniczenia analizy retrospektywnej - powyższe dane sugerują, że chorzy w PR po indukcji BR i MR odnoszą korzyść w zakresie PFS, ale pozostaje to bez wpływu na OS, co jest spójne $z$ wynikami badania PRIMA.

Rummel i wsp. (streszczenie 483) przedstawili wyniki badania służącego porównaniu trwającego 2 lata leczenia podtrzymującego $\mathrm{R}\left(375 \mathrm{mg} / \mathrm{m}^{2}\right.$ co 2 miesiące) $z$ 4-letnim po indukcji 6 cyklami BR. Wyniki dotyczyły prospektywnego, randomizowanego badania III fazy prowadzonego wśród nieleczonych chorych na FL (badanie StiL [Study Group Indolent Lymphomas] NHL7-2008 MAINTAIN). Do badania włączono 612 chorych na FL, spośród których 555 oceniono w zakresie odpowiedzi na indukcję BR, uzyskując odpowiedź u 497 z nich (90\%), przy czym u 181 (33\%) stwierdzono CR. U 261 chorych doszło do zakończenia leczenia w czasie indukcji lub $\mathrm{w}$ czasie 2 pierwszych lat leczenia podtrzymującego R. Ostatecznie 351 chorych poddano randomizacji po 2 latach leczenia podtrzymującego do obserwacji lub kolejnych 2 lat podawania R. Mediana obserwacji wyniosła 36 miesięcy po randomizacji. Mediany PFS ani OS nie osiągnięto w żadnej $z$ badanych grup. Jednak nieistotnie lepsze PFS osiągnięto u chorych leczonych podtrzymująco 4 lata względem leczonych 2 lata (HR 0,63; 95\% CI 0,36-1,11). Nie stwierdzono różnic w zakresie OS. Jeden chory objęty randomizacją do 4-letniego leczenia podtrzymującego R zmarł wskutek leukoencefalopatii wieloogniskowej. Autorzy wnioskują, że trwające 4 lata leczenie podtrzymujące $\mathrm{R}$ wydaje się korzystniejsze niż trwające 2 lata. Jednak zaprezentowane dane nie zawierają wystarczających dowodów na poparcie tego wniosku.

Leczenie pierwszej linii u chorych na FL jest ciągle przedmiotem badań dążących uzyskaniu poprawy względem standardu. Na ostatniej Konferencji ASH zaprezentowano wyniki badania II fazy BIONIC, którego celem była ocena, czy dodanie do schematu BR bortezomibu (V) w fazie indukcji i lenalidomidu do $\mathrm{R} w$ fazie leczenia podtrzymującego poprawi wskaźniki skuteczności leczenia $\mathrm{u}$ chorych na FL wysokiego ryzyka (streszczenie 482). Do badania włączono 289 chorych. Stwierdzono, że dołączenie V do BR poprawia odsetki CR, ale nie przekłada się na PFS. Natomiast dołączenie lenalidomidu do R istotnie zwiększa toksyczność, a nie wpływa na PFS ani OS. Dlatego ani dodania
$\mathrm{V}$ do indukcji BR, ani dodania lenalidomidu do $\mathrm{R}$ nie zaleca się u chorych na FL wysokiego ryzyka.

Celem Casulo i wsp. (streszczenie 412) była ocena związku między FILIPI i innymi czynnikami wyjściowymi a wystąpieniem progresji lub zgonu po 24 miesiącach (POD24) oraz walidacja POD24 jako wczesnego klinicznego punktu końcowego u chorych na FL na podstawie analizy danych chorych uczestniczących w 13 badaniach klinicznych (przed i po wprowadzeniu R). Po 24 miesiącach od włączenia do badania doszło do progresji chłoniaka u 29\% chorych, a 2,5\% chorych zmarło bez progresji choroby. Chorzy żyjący bez progresji po 24 miesiącach byli młodsi, w lepszym stanie sprawności (PS, performance status), z mniejszym zaawansowaniem FL, $z$ niskim FLIPI oraz wyjściowo prawidłowymi stężeniami hemoglobiny i $\beta_{2}-\mathrm{m}$. W modelu wielowariancyjnej regresji logistycznej wykazano, że płeć męska (iloraz szans [OR, odds ratio] 1,35; 95\% CI 1,19-1,52; p < 0,01), PS co najmniej 2 (OR 1,85; CI 1,47-2,38; $\mathrm{p}<0,01$ ) i wysoki FLIPI (3-5) (OR 2,94; CI 2,38-3,57; p < 0,01) wiązały się ze zwiększonym ryzykiem progresji lub zgonu po 24 miesiącach. Podwyższone wyjściowe stężenie $\beta_{2}$-m ( $\left.\geq 3 \mathrm{mg} / \mathrm{l}\right)$ wiązało się także ze zwiększonym ryzykiem progresji lub zgonu po 24 miesiącach (OR 1,47; CI 1,25-1,75; p < 0,01). Potwierdzono także zależność między POD24 i OS (HR 5,24; CI 4,63-5,93; p < 0,01), niezależnie od wieku, płci czy FLIPI. Podobny związek potwierdzono również w odniesieniu do wyjściowego stężenia $\beta_{2}$-m. W ocenie autorów POD24 jest wczesnym klinicznym punktem końcowym identyfikującym chorych o złym rokowaniu i powinien znaleźć zastosowanie w prospektywnych badaniach klinicznych.

Nową koncepcją leczenia chorych na chłoniaki jest skojarzenie $\mathrm{R} z$ blokadą punktów kontroli odpowiedzi immunologicznej (ICI, immune checkpoint inhibitors). Korzystając $z$ takiej strategii, zaplanowano jednoośrodkowe badanie II fazy, obejmujące chorych na FL $z$ nawrotem choroby, którym podawano $\mathrm{R} z$ pembrolizumabem (przeciwciało monoklonalne przeciw programowanej śmierci komórki 1 - anty-PD-1 [anti-programmed cell death protein 1]). Nastoupil i wsp. przedstawili wyniki tego badania na ostatniej konferencji ASH (streszczenie 414). Włączono do niego 30 dorosłych chorych na FL (G1-3A), w dobrym PS, w nawrocie po co najmniej 1 linii leczenia, wrażliwych na $R$ (zdefiniowano to jako CR lub PR utrzymującą się $\geq 6$ miesięcy po zastosowaniu ostatniego schematu leczenia $z$ udziałem $R$ ). Chorzy otrzymywali $R$ $\left(375 \mathrm{mg} / \mathrm{m}^{2}\right)$ 1., 8., 15. i 22 . dnia 1 . cyklu $\mathrm{z}$ zastosowaniem pembrolizumabu ( $200 \mathrm{mg}$ ) co 3 tygodnie do 
16 cykli, począwszy od 2 . dnia 1 . cyklu. Głównym punktem końcowym był ORR zgodnie $z$ klasyfikacją Lugano. W chwili analizy spośród 30 chorych, u których rozpoczęto leczenie, u 10 je kontynuowano. Dwudziestu pięciu chorym co najmniej 8 razy podano pembrolizumab. Mediana wieku wyniosła 64 lata, $57 \%$ badanej grupy stanowili mężczyźni, $73 \%$ - osoby z PS wynoszącym $0,73 \%$ cechowało się pośrednim lub wysokim ryzykiem według FLIPI, u 50\% stwierdzono dużą masę guza według kryteriów GELF (Group d'Étude des Lymphomes Folliculaires). Działania niepożądane miały nieznaczne nasilenie, większość 1.-2. stopnia; działania niepożądane 3. stopnia obejmowały: nudności $(n=2)$, reakcje związane $z$ wlewem $(n=2)$, nadciśnienie tętnicze $(\mathrm{n}=1)$, aseptyczne zapalenie opon mózgowo-rdzeniowych $(\mathrm{n}=1)$. Działania niepożądane o podłożu immunologicznym obejmowały: biegunkę w stopniach $1 .(n=6)$ i 2 . $(\mathrm{n}=4)$, wysypkę w stopniach $1 .(\mathrm{n}=2)$ i $2 .(\mathrm{n}=2)$, zwiększoną w stopniu 1. aktywność aminotransferaz $(\mathrm{n}=4)$, zapalenie pęcherzyków płucnych $\mathrm{w}$ stopniu 2. $(\mathrm{n}=1)$, zapalenie trzustki 2 . stopnia $(\mathrm{n}=1)$ oraz niedoczynność tarczycy 1 . stopnia $(\mathrm{n}=1)$. $\mathrm{U} 25$ pacjentów poddanych ocenie ORR stwierdzono, że wynosi on $64 \%$ (CR u 12 chorych, PR u 4); odsetek CR wyniósł $48 \%$. Po obserwacji o medianie 11 miesięcy u $60 \%$ obserwowano utrzymującą się odpowiedź. Ekspresję liganda PD-1 (PD-L1) zbadano w 8 próbkach guza; stwierdzono dodatnią ekspresję PD-L1 na histiocytach we wszystkich 8 przypadkach, ale jedynie na 1-8\% komórkach chłoniaka u 5 chorych. Ekspresja PD-L1 nie wiązała się $z$ odpowiedzią na leczenie. Analizę sygnatury ekspresji genów w wyjściowych próbkach guza przeprowadzono metodą NanoString u 12 chorych i wykazała związek między obecnością wysokich poziomów wskaźnika genów efektorowych limfocytów T CD8+ a uzyskaniem CR. Autorzy wnioskują, że potwierdzono aktywność pembrolizumabu $\mathrm{w}$ skojarzeniu $\mathrm{z} \mathrm{R}$ u chorych $\mathrm{z}$ nawrotową postacią $\mathrm{FL}$, osiągając istotny odsetek CR. Analizy sygnatur eskpresji genowych mogą pomóc w identyfikacji potencjalnych biomarkerów o znaczeniu predykcyjnym, co wymaga dalszych badań.

\section{Chłoniak Hodgkina}

prof. dr hab. n. med. Tomasz Wróbel

Najważniejsze doniesienia dotyczące chłoniaka Hodgkina (HL, Hodgkin lymphoma), prezentowane podczas 59. Konferencji ASH w 2017 roku, dotyczyły postępu, jaki się dokonał w leczeniu za pomocą przeciwcial anty-CD 30 (BV, brentuximab vedotin) i anty-PD-1 (niwolumab i pembrolizumab). Przed- stawiono między innymi wyniki badania ECHELON-1 (Phase 3 Frontline Therapy Trial in Patients With Advanced Classical Hodgkin Lymphoma), $z$ jednoczesną publikacją w „New England Journal of Medicine", w którym porównywano skuteczność leczenia skojarzonego BV z chemioterapią według schematu AVD (adriamycyna, winblastyna, deksametazon) ze standardowym leczeniem zgodnie $z$ protokołem ABVD (adriamycyna, bleomycyna, winblastyna, deksametazon) u dotychczas nieleczonych chorych na zaawansowaną postać HL (N. Engl. J. Med. 2018; 378: 331-344). Do badania włączono łącznie 1334 chorych w III lub IV stadium zaawansowania. Pierwszorzędowym punktem końcowym był zmodyfikowany PFS (mPFS, modified PFS), liczony jako czas do progresji (TTP, time to progression), zgonu, dodatniego wyniku badania pozytonowej tomografii emisyjnej (PET, positron emission tomography) (3-5 wg skali Deaville) po 6. cyklu lub następnej linii chemioterapii; 2-letni mPFS wynosił odpowiednio $82,1 \% \mathrm{w}$ grupie leczonej BV-AVD i 77,2\% w grupie leczonej ABVD. Nie wykazano istotnych różnic w zakresie OS. W grupie leczonej immunochemioterapią obserwowano większą częstość neutropenii (58\%) i polineuropatii (67\%). Nieznacznie większa toksyczność płucna występowała u chorych leczonych ABVD 3\% w porównaniu z $1 \%$ wśród leczonych BV-AVD. U chorych leczonych BV-AVD bez pierwotnej profilaktyki z zastosowaniem czynnika stymulującego wzrost kolonii granulocytów (G-CSF, granulocyte colony-stimulating factor) częstość gorączki neutropenicznej sięgała $21 \%$. Badanie osiągnęło założony statystyczny punkt końcowy i amerykańska Agencja ds. Żywności i Leków (FDA, Food and Drug Administration) zaaprobowała leczenie skojarzone według schematu BV-AVD jako leczenie pierwszej linii chorych na zaawansowaną postać HL. Wydaje się jednak, że wyniki tego badania nie zmienią istotnie praktyki klinicznej, między innymi ze względu na ogromny koszt takiego zestawu leków przy relatywnie niewielkiej poprawie skuteczności. Należy podkreślić toksyczność terapii, która była porównywalna $z$ toksycznością schematu schematu BEACOPP (bleomycyna, etopozyd, adriamycyna, cyklofosfamid, winkrystyna, prokarbazyna, prednizon) w dawkach eskalowanych (BEACOPPesc, BEACOPP escalated) (neutropenia i gorączka neutropeniczna). Warto zwrócić uwagę, że w tym samym czasie opublikowano wyniki niemieckiego badania HD18 dotyczącego podobnej populacji chorych na HL (Lancet 2017; 390: 2790-2802). Badacze niemieccy wykazali, że u chorych $\mathrm{z}$ zaawansowanym HL leczonych BEACOPPesc $z$ negatywnym wyni- 
kiem PET2 (PET2-) zastosowanie łącznie jedynie 4 cykli pozwala na uzyskanie 5-letniego PFS w $92,2 \%$. W brytyjskim badaniu RATHL (Response Adapted Therapy in Advanced Hodgkin Lymphoma), $z$ wykorzystaniem wczesnej oceny PET, udało się uzyskać wyniki podobne jak w ECHELON-1, zmniejszając dawkę bleomycyny u chorych PET2(-) (N. Engl. J. Med. 2016; 374: 2419-2429).

Czy zatem rola BV w leczeniu pierwszej linii pozostanie ograniczona? Odmienny sposób postępowania $z$ sekwencyjnym podawaniem BV i AVD w leczeniu starszych chorych zaproponowali Evens i wsp.; 48 chorych powyżej 60 . roku życia $z$ rozpoznanym de novo $\mathrm{HL} \mathrm{w}$ stadium IIB-IV otrzymało 2 dawki BV, a następnie 6 cykli AVD. Całkowity odsetek odpowiedzi po BV wynosił $87 \%$, a CR $30 \%$, jednak po kolejnych 6 cyklach chemioterapii odsetek ORR wzrósł do $95 \%$, zaś CR - do $91 \%$. Działania niepożądane, głównie neutropenię, obserwowano u $42 \%$ chorych. Wyniki tego niewielkiego badania wskazują na wysoką skuteczność leczenia sekwencyjnego BV i AVD u chorych w starszym wieku (streszczenie 73).

Ciekawą obserwacją wykorzystującą synergistyczne działanie ibrutynibu i BV było badanie Chena i wsp. U chorych $z$ nawrotowym/opornym HL zastosowano te leki w skojarzeniu, uzyskując ORR $69 \%$, co jest wynikiem podobnym jak po podaniu BV w monoterapii. Jednak autorzy podkreślają znacząco wyższy odsetek CR, który wyniósł 46\%, oraz skuteczność tej kombinacji nawet u chorych opornych na BV (streszczenie 738).

Spośród doniesień dotyczących przeciwciał anty-PD-1 na uwagę zasługuje analiza subpopulacji pacjentów $z$ badania CheckMate 205, dotycząca skuteczności i bezpieczeństwa leczenia niwolumabem po stwierdzeniu progresji choroby (streszczenie 650). W związku ze specyficznym mechanizmem działania przeciwciał anty-PD-1 ocena odpowiedzi na leczenie tradycyjnymi metodami jest często nieadekwatna. W poprawce do protokołu badania dopuszczono możliwość kontynuacji leczenia niwolumabem chorych w dobrym stanie klinicznym, z powolną progresją lub w sytuacji korzyści klinicznej w ocenie lekarza. Mediana dalszego leczenia niwolumabem wynosiła 5 miesięcy. W tej grupie u $53 \%$ chorych obserwowano zmniejszenie masy guza, u $31 \%$ wynosiła ona więcej niż $25 \%$. Mediana czasu do następnej terapii wynosiła 8,8 miesiąca, a u osób z progresją choroby, którzy nie kontynuowali terapii, jedynie 1,5 miesiąca. Wyniki tego badania wskazują, że mimo stwierdzenia progresji według kryteriów Chesona duża grupa pacjentów odnosi korzyść $z$ kontynuacji immunoterapii. Nowe, zaktualizowane kryteria odpowiedzi pozwolą na lepszą ocenę efektywności terapii przeciwciałami anty-PD-1.

Problem leczenia chorych $z$ niedostateczną odpowiedzią po leczeniu niwolumabem lub pembrolizumabem przedstawiła grupa francuska (streszczenie 652). Rossi i wsp. przedstawili wyniki leczenia 30 chorych $z$ oporną/nawrotową postacią HL (mediana linii leczenia wynosiła 6 , w tym auto-HSCT i BV), którzy otrzymywali przeciwciało anty-PD-1, nie uzyskując poprawy. Po zakończeniu leczenia przeciwciałem 19 chorych poddano chemioterapii, a u 11 kontynuowano immunoterapię anty-PD-1 w skojarzeniu $z$ chemioterapią. Stosowano między innymi winorelbinę, winblastynę, gemcytabinę, bendamustynę i BV. W pierwszej grupie uzyskano CR $32 \%$, w 5 przypadkach - PR (26\%), u 1 pacjenta - stabilizację choroby (SD, stable disease) (5\%), a 6 - progresję choroby (PD, progressive disease) (32\%). W grupie drugiej osiągnięto CR $45 \%$, u 5 - PR (45\%), a u 1 - SD (10\%). Wyniki te wskazywałyby na synergistyczny efekt immuno- i chemioterapii. Wymaga to jednak sprawdzenia w prospektywnych badaniach.

\section{Przewlekła białaczka limfocytowa \\ dr hab. n. med. Iwona Hus}

W ostatnich latach obserwuje się istotny postęp w leczeniu chorych na przewlekłą białaczkę limfocytową (CLL, chronic lymphocytic leukemia), zwłaszcza od czasu wprowadzenia do terapii nowych cząsteczek, takich jak glikozylowane przeciwciało monoklonalne anty-CD20 (obinutuzumab), oraz nowych terapii celowanych - ibrutynibu, idelalizybu (inhibitory receptora limfocytu B [BCR, $B$-cell receptor]) i wenetoklaksu (inhibitor BCL-2). Przewlekła białaczka limfocytowa pozostaje jednak chorobą nieuleczalną, a rokowanie $\mathrm{u}$ chorych $\mathrm{z}$ delecją 17p/mutacją TP53, mimo znacznej poprawy uzyskanej dzięki lekom drobnocząsteczkowym, jest nadal gorsze niż u pozostałych chorych. Ponadto nowe terapie celowane muszą być stosowane w sposób ciągły i u większości chorych pozwalają uzyskać jedynie PR. $Z$ powyższych względów celem prowadzonych obecnie badań klinicznych jest opracowanie schematów leczenia skojarzonego $z$ wykorzystaniem nowych cząsteczek, które pozwolą uzyskać lepszą jakość odpowiedzi przy określonym czasie leczenia. Większość doniesień na temat CLL prezentowanych $\mathrm{w}$ trakcie sesji ustnych ostatniej konferencji ASH dotyczyła wstępnych wyników badań klinicznych I lub II fazy $z$ zastosowaniem nowych cząsteczek stosowanych w ramach schematów skojarzonych 
z przeciwciałami monoklonalnymi anty-CD20 i/lub chemioterapią. Pierwszorzędowym punktem końcowym w wielu $z$ tych badań było uzyskanie całkowitej odpowiedzi, $z$ negatywizacją MRD (CR MRD-). Zaprezentowane wyniki wskazują, że leczenie pozwala uzyskać wysokie odsetki odpowiedzi; największe odsetki eradykacji MRD uzyskano $\mathrm{u}$ chorych leczonych wenetoklaksem i obinutuzumabem - 100\% (krew obwodowa) i 75\% (szpik kostny) (streszczenie 430), a największe odsetki CR MRD- obserwowano u chorych leczonych zgodnie ze schematami: ibrutynib i FCR (fludarabina, cyklofosfamid, rytuksymab) - 57\% (streszczenie 496) oraz ibrutynib i FCG (fludarabina, cyklofosfamid, obinutuzumab) - 75\% (streszczenie 495). W jednoośrodkowym badaniu randomizowanym wykazano, że zastosowanie leczenia skojarzonego ibrutynibem i wenetoklaksem nie przynosi istotnej korzyści terapeutycznej w odniesieniu do czasu do TTP choroby (pierwszorzędowy punkt końcowy) w porównaniu $z$ monoterapią ibrutynibem (streszczenie 427). W trakcie sesji LBA przedstawiono wyniki wieloośrodkowego randomizowanego badania III fazy MURANO (A Study to Evaluate the Benefit of Venetoclax Plus Rituximab Compared With Bendamustine Plus Rituximab in Participants With Relapsed or Refractory Chronic Lymphocytic Leukemia [CLL]), w którym udowodniono większą skuteczność schematu wenetoklaks $z \mathrm{R}$ niż schematu BR, w odniesieniu do PFS (pierwszorzędowy punkt końcowy) - 84,9\% w porównaniu z $36,3 \%$, ORR $-93,3 \%$ w porównaniu z $67,7 \%, \mathrm{CR}-26,8 \%$ w porównaniu $z 8,2 \%$ oraz eradykacji MRD $-83,5 \%$ w porównaniu z 23,1\% (LBA-2).

\section{Zakażenia w hematologii i transplantologii dr hab. n. med. Lidia Gil}

Zakażenia należą do najczęstszych i najpoważniejszych powikłań u chorych leczonych $z$ powodu nowotworów hematologicznych. Sprzyjają temu zarówno zaburzenia w układzie odporności towarzyszące tym chorobom, jak i ich leczenie, zwykle ukierunkowane na układ immunologiczny. Wprowadzenie nowoczesnych terapii w leczeniu chorych na nowotwory układu chłonnego wpłynęły na wydłużenie życia chorych, ale także na profil infekcji występujący w tej grupie, co ujawniły analizy real life. Najnowsze badania przedstawione podczas konferencji ASH w 2017 roku wskazują, że podstawą najwłaściwszej strategii jest zapobieganie zakażeniom poprzez: a) identyfikację pacjentów $z$ grup ryzyka; b) profilaktykę farmakologiczną u wybranych chorych; c) szczepienia ochronne, ale także zmiany organizacyjne związane $z$ opieką nad pacjentami w trakcie leczenia onkohematologicznego. U chorych na CLL od wielu lat dominują zakażenia o etiologii bakteryjnej, jednak zwraca uwagę zwiększenie w ostatnim czasie liczby zakażeń spowodowanych przez bakterie Gram(-) (streszczenie 3461). Ważne obserwacje przedstawiono w odniesieniu do pacjentów z CLL leczonych ibrutynibem, u których obserwuje się zwiększone ryzyko wystąpienia grzybiczych zakażeń oportunistycznych, zwłaszcza inwazyjnej aspergilozy obarczonej wysoką śmiertelnością (streszczenia 830, 3460, 4323). W procesie leczenia pacjentów z PCM powikłania infekcyjne występują przede wszystkim w pierwszych kilku tygodniach od rozpoznania oraz $\mathrm{w}$ okresie progresji choroby i są związane $z$ zaburzeniami immunologicznymi w przebiegu choroby i leczeniem (streszczenia 1875, 3148). Dominują zakażenia bakteryjne i wirusowe, którym jednak można w dużym odsetku zapobiegać, stosując profilaktykę przeciwbakteryjną (lewofloksacyna), przeciwwirusową (acyklowir lub walacyklowir) i szczepienia, zwłaszcza przeciwko pneumokokom (streszczenia 903, 1871, 2117). Najwyższe ryzyko zakażeń dotyczy chorych poddawanych przeszczepieniu krwiotwórczych komórek macierzystych (HSCT, hematopoietic stem cell transplantation). Mimo niewątpliwego postępu w zakresie leczenia wspomagającego powikłania infekcyjne stanowią istotną przyczynę śmiertelności w tej grupie chorych. Leczenie ambulatoryjne zakażeń w przeznaczonych do tego ośrodkach, a także prowadzenie zabiegów transplantacji $\mathrm{w}$ domu obniża ryzyko zakażeń i śmiertelności $z$ tego powodu, a ponadto wpływa korzystnie na jakość życia leczonych pacjentów i zmniejsza koszty leczenia (streszczenia 533, 745). Takie postępowanie wpływa również korzystnie na mikrobiom jelitowy, którego skład ulega zaburzeniom w procesie leczenia $z$ zastosowaniem HSCT, rzutując na jego wyniki (streszczenie 750). Do najczęstszych i najpoważniejszych powikłań infekcyjnych po HSCT należy infekcja wirusem cytomegalii (CMV, cytomegalovirus), obserwowana również po transplantacjach haploidentycznych z zastosowaniem cyklofosfamidu (streszczenie 664). U pacjentów $z$ oporną na farmakoterapię postacią infekcji i choroby CMV skuteczne i bezpieczne jest stosowanie immunoterapii $z$ wykorzystaniem limfocytów T cytotoksycznych CMV-specyficznych pochodzących od dawców lub $z$ banków komórek. Opublikowane podczas ostatniej Konferencji ASH wyniki badania III fazy dotyczącego profilaktyki CMV potwierdzają skuteczność letermowiru w tej strategii (streszczenia 747, 4484). 
Przeszczepienie krwiotwórczych

komórek macierzystych

w nowotworach układu krwiotwórczego

dr n. med. Kazimierz Hałaburda

Wśród wielu interesujących doniesień przedstawionych w trakcie ostatniej Konferencji ASH szczególnie istotne dotyczyły sposobu przygotowania chorych do przeszczepienia allogenicznych krwiotwórczych komórek macierzystych (allo-HSCT, allogeneic hematopoietic stem cell transplantation). W pierwszej z analiz, przedstawionej przez Sora i wsp. (streszczenie 909), porównywano retrospektywnie wyniki allo-HSCT u chorych po kondycjonowaniu BuFlu (busulfan dożylnie [i.v., intravenous] $12,8 \mathrm{mg} / \mathrm{kg} \mathrm{mc}$., fludarabina $160 \mathrm{mg} / \mathrm{m}^{2}$ przezskórnie [p.c., percutaneous]) oraz TBF (busulfan i.v. 9,6 mg/kg mc., tiotepa $10 \mathrm{mg} / \mathrm{kg} \mathrm{mc}$, fludarabina $150 \mathrm{mg} / \mathrm{m}^{2}$ ). Oceniono łącznie 205 chorych (78 leczonych BuFlu i 127 leczonych TBF) $\mathrm{w}$ wieku 17-78 lat (mediana 53) $\mathrm{z}$ rozpoznaniem ostrej białaczki szpikowej (AML, acute myeloid leukemia) lub zespołu mielodysplastycznego (MDS, myelodysplastic syndrome) typu niedokrwistości opornej $z$ nadmiarem blastów (RAEB, refractory anemia with excess of blasts) poddanych przeszczepieniu w okresie remisji hematologicznej (CR1 lub CR2, < $5 \%$ blastów w szpiku) w latach 2008-2017 w 5 ośrodkach włoskich. W profilaktyce choroby przeszczep przeciw gospodarzowi (GvHD, graft versus host disease) stosowano schematy oparte na cyklosporynie, $z$ dodatkiem globuliny antytymocytowej (ATG, antithymocyte globulin) $\mathrm{w}$ przypadku dawców niespokrewnionych lub cyklofosfamidu w przypadku transplantacji od dawców haploidentycznych. Grupy poddane leczeniu BuFlu i TBF różniły się istotnie pod względem rodzaju dawcy; odpowiednio $4 \%$ oraz $72 \%$ transplantacji przeprowadzono od dawców haploidentycznych. Końcowym punktem oceny było 5-letnie prawdopodobieństwo przeżycia. W grupie leczonej BuFlu wyniosło ono $41 \%$, natomiast $\mathrm{w}$ grupie leczonej TBF $-82 \%$ $(\mathrm{p}=0,0000)$. Stwierdzono istotnie mniejszą śmiertelność związaną $z$ nawrotem oraz śmiertelność związaną z leczeniem (TRM, treatment-related mortality) w grupie leczonej TBF niż poddanej terapii BuFlu (odpowiednio 9\% i 33\%; $\mathrm{p}=0,008$ oraz $9 \%$ i $25 \% ; p=0,007)$. W ocenie grup leczonych BuFlu i TBF po wyłączeniu chorych poddanych transplantacjom haploidentycznym prawdopodobieństwo 5-letniego przeżycia wyniosło odpowiednio $51 \%$ i $82 \%(\mathrm{p}=0,000)$. Według autorów kondycjonowanie TBF w porównaniu $z$ BuFlu cechuje się istotnie zmniejszoną toksycznością i prowadzi do mniejszej częstości nawrotów, co skutkuje statystycznie lepszym przeżyciem chorych.
W kolejnym ważnym doniesieniu (streszczenie 521) przedstawiono wyniki randomizowanego badania klinicznego służącego porównaniu kondycjonowania o obniżonej intensywności treosulfanem i fludarabiną (Treo $30 \mathrm{mg} / \mathrm{kg} \mathrm{mc.,} \mathrm{Flu} 150 \mathrm{mg} / \mathrm{m}^{2}$ ) $z$ busulfanem i fludarabiną ( $\mathrm{Bu} 6,4 \mathrm{mg} / \mathrm{kg} \mathrm{mc}$., Flu $150 \mathrm{mg} / \mathrm{m}^{2}$ ). Chorych objęto randomizacją w stosunku 1:1. Pierwszorzędowym celem badania było 2-letnie przeżycie bez zdarzeń niepożądanych (EFS, event-free survival) określonych jako zgon, nawrót lub niewydolność przeszczepu. Drugorzędowymi celami były OS oraz skumulowana częstość nawrotów (CIR, cumulative index of relapse). Do badania włączono 476 chorych $z$ rozpoznaniem AML w okresie CR ( $<5 \%$ blastów w szpiku) lub MDS ( $<20 \%$ blastów w szpiku), w wieku co najmniej 50 lat lub ze wskaźnikiem chorób dodatkowych (HCT-CI, Hematopoietic Cell Transplant - Comorbidity Index) powyżej 2. Mediana wieku wyniosła 60 lat (94\% osób w wieku $\geq 50$ lat), $64 \%$ stanowili chorzy na AML, a $76 \%$ transplantacji przeprowadzono od dawców niespokrewnionych. W ocenie końcowej stwierdzono EFS wynoszące $64 \%$ w porównaniu z $50,4 \%(\mathrm{p}=0,000016)$, OS $72,5 \%$ w porównaniu $\mathrm{z} 56,4 \%(\mathrm{p}=0,0082)$ oraz TRM $11,3 \% \mathrm{w}$ porównaniu $z 28,2 \%(p=0,02)$ odpowiednio dla leczenia TreoFlu i BuFlu. Nie stwierdzono istotnie różnych częstości nawrotów w obu grupach. W konkluzji autorzy podkreślili wyraźną przewagę Treo nad $\mathrm{Bu} \mathrm{w}$ schemacie o obniżonej intensywności w badanej populacji chorych, szczególnie pod względem TRM, co w konsekwencji pozwoliło na uzyskanie dłuższego przeżycia.

Następnym doniesieniem dotyczącym kondycjonowania było przedstawienie wyników badania randomizowanego prowadzonego w Chinach (streszczenie 597), w którym porównywano zintensyfikowany schemat IdaBuCy (idarubicyna $60 \mathrm{mg} / \mathrm{m}^{2}$, busulfan i.v. $12,8 \mathrm{mg} / \mathrm{kg}$ mc., cyklofosfamid $120 \mathrm{mg} / \mathrm{kg} \mathrm{mc}$.) z klasycznym BuCy (busulfan i.v. $12,8 \mathrm{mg} / \mathrm{kg}$ mc., cyklofosfamid $120 \mathrm{mg} / \mathrm{kg} \mathrm{mc}$.). W profilaktyce GvHD stosowano cyklosporynę (CsA) metotreksat (MtX), mykofenolan mofetilu (MMF) oraz ATG w transplantacjach od dawców niespokrewnionych. Do badania włączono 118 chorych na AML wysokiego ryzyka (niekorzystne ryzyko cytogenetyczno-molekularne, brak remisji po pierwszej indukcji, > CR1, wtórna AML), spośród których 61 przydzielono do grupy leczonej IdaBuCy, a 57 do grupy porównawczej. Grupy były zrównoważone pod względem charakterystyki pacjentów oraz rodzaju transplantacji. Mediana wieku chorych wyniosła 46 lat, a mediana czasu obserwacji chorych żyjących - 19 miesięcy od 
transplantacji. Prawdopodobieństwa OS, przeżycia wolnego od choroby (DFS, disease-free survival), TRM oraz częstości nawrotu w okresie 2-letnim w grupach leczonych IdaBuCy oraz ByCy wyniosły, odpowiednio, $75,2 \% \mathrm{w}$ porównaniu $\mathrm{z} 51,2 \%$ $(p=0,012), 74,9 \%$ w porównaniu $50,1 \%(p=0,01)$, $12,7 \%$ w porównaniu $28,6 \%(\mathrm{p}=0,186)$ oraz $13,7 \%$ w porównaniu $28,1 \%(\mathrm{p}=0,030)$. Podsumowując wyniki badania, autorzy podkreślali korzystny efekt intensyfikacji standardowego schematu kondycjonowania poprzez zastosowanie Ida. Dzięki zmniejszeniu częstości nawrotów w populacji chorych na AML wysokiego ryzyka uzyskano istotną poprawę przeżycia, bez narażenia chorych na zwiększoną TRM.

W kolejnym doniesieniu (streszczenie 2050) przedstawiono wyniki retrospektywnej analizy jednoośrodkowej służącej porównaniu wyników transplantacji u chorych na nowotwory układu krwiotwórczego po kondycjonowaniu mieloablacyjnym (MAC, myeloablative conditioning) lub o obniżonej intensywności (RIC, reduced-intensive conditioning). Do analizy włączono 232 chorych na AML $(\mathrm{n}=170)$ lub MDS $(\mathrm{n}=60)$ cechujących się niskim lub pośrednim ryzykiem związanym $z$ chorobą podstawową. Mediana wieku chorych wyniosła 55 lat (18-75), a mediana czasu obserwacji -73 miesiące. Kondycjonowanie o obniżonej intensywności zastosowano u $42 \%$ chorych, natomiast MAC u $58 \%$ chorych (w tym oparte na napromienianiu całego ciała [TBI, total-body irradiation] u 11\%). Transplantacje przeprowadzono od dawców rodzinnych $(53 \%$, w tym haploidentyczne w 22\%) lub niespokrewnionych (47\%), a źródłem przeszczepu w $79 \%$ przypadków była krew obwodowa. U $49 \%$ chorych stwierdzano HCT-CI wynoszący 3 lub więcej. Grupy poddane MAC i RIC były porównywalne pod względem charakterystyki chorych oraz transplantacji. Jedyną różnicą było częstsze zastosowanie MtX w profilaktyce GvHD $\mathrm{w}$ grupie poddanej MAC. Przedstawiono 3-letnie prawdopodobieństwa OS, DFS, CIR oraz śmiertelności niezwiązanej $z$ nawrotem (NRM, non-relapse mortality) dla grup poddanych MAC oraz RIC. Wyniosty one, odpowiednio, 69\% w porównaniu z $57 \%(\mathrm{p}=0,001), 65 \% \mathrm{w}$ porównaniu z $51 \%$ $(\mathrm{p}=0,003), 17 \% \mathrm{w}$ porównaniu $\mathrm{z} 32 \%(\mathrm{p}=0,01)$ oraz $19 \%$ w porównaniu $z 17 \%(\mathrm{p}=0,4)$. Podsumowując wyniki analizy, autorzy podkreślili korzystny efekt MAC w porównaniu $\mathrm{z}$ RIC $\mathrm{u}$ chorych na AML i MDS cechujących się niskim i pośrednim ryzykiem. Stosując MAC, można w tej grupie chorych osiągnąć lepsze OS i DFS dzięki obniżeniu ryzyka nawrotów, bez jednoczesnego podwyższenia TRM.
Autorzy przeprowadzili identyczną analizę w grupie 247 chorych na AML i MDS obarczonych wysokim lub bardzo wysokim ryzykiem, w której nie stwierdzono korzystnego wpływu MAC na żaden $z$ badanych punktów końcowych.

Następna interesująca analiza dotyczyła porównania MAC i RIC u chorych na AML wtórne do wcześniejszych MDS lub nowotworów mieloproliferacyjnych (MPN, myeloproliferative neoplasms) (streszczenie 907), przeprowadzona przez EBMT (European Blood and Marrow Transplantation). Oceniano wyniki transplantacji przeprowadzonych u 811 chorych w latach 2000-2016. Przeszczepienia od zgodnych dawców rodzinnych stanowiły $42,4 \%$, natomiast od niespokrewnionych $57,6 \%$. Mediana czasu od rozpoznania wtórnej AML do transplantacj wyniosła 137 dni. Kondycjonowanie mieloablacyjne zastosowano u 326 chorych $(40,2 \%)$, natomiast niemieloablacyjne u 485 (59,8\%). U 401 chorych $(49,5 \%)$ transplantację przeprowadzono w okresie CR1, natomiast u $367(45,3 \%)$ bez osiągnięcia CR. U starszych chorych częściej stosowano RIC ( $<<0,001$ ); poza tym grupy poddane RIC i MAC były porównywalne pod względem ryzyka cytogenetyczno-molekularnego choroby oraz stanu remisji przed transplantacją. Wyniki przedstawione przez autorów wskazują na korzystny efekt MAC $\mathrm{w}$ porównaniu $z$ RIC $\mathrm{w}$ stosunku do wszystkich badanych punktów końcowych u chorych poddawanych transplantacji z powodu wtórnej AML; 3-letnie prawdopodobieństwa OS, stanu wolnego od białaczki (LFS, leukemia-free state), CIR i NRM w przypadku MAC w odniesieniu do RIC wyniosły, odpowiednio, $44 \% \mathrm{w}$ porównaniu $\mathrm{z} 38 \%$; $\mathrm{p}=0,041$, $38 \% \mathrm{w}$ porównaniu $\mathrm{z} 31 \%$; $\mathrm{p}=0,032,37 \% \mathrm{w}$ porównaniu $\mathrm{z} 45 \% ; \mathrm{p}=0,029$ oraz $25 \% \mathrm{w}$ porównaniu $z 25 \% ; p=0,959$.

Kolejne $z$ ważnych doniesień dotyczyło zwiększenia dawki TBI u chorych poddawanych allo-HSCT po tak zwanym minikondycjonowaniu, złożonym z Flu i TBI (streszczenie 908). Szczególnie w MDS i MPN zastosowanie standardowego schematu Flu w dawce $90-120 \mathrm{mg} / \mathrm{m}^{2}$ i TBI w dawce $200 \mathrm{cGy}$ wiąże się $z$ wysokim odsetkiem nawrotów lub braku wszczepienia. Autorzy badania zwiększali dawkę TBI do 300, 400 oraz 450 cGy w celu zmniejszenia odsetka braku wszczepienia do mniej niz 10\%. Chorych (wiek > 50 lat i/lub HCT$-\mathrm{CI} \geq 3$ ) $\mathrm{z}$ rozpoznaniem MDS/MPN podzielono na dwie grupy — niskiego (36 pacjentów) i wysokiego (41 pacjentów) ryzyka nawrotu. Założony cel badania $\mathrm{w}$ grupie niskiego ryzyka osiągnięto po pierwszym zwiększeniu dawki TBI (do 300 cGy). W grupie wysokiego ryzyka dopiero eskalacja 
dawki TBI do 450 cGy pozwoliła na osiągnięcie założonego celu badania i zmniejszenie odsetka nawrotów. Jednocześnie jednak obserwowano $\mathrm{w}$ tej grupie istotny wzrost śmiertelności związanej $z$ procedurą transplantacji. W konkluzji autorzy podkreślili konieczność zwiększania dawki TBI do 450 cGy u chorych na MDS/MPN wysokiego ryzyka poddanych kondycjonowaniu według schematu FluTBI, przy jednoczesnym opracowaniu schematów postępowania służących ograniczeniu TRM. W przypadku chorych na MDS/MPN niskiego ryzyka za optymalną autorzy uznali dawkę TBI wynosząca $300 \mathrm{cGy}$ w połączeniu z Flu.

W podsumowaniu należy podkreślić, że podczas 59. Konferencji ASH zaprezentowano więcej doniesień dotyczących transplantacji w nowotworach układu krwiotwórczego niż na każdej $z$ poprzednich konferencji przez kilka minionych lat. Wśród analiz i prezentacji $z$ ostatniej konferencji dał się zauważyć trend ponownego zainteresowania MAC lub wręcz kondycjonowaniem eskalowanym. Przedstawione wyniki wydają się potwierdzać słuszność takiego postępowania w wybranych grupach chorych.

\section{Mechanizmy patogenetyczne \\ i cele terapeutyczne \\ w nowotworach układu krwiotwórczego \\ dr n. med. Emilia Białopiotrowicz}

Ostrą białaczkę szpikową charakteryzuje znaczna heterogenność molekularna, co przekłada się na różne rezultaty kliniczne. Choć remisja kliniczna po zastosowaniu standardowej chemioterapii jest obserwowana u $70 \%$ nowo zdiagnozowanych chorych, to utrzymuje się ona jedynie u $35 \%$ chorych do 60. roku życia i u $15 \%$ chorych powyżej tej granicy wieku. Dlatego istotną kwestią poruszaną na konferencji ASH w 2017 roku było zrozumienie przyczyn pierwotnej oraz nabytej oporności w AML. Podobnie jak w przypadku prawidłowej hematopoezy choroba ta charakteryzuje się hierarchiczną organizacją komórkową. Zgodnie z wynikami ostatnich badań przyjmuje się istnienie dwóch modeli nawrotu AML ze względu na pochodzenie (Slush i wsp., Nature 2017). W pierwszym modelu (relapse from primitive origin) za nawrót choroby odpowiada nieliczna frakcja białaczkowych komórek macierzystych (LSC, leukemic stem cells) cechujących się prymitywnym fenotypem i dużym potencjałem do samoodnowy. Model ten wyróżnia złożona hierarchiczna organizacja komórkowa. $\mathrm{W}$ drugim modelu (relapse from committed origin) nawrót choroby następuje wskutek przetrwania po zastosowanej chemioterapii dość licznej i bardziej zróżnicowanej fenotypowo subpopulacji komórek blastycznych CD33+. Model ten charakteryzuje płytka hierarchiczna organizacja komórkowa. W leczeniu przypadków zaliczanych do drugiego modelu szczególnie skuteczna mogłaby się okazać terapia z zastosowaniem przeciwcial anty-CD33 (Slush i wsp., Nature 2017). Wiele doniesień przedstawionych na konferencji ASH w 2017 roku dotyczyło badań poświęconych potencjalnym strategiom terapeutycznym skierowanym przeciw LSC. Hinge i wsp. (streszczenie 633) przedstawili wyniki badań wskazujące, że rozmieszczenie mitochondriów w komórce macierzystej ma decydujący wpływ na przeprowadzenie podziału komórkowego w taki sposób, aby nowo powstała komórka zachowała zdolność do samoodnowy. Dlatego rola mitochondriów nie ogranicza się jedynie do zaopatrywania komórki w energię, ale również decydują o jej tożsamości. Powyższy wniosek potwierdzają badania Jeyaraju'a i wsp. (streszczenie 881). Większość białek mitochondrialnych jest kodowana przez geny jądrowe i musi zostać przetransportowana $z$ cytozolu do mitochondrium za pośrednictwem specjalnego kompleksu białkowego (MIA, mitochondrial inter-membrane space assembly) zlokalizowanego $\mathrm{w}$ mitochondrialnej przestrzeni międzybłonowej. Zaburzenie funkcjonowania kompleksu MIA przy użyciu inhibitora MitoBloCK-6 nie wpływa na zdolności metaboliczne mitochondriów, ale zmienia ich morfologię, co prowadzi do różnicowania zarówno komórek AML, jak i LSC.

Jedną $z$ cech wyróżniających LSC jest ich wysoka aktywność transkrypcyjna regulowana przez tak zwane superenhancery - rejony genomu, w których znajdują się liczne miejsca wiązania czynników transkrypcyjnych. Superenhancery decydują o ekspresji genów kluczowych dla utrzymania tożsamości komórki. Ben-Neriah i wsp. (streszczenie 812) przedstawili na konferencji ASH w 2017 roku wyniki dotyczące efektu działania dualnych inhibitorów skierowanych jednocześnie przeciwko kinazom CKI $\alpha$ (casein kinase I isoform alpha) oraz czynnikowi elongacji transkrypcji $\mathrm{P}-\mathrm{TEFb}$ (positive transcription elongation factor $b$ ). Jak wykazano we wcześniejszych badaniach, inhibitory CKI $\alpha$ powodują apoptozę komórek AML na drodze zależnej od P53, ale nie są efektywne w usuwaniu LSC. Tymczasem już krótkotrwała inkubacja $z$ dualnymi inhibitorami CKI $\alpha / \mathrm{P}-\mathrm{TEFb}$ (10 min w przypadku eksperymentów in vitro oraz $2 \mathrm{~h}$ w przypadku eksperymentów in vivo) powodowała zahamowanie aktywności superenhancerów i w konsekwencji apoptozę LSC w ciągu $24 \mathrm{~h}$, bez wpływu na żywotność prawidłowych komórek 
krwiotwórczych. Zaletą dualnych inhibitorów $\mathrm{CKI} \alpha / \mathrm{P}-\mathrm{TEFb}$ jest ich szybki mechanizm działania, co minimalizuje szanse nabycia oporności przez LSC.

Klonalna hematopoeza o nieokreślonym potencjale (CHIP, clonal hematopoiesis of indeterminate potential) występuje u $10 \%$ osób zdrowych po 70. roku życia. Zjawisko to polega na pojawieniu się wśród komórek krwiotwórczych subklonu, który dzięki nabyciu pewnych mutacji somatycznych zyskuje przewagę liczebną nad pozostałymi subpopulacjami komórek. Najczęstsze mutacje występujące w CHIP obejmują geny regulatorów epigenetycznych, DNMT3A, TET2 i ASXL1. $\mathrm{W}$ ostatnich latach przeprowadzono intensywne badania w celu wyjaśnienia, czy CHIP $z$ udziałem mutacji w tych genach ma znaczenie prognostyczne w AML. Odpowiedzi na to pytanie dostarczają badania Abelson i wsp. (streszczenie 471). Przedstawione wyniki wskazują, że klonalna ekspansja prowadząca do rozwoju AML różni się znacząco od zjawiska CHIP, a mutacje w szczególności predysponujące do AML dotyczą genów spliceosomu, czyli kompleksu odpowiedzialnego za dojrzewanie matrycowego RNA. Podobne badania przeprowadzili Desai i wsp. (streszczenie 408). Rezultaty ich analiz wskazały, że wykrycie mutacji w genach IDH2, TP53 i RUNX1 u osób zdrowych było równoznaczne $z$ rozpoznaniem AML u tych samych osób kilka lat później. $Z$ kolei mutacje w genach DNMT3A, TET2 i ASXL1/2 mimo że występowały $\mathrm{z}$ najwyższą częstością $\mathrm{w}$ badanej populacji, to nie miały żadnego znaczenia predykcyjnego. Dlatego uważa się, że wysoka częstość mutacji DNMT3A, TET2 i ASXL1/2 w CHIP jest raczej wynikiem próby uzyskania większej plastyczności transkrypcyjnej przez starzejące się komórki macierzyste szpiku.

Regulatory epigenetyczne poprzez wpływ na strukturę chromatyny kontrolują poziom ekspresji wielu genów, których produkty są zaangażowane w różne szlaki metaboliczne. Dlatego istnieje ważny związek między zmianami epigenetycznymi a metabolizmem komórkowym. Na związek ten wskazały liczne doniesienia przedstawione na konferencji ASH w 2017 roku. Na przykład Yang i Jiang (streszczenie 772 ) wykazali, że $z$ jednej strony wyłączenie białka regulującego metylację histonów Dpy30 zaburza proces fosforylacji oksydacyjnej, a w konsekwencji obniża potencjał energetyczny komórki krwiotwórczej. $Z$ drugiej strony metabolity komórkowe istotnie wpływają na zmiany epigenetyczne; LSC charakteryzują się nadekspresją enzymu BCAT1, który pośredniczy w metabolizmie aminokwasów rozgałęzionych, wykorzystując $\alpha$-ketoglutaran jako substrat. Nadekspresja BCAT1 w komórkach LSC powoduje nadmierną metylację DNA (wykład prof. Andreasa Trumppa: Friday scientific workshop on myeloid development).

Podsumowując, jednym $z$ kluczowych celów najbliższych lat będzie opracowanie strategii terapeutycznej, która pozwoli na całkowitą eliminację LSC. Potencjalny lek powinien się charakteryzować szybkim działaniem, aby zminimalizować szansę nawrotu choroby. W tym kontekście potencjalne inhibitory superenhancerów wydają się szczególnie wartościową opcją terapeutyczną.

\section{Zespoły mielodysplastyczne i nowotwory} mieloproliferacyjne Ph-ujemne (Ph-) dr hab. n. med. Joanna Góra-Tybor, prof. nadzw. Zespoły mielodysplastyczne

Nadal bardzo aktualnym tematem pozostaje wpływ mutacji somatycznych dotyczących genów biorących udział w metylacji DNA (TET2, DNMT3A, $I D H 1 / 2)$, procesach splicingu mRNA (SRFS2, SF3B1), potranslacyjnej modyfikacji histonów (ASXL1, EZH2), procesach naprawy DNA (TP53), czynników transkrypcyjnych (RUNX1, ETV6) czy moleku1 sygnałowych (NRAS, FLT3) na przebieg kliniczny MDS. Nagata i wsp (streszczenie 583) u 1809 chorych na MDS zidentyfikowali 2722 mutacji somatycznych, w tym 563 mutacji dominujących (founder) i 2159 wtórnych (subclonal). Najczęstsze mutacje dominujące, takie jak: SF3B1, TET2, DNMT3A, SRSF2, $A S X L 1$, wykluczały się wzajemnie. Autorzy zaobserwowali, że żadna $z$ mutacji nie była zawsze dominująca, ale niektóre były zawsze wtórne, na przykład FLT3, NRAS. Stwierdzono, że w przypadku pewnych mutacji znaczenie rokownicze jest inne zależnie od pozycji — dominującej w porównaniu z wtórną. Takie mutacje, jak: TP53, RUNX1, STAG2, ASXL1, wpływają niekorzystnie na OS, niezależnie od tego, czy są dominujące czy wtórne, natomiast obecność mutacji SF3B1 jest zawsze korzystnym czynnikiem rokowniczym dla OS. Bardzo ciekawą obserwacją jest wykrycie zależności między rodzajem mutacji i obrazem klinicznym choroby. Pojawianie się pewnych mutacji wiąże się $z$ mieloproliferacyjnym fenotypem choroby, a innych $-z$ nasileniem zmian dysplastycznych i progresją do bardziej zaawansowanych faz choroby. Wydaje się, że w najbliższych latach profil mutacji somatycznych będzie niezbędnym elementem skal prognostycznych dla MDS.

Palenie tytoniu jest znanym czynnikiem ryzyka zachorowania na MDS. Yazan i wsp. (streszczenie 424) badali wpływ palenia tytoniu na profil genetyczny MDS. Stwierdzili, że długoletnich palaczy charakteryzują wyższe kategorie ryzyka 
MDS według skali IPSS-R (International Prognostis Scoring System-Revised) $(\mathrm{p}=0,012)$ i wyższe ryzyko cytogenetyczne $(\mathrm{p}=0,037)$. Długoletnie, intensywne palenie tytoniu sprzyja występowaniu mutacji $E Z H 2$ i delecji chromosomu 7. Na Konferencji ASH w 2017 roku zaprezentowano również badania, które wskazują na ważną rolę rokowniczą prostych w ocenie parametrów morfologii krwi obwodowej. Itzykson i wsp. (streszczenie 158) na podstawie danych ponad 1600 pacjentów objętych rejestrem EUMDS (European LeukemiaNet Lower-Risk MDS Registry) stwierdzili, że zmniejszenie liczby PLT o co najmniej 25\% i pojawienie się zależności od transfuzji koncentratu krwinek czerwonych (kkcz) w okresie 6 miesięcy od rozpoznania MDS stanowią niezależny od IPSS-R niekorzystny czynnik rokowniczy odnoszący się do OS. Shapiro i Lazo-Langner (streszczenie 1706) oceniali czynniki ryzyka niepowodzenia terapii azacytydyną (AZA) u pacjentów $z$ MDS o ryzyku pośrednim-2 i wysokim według IPSS. Stwierdzili oni, że najsilniejszym predyktorem niepowodzenia leczenia jest nieefektywna erytropoeza po 3 cyklach terapii, natomiast najwcześniejszym wskaźnikiem progresji choroby, po początkowo dobrej odpowiedzi na AZA, jest pojawienie się neutropenii i małopłytkowości.

Podstawowym problemem chorych na MDS o niskim i pośrednim-1 ryzyku według IPSS pozostaje niedokrwistość. W tej grupie chorych poprawa parametrów czerwonokrwinkowych i uniezależnienie od przetoczeń jest głównym celem terapeutycznym. Platzbecker i wsp. (streszczenie 2982) przedstawili wyniki badania II fazy PACE-MDS (Study of ACE-536 for the Treatment of Anemia in Patients With Myelodysplastic Syndromes), w którym pacjenci z MDS niższego ryzyka i niedokrwistością byli leczeni luspaterceptem. Lek ten jest fuzyjnym białkiem ze zmodyfikowanym receptorem aktywiny IIB-immunoglobuliny G (IgG) Fc, a jego podstawowy mechanizm działania to hamowanie czynników $z$ rodziny TGF $\beta$ (transforming growth factor $\beta$ ). Wśród 88 leczonych pacjentów u 44 (50\%) stwierdzono poprawę $\mathrm{w}$ zakresie parametrów czerwonokrwinkowych, natomiast $23(38 \%)$ spośród 60 chorych zależnych od transfuzji uniezależniło się od przetoczeń kkcz. Odpowiedzi na leczenie występowały jednakowo często w grupie chorych leczonych wcześniej erytropoetyną (EPO) i nieotrzymujących tego hormonu. Na odpowiedź nie wpływało również stężenie endogennej EPO; tolerancja luspaterceptu była zadowalająca. Planuje się badanie III fazy z zastosowaniem luspaterceptu jako leku pierwszej linii u pacjentów $z$ niedokrwistością $\mathrm{w}$ przebiegu MDS niższego ryzyka.
Fenaux i wsp. (streszczenie 4256) oceniali skuteczność inhibitora telomerazy - imetelstatu $\mathrm{u}$ chorych na MDS niższego ryzyka, zależnych od przetoczeń kkcz, u których leczenie EPO było nieskuteczne. W badanej grupie $38 \%$ chorych dodatkowo było wcześniej leczonych lenalidomidem, a 25\% - decytabiną (DEC) lub AZA. Uniezależnienie od transfuzji kkcz obserwowano u $34 \%$ pacjentów, a u dalszych $63 \%$ - poprawę w zakresie parametrów układu czerwonokrwinkowego. Mediana czasu do osiągnięcia uniezależnienia od przetoczeń kkcz wynosiła 8 tygodni, a mediana czasu jej trwania 19 tygodni. Odpowiedzi u pacjentów ze stężeniem endogennej EPO nieprzekraczającym $500 \mathrm{mj} . / 1$ w porównaniu $z$ wyższym od $500 \mathrm{mj} . / 1$ nie różniły się istotnie. Lek był dość dobrze tolerowany; najczęściej obserwowano hematologiczne objawy niepożądane, w tym neutropenię 3 . lub wyższego stopnia u $66 \%$ i trombocytopenię 3 . lub wyższego u $50 \%$ pacjentów.

Liczne prezentowane badania I i II fazy dotyczyły zastosowania nowych leków w leczeniu chorych na MDS. Na szczególną uwagę zasługują połączenie AZA i sirolimusu (streszczenie 4267), połączenie AZA z ibrutynibem (streszczenie 2967), połączenie ASTX727 (doustnej DEC) i CDAi (inhibitora deaminazy cytydynowej) (streszczenie 4274), połączenie tosedostatu (inhibitora M1 i M17) $z$ aminopeptydazą (streszczenie 2966) oraz zastosowanie omacetaksyny (streszczenie 2967),

\section{Nowotwory mieloproliferacyjne $\mathrm{Ph}(-)$}

$\mathrm{Na}$ poprzedniej Konferencji ASH w 2016 roku po raz pierwszy zaprezentowano wyniki randomizowanego badania PROUD, które służyło porównaniu skuteczności hydroksykarbamidu (HU) i ropeginterferonu (Ropeg) w pierwszej linii leczenia chorych na czerwienicę prawdziwą (PV, polycythemia vera). Ropeg jest nowym preparatem interferonu (IFN), o przedłużonym działaniu, stosowanym w iniekcjach podskórnych co 2 tygodnie. Celem pierwszorzędowym badania była ocena skuteczności obu terapii pod względem częstości osiaganych całkowitych odpowiedzi hematologicznych (CHR, complete hematologic response) - badanie typu non-inferiority. Po 12 miesiącach CHR osiągnęło 43,1\% pacjentów w grupie leczonej IFN i 45,6\% w grupie przyjmującej HU, a zatem Ropeg spełnił kryterium non-inferiority względem HU. Tolerancja preparatu Ropeg była bardzo dobra, w szczególności nie obserwowano zwiększonej częstości depresji, zaburzeń endokrynologicznych ani chorób układu sercowo-naczyniowego. W grupie chorych leczonych IFN stwierdzono 
istotnie mniej powikłań hematologicznych, takich jak: niedokrwistość, małopłytkowość, leukopenia. Na konferencji ASH w 2017 roku Gisslinger i wsp. (streszczenie 320) przedstawili aktualizację wyników badania PROUD. Analizie poddano 88 pacjentów leczonych preparatem Ropeg i 73 przyjmujących HU, którzy zakończyli 24-miesięczny okres terapii. Przerwanie leczenia w 2 . ro$\mathrm{ku}$ obserwacji dotyczyło 8,4\% chorych otrzymujących Ropeg i 6,6\% w grupie leczonej HU. Po 24 miesiącach leczenia zaobserwowano wyraźną przewagę skuteczności preparatu Ropeg nad HU. W grupach chorych leczonych preparatem Ropeg oraz HU obserwowano odpowiednio 70,5\% i 49,3\% CHR ( $\mathrm{p}=0,0101)$. Dodatkowo CHR i poprawę w zakresie objawów ogólnych obserwowano u 49,5\% chorych leczonych preparatem Ropeg i $36,6 \%$ otrzymujących HU ( $p=0,1183$ ). Ponadto $\mathrm{u}$ istotnie większego odsetka chorych leczonych tym pierwszym stwierdzano redukcję zmutowanego allela JAK2 $(69,6 \%$ v. 28,6\%; $\mathrm{p}=0,0046)$. Profil toksyczności preparatu Ropeg pozostawał bardzo dobry. Hematologiczne objawy niepożądane — niedokrwistość, małopłytkowość, leukopenia - częściej występowały u pacjentów leczonych HU, natomiast podwyższenie wartości transaminaz alaninowej (AlAT, alanine aminotransferase) i asparaginowej (AspAT, aspartate aminotransferase) częściej obserwowano w grupie przyjmującej Ropeg. Objawy typowe dla IFN, tj. depresja, zaburzenia endokrynologiczne, występowały u mniej niż 5\% pacjentów w grupie otrzymującej Ropeg. Podsumowując, należy podkreślić, że po 2 latach obserwacji Ropeg wykazuje większą skuteczność w zakresie odsetka CHR i zmniejszania stężenia zmutowanego allela JAK2 w porównaniu $z$ HU. W przypadku terapii immunomodulującej, jaką jest leczenie za pomocą IFN, można się spodziewać dalszej poprawy skuteczności w kolejnych latach obserwacji. Dłuższej obserwacji wymaga również ocena częstości powikłań zakrzepowo-zatorowych, wtórnych nowotworów, transformacji do mielofibrozy (MF, myelofibrosis) i AML.

Iannotto i wsp. (streszczenie 323) zaprezentowali aktualizację wyników prospektywnego badania obserwacyjnego, w którym u 62 pacjentów $z$ pierwotną mielofibrozą (PMF, primary myelofibrosis) wdrożono terapię pegylowanym IFN $\alpha-2 \mathrm{a}$ w latach 2006-2011. U 82\% pacjentów obserwowano ograniczenie objawów ogólnych, u $83 \%$ normalizację nadpłytkowości, u $69 \%$ normalizację leukocytozy, natomiast u $46 \%$ zmniejszenie śledziony. Po okresie obserwacji wynoszącym 58 miesięcy 30 pacjentów $(48,4 \%)$ nadal żyje (mediana OS wynosi 7,4 roku), a przeżycie jest istotnie dłuższe od spodziewanego w danej kategorii DIPSS (Dynamic International Prognostic Scoring System) - 6,9 w porównaniu $z$ latami u chorych cechujących się ryzykiem pośrednim-2 i 4,58 w porównaniu z 1,5 roku u pacjentów obciążonych wysokim ryzykiem. Badanie to jest jednym $z$ wielu wskazujących na istotną rolę IFN w leczeniu chorych na PMF.

Mielofibroza jest chorobą o najcięższym przebiegu w grupie MPN, dlatego allo-HSCT ma usankcjonowaną pozycję w jej leczeniu. Jednak $z$ powodu wysokiej śmiertelności okołoprzeszczepowej allo-HSCT zarezerwowano dla zaawansowanych faz tej choroby - pacjentów $z$ prognozowaną medianą czasu przeżycia poniżej 5 lat, czyli z grup pośredniego-2 i wysokiego ryzyka według skal prognostycznych IPSS, DIPSS, DIPSS Plus. W ostatnich latach zwraca się uwagę na rolę rokowniczą zmian molekularnych i konieczność ich uwzględnienia przy kwalifikacji do allo-HSCT. Na Konferencji ASH w 2017 roku Vannucchi i wsp. (streszczenie 200) zaproponowali skalę prognostyczną MIPSS70 (Mutation-Enhanced International Prognostic Score System for Transplantation-Age Patients With Primary Myelofibrosis) dla pacjentów poniżej 70. roku życia, u których rozważa się allo-HSCT. Skala ta uwzględnia zarówno tradycyjne czynniki ryzyka, takie jak: leukocytoza ponad $25 \mathrm{G} / 1$, liczba PLT poniżej $100 \mathrm{G} / \mathrm{l}$, stężenie hemoglobiny mniejsze niż $100 \mathrm{G} / 1$, odstek blastów większy lub równy $2 \%$, wytępowanie objawów ogólnych, zwłóknienia w szpiku $>2$, jak i molekularne: nieobecność mutacji $C A L R$ typu 1, obecność mutacji epigenetycznej należącej do tak zwanej grupy wysokiego ryzyka (ASXL1, SRSF2, EZH2, IDH1/2). Dodatkowo w skali MIPSS70 plus uwzględniono obecność niekorzystnego kariotypu. Ali i wsp (streszczenie 199) przedstawili wyniki allo-HSCT dużej grupy 110 pacjentów $z$ MF hospitalizowanych w latach 2004-2017 w City of Hope Medical Centre w Kalifornii. Mediana wieku chorych wynosiła 58,5 roku (zakres 38-72 lat), a mediana czasu od diagnozy 15,2 miesiąca (zakres 1,6-332,5 miesiąca). U większości chorych $(76 \%)$ przeszczepienie wykonano w zaawansowanej fazie choroby (DIPSS pośredni-2 i wysoki). U 49 chorych allo-HSCT wykonano od $\mathrm{w}$ pełni zgodnego dawcy rodzinnego, u 32 - od w pełni zgodnego dawcy niespokrewnionego, a u 27 - od nie w pełni zgodnego dawcy niespokrewnionego. Szesnastu chorych przed allo-HSCT zostało poddanych splenektomii, 32 było leczonych ruksolitynibem. Wszyscy chorzy otrzymali kondycjonowanie FluMel (fludarabina i melfalan). Tylko u 2 pacjentów obserwowano brak wszczepu, 2-letnie 
OS wyniosło $75 \%$, a 5-letnie $65 \%$. Śmiertelność niezwiązana ze wznową choroby po 2 latach wynosiła $12 \%$, a po 5 latach $18 \%$, natomiast CIR - $17 \%$. Ostrą postać GvHD w stopniu 3.-4. obserwowano u $17 \%$ chorych, a skumulowana częstość przewlekłej postaci GvHD w 36. miesiącu wynosiła $66 \%$. U pacjentów leczonych ruksolitynibem przed allo-HSCT obserwowano wyższy odsetek ostrej postaci GvHD ( $\mathrm{p}=0,011)$, co może się wiązać z zespołem uwalniania cytokin po odstawieniu leku. Analiza jednowariancyjna wykazała, że pacjenci po allo-HSCT od dawcy niespokrewnionego żyli istotnie krócej $(\mathrm{p}=0,045)$ niż chorzy, którzy otrzymali przeszczep od dawcy rodzinnego. Splenektomia przed transplantacją wiązała się ze zwiększonym ryzykiem wznowy choroby $(\mathrm{p}=0,018)$. Podsumowując, należy podkreślić, że w przedstawianej analizie wyniki allo-HSCT są bardzo dobre, z 5-letnim OS wynoszącym 65\% i CIR równym $17 \%$. Mediana wieku chorych wynosiła 58,5 roku, a $43(39 \%)$ pacjentów miało powyżej 60 lat.

Liczne prezentowane na ostatniej Konferencji ASH wyniki badań I i II fazy dotyczyły zastosowania nowych leków w MF. Na uwagę zasługują badania z zastosowaniem: glasdegibu — inhibitora ścieżki Hedgehog (streszczenie 2580), sotaterceptu (modyfikowany receptor aktywiny IIB-IgG Fc — ligand kwaśnej fosfatazy opornej na winian [TRAP, tartrate resistant acid phosphatase] dla rodziny TGF $\beta$ ) (streszczenie 255), alisertibu — inhibitora kinaz Aurora (streszczenie 1631), połączeń ruksolitynibu $z$ lekami demetylujacymi, inhibitorami deacetylazy histonu i lekami immunomodulującymi (streszczenia 1649, 4179).

\section{Przewlekła białaczka szpikowa}

dr hab. n. med. Tomasz Sacha

Doniesienia dotyczące przewlekłej białaczki szpikowej (CML, chronic myelogenous leukemia) prezentowane podczas 59. Konferencji ASH w 2017 roku można podzielić na cztery grupy tematyczne, w tym dotyczące: 1) oporności na inhibitory kinaz tyrozynowych (TKI, tyrosine kinase inhibitors), progresji choroby oraz prób eliminacji białaczkowych komórek macierzystych; 2) badań klinicznych $z$ zastosowaniem TKI, prób ich odstawienia u chorych $z$ głęboką odpowiedzią molekularną głęboką odpowiedź molekularną (DMR, deep molecular response) oraz analizy poświęcone biomarkerom utrzymania długotrwałego przeżycia wolnego od ponownego wdrożenia leczenia (TFS, treatment-free survival); 3) raportów $\mathrm{z}$ rejestrów chorych na CML; 4) zastosowania $w$ praktyce nowych technologii diagnostycznych.
Oporność na TKI, progresja choroby oraz próby eliminacji białaczkowych komórek macierzystych

Znaczenie występowania dodatkowych klonalnych zaburzeń cytogenetycznych w komórkach bez chromosomu Filadelfia (CCA/Ph-, clonal cytogenetic abnormalities Philadelphia-negative) nie jest do końca poznane. Autorzy dotychczasowych doniesień sugerowali, że ich pojawienie się ma charakter przemijający i nie pogarsza rokowania w przebiegu leczenia CML. Ghayas i wsp. (streszczenie 47) postanowili zastosować metodę celowanego głębokiego sekwencjonowania (TDS, targeted deep sequencing) i przebadać komórki pobrane od chorych $\mathrm{z}$ wykrywanymi $\mathrm{CCA} / \mathrm{Ph}(-)$, którzy stanowili około 10\% leczonej na CML populacji. Wykrycie dodatkowej aberracji cytogenetycznej w przynajmniej 2 spośród 20 ocenianych metafaz $\mathrm{Ph}(-)$ lub wykrycie tej aberracji w przynajmniej dwóch kolejnych badaniach cytogenetycznych spełniało definicję CCA/Ph(-). U tych chorych wykonano TDS, używając panelu 295 genów, które ulegają mutacjom $\mathrm{w}$ sposób powtarzalny w przebiegu w nowotworowych schorzeń układu krwiotwórczego. Dodatkowe zaburzenia cytogenetyczne wykryto u 58 chorych, w tym utratę chromosomu Y u 25 (43\%), a trisomię 8 u 7 (12\%) pacjentów. $\mathrm{U} 62 \%$ chorych CCA/Ph(-) występowały przejściowo. Metodą TDS u 10 chorych wykryto 46 mutacji wiodących występujących w 18 genach. Odsetek wykrytych mutacji był większy niż spodziewany u chorych na CML w fazie przewlekłej (CP, chronic phase). Do najczęściej wykrywanych mutacji należały: $A S X L-1$ (wykryta u 10/10 pacjentów) i PTPN11 (wykryta u 7/10 pacjentów), u jednej osoby wykryto DNMT3A (R635Q), ABL (Y253) i $A S X L-1$. U chorych $z$ CCA-Ph(-), z wyłączeniem pacjentów $\mathrm{z}$ utratą chromosomu $\mathrm{Y}$, stwierdzono krótsze 5-letnie przeżycia wolne od niepowodzenia terapii (FFS, failure-free survival) (52\% v. 70\%), EFS $(68 \% v .86 \%)$, przeżycia wolne od transformacji w kryzę blastyczną (BP, blastic phase) $(76 \%$ v. $94 \%$ ) oraz OS (79\% v. 94\%). Niekorzystne znaczenie rokownicze wykrywanych mutacji znikało, jeśli w 3. miesiącu leczenia TKI uzyskano redukcję ilości transkryptu $B C R / A B L 1$ do mniej niż $10 \%$ (EMR, early molecular response).

W trakcie badań nad opornością komórek CML niezależną od genu $B C R / A B L 1$ zauważono, że komórki oporne na TKI wymagają do przeżycia sprawnego mechanizmu transportu jądrowo-cytoplazmatycznego (NCE, nucleocytoplasmic export) i są wrażliwe na utratę białka RAN regulującego NCE, a także na selektywne inhibitory tego transportu (KPT-330; Selinexor). Than i wsp. (streszczenie 42) wysunęli 
hipotezę, że mechanizm NCE może być zaangażowany w zjawisko uśpienia macierzystych komórek CML, które nie są wrażliwe na mechanizmy blokowania genu $B C R / A B L 1$. Jednoczesne zastosowanie $\mathrm{w}$ badaniach in vitro imatynibu i KPT-300 $\mathrm{w}$ znacznie większym stopniu hamowało formowanie jednostek tworzących kolonie granulocytów i makrofagów (CFU-GM, colony-forming units - granulocyte macrophage) z komórek macierzystych CML (LSC) i komórek progenitorowych (LPC, leukemic progenitor cells) pobranych chorych $z$ nowo rozpoznana CML oraz komórek pobranych $z$ krwi pępowinowej i bardziej zwiększało ich apoptozę niż stosowanie każdego $z$ tych leków osobno. Różnice w każdym $z$ tych przypadków były istotne statystycznie.

\section{Badania kliniczne dotyczące TKI,}

prób ich odstawienia u chorych z DMR

oraz analizy poświęcone biomarkerom utrzymania długotrwałego TFS

Cortes i wsp. (streszczenie 1590) przedstawili wyniki 7-letniej (jak dotąd najdłuższej) obserwacji dotyczącej bezpieczeństwa leczenia TKI — bosutynibem poświęconej wpływowi tego leku na układ sercowo-naczyniowy. Badanie obejmowało 570 chorych, spośród których 284 otrzymywało bosutynib w drugiej linii leczenia, 119 było leczonych w trzeciej linii (CP) i 167 chorych w BP lub chorych na ostrą białaczkę limfoblastyczną $z$ chromosomem Filadelfia (ALL-Ph+, acute lymphoblastic leukemia Philadelphia-positive). W wywiadzie epizod sercowy odnotowano u $22 \%$, a naczyniowy lub związany z nadciśnieniem tętniczym - u 33\% chorych. Działania niepożądane wszystkich stopni, w stopniu ciężkim oraz wiodące do odstawienia bosutynibu w trzech kategoriach: epizod sercowy, epizod naczyniowy, epizod związany $z$ nadciśnieniem tętniczym, odnotowano odpowiednio u $14 \%, 6 \%$ i $2 \%$ chorych, u $9 \%, 7 \%$ i $2 \%$ chorych oraz u $9 \%$, $1 \%$ i $0 \%$ chorych. Autorzy konkludują, że odsetek zdarzeń niepożądanych był relatywnie niski i nie zależał ani od linii leczenia, ani od fazy choroby, a pojawiające się objawy toksyczności w obrębie układu sercowo-naczyniowego bardzo rzadko prowadziły do zaprzestania leczenia. Opublikowane przez Hochhausa i wsp. (streszczenie 1618) wyniki leczenia bosutynibem w pierwszej linii leczenia (badanie BFORE [Bosutinib Could Be a "Welcome" New Treatment Option for Chronic-Phase CML]) wskazują, że chorzy otrzymujący bosutynib w dawce $400 \mathrm{mg} /$ dobę znamiennie częściej niż pacjenci leczeni imatynibem w dawce $400 \mathrm{mg} /$ dobę uzyskują wczesną odpowiedź molekularną (80,6\% v. 60,5\%; $\mathrm{p}<0,0001$ ), a szansa na osiągnięcie większej odpowiedzi molekularnej (MMR, major molecular response) w 12. miesiącu leczenia jest znacznie większa u chorych $z$ redukcją ilości transkryptu $B C R / A B L 1$ do mniej niż $10 \%$ w 3 . miesiącu leczenia za pomocą TKI. Do najczęściej występujących działań niepożądanych w stopniu 3. lub 4. należały: biegunka u 8\% chorych, zwiększenie stężeń AlAT i AspAT odpowiednio u $21 \%$ i $10 \%$ chorych oraz małopłytkowość u $14 \%$ chorych. Wystąpienie powyższych działań niepożądanych bardzo rzadko było przyczyną odstawienia bosulifu (odpowiednio u $0,7 \%, 4 \%, 3 \%$ i $1 \%$ chorych). Raport Hochhausa i wsp. (streszczenie 1617) dotyczący 270 chorych opornych na uprzednio stosowane TKI $(60 \%$ otrzymało $\geq 3$ linie terapii) leczonych ponatynibem w ramach badania PACE (Efficacy and Safety of Ponatinib in Chronic Phase-Chronic Myeloid Leukemia (CP-CML) According to the Extent of Treatment with Prior Tyrosine Kinase Inhibitors) (obserwacja 5-letnia) wskazuje, że szanse dobrej odpowiedzi na leczenie są tym większe im mniej linii leczenia TKI zastosowano wcześniej. Odsetki osiągniętej całkowitej odpowiedzi cytogenetycznej (CCR, complete cytogenetic response), 5-letniego PFS i OS u chorych leczonych ponatynibem po leczeniu jednym, dwoma, trzema i czterema kolejnymi TKI wynoszą, odpowiednio, 79\%, 65\%, 46\% i 33\% w przypadku CCR, $62 \%, 68 \%$, 45\% i nieosiągnięta (NA, non-achieved) w przypadku PFS oraz 89\%, $78 \%, 73 \%$ i NA w przypadku OS. W trakcie tego badania epizody okluzji naczyń tętniczych pojawiły się u $31 \%$ chorych (wszystkie stopnie), przy czym u 26\% oceniono je jako poważne. Występowały one najczęściej u chorych leczonych ponatynibem w dawce $45 \mathrm{mg} /$ dobę obciążonych co najmniej dwoma czynnikami ryzyka choroby układu sercowo-naczyniowego. Częstość występowania powikłań $\mathrm{w}$ tym układzie obniżała się $z$ upływem trwania badania i wraz ze zmniejszaniem stosowanej dawki leku (streszczenie 2896). Retrospektywna analiza skuteczności leczenia trzeciej linii TKI u 185 chorych w $\mathrm{CP}$ opornych na leczenie pierwszej i drugiej linii przedstawiona przez Khan i wsp. (streszczenie 2882) sugeruje, $\dot{z}$ e ponatynib i bosutynib są istotnie bardziej skuteczne niż imatynib, a najdłuższe OS obserwuje się u chorych leczonych ponatynibem (wynosi 80\% po 84 miesiącach). Doniesienie Naqvi i wsp. (streszczenie 1611) dotyczące prospektywnej analizy 56 chorych na CML w CP leczonych w MD Anderson Cancer Center małą dawką dazatynibu $(50 \mathrm{mg} / \mathrm{d}$ ) po maksymalnie miesięcznym okresie leczenia TKI jest równie skuteczne, jak terapia za pomocą dawki $100 \mathrm{mg} /$ dobę. Wczesną odpowiedź molekularną uzyskało 93\% chorych, a CCR, MMR 
i MR4 (molecular response $4 \log$ ) w 12 . miesiącu leczenia - wszyscy chorzy. W tym okresie nie odnotowano żadnego epizodu wysięku opłucnowego, nikt nie wymagał modyfikacji dawki, a do czasowych przerw w leczeniu doszło u 9 chorych ( $\mathrm{u} 2 \mathrm{z}$ powodu krwawienia $\mathrm{z}$ przewodu pokarmowego, $\mathrm{u} 3 \mathrm{z}$ powodu małopłytkowości, $\mathrm{u} 2 \mathrm{z}$ powodu podwyższenia stężenia AspAT lub AlAT i u 2 z powodu niewydolności nerek). Podobne doświadczenia ze stosowaniem nilotynibu w zmniejszonej dawce stosowanej raz/dobę przedstawili Rea i wsp. (streszczenie 318). Lek w jednorazowej dawce od $300 \mathrm{mg} /$ /dobę do $450 \mathrm{mg} /$ dobę stosowano u 82 chorych, w tym u 24, u których nilotynib podawano w drugiej linii leczenia (u $8 \mathrm{z}$ powodu oporności na leczenie 1. linii). Dawkę leku zmniejszano u chorych, którzy osiągnęli przynajmniej MMR. Po 12 miesiącach obserwacji spośród 71 chorych poddanych analizie utratę MMR po 4 miesiącach terapii stwierdzono u 2 chorych (wzrost w badaniu ilościowym reakcji łańcuchowej polimerazy [RQ-PCR, real-time quantitative polymerase chain reaction] do $0,13 \%$ i $0,11 \%$ ), u których mimo braku modyfikacji dawkowania w kolejnych badaniach ilościowych metodą PCR doszło do odzyskania MMR i utrzymania jej do końca analizowanego okresu 12 miesięcy. $\mathrm{W}$ trakcie leczenia jednorazową zmniejszoną dawką obserwowano stopniowe pogłębianie się odpowiedzi molekularnej. Na podstawie między innymi tych doświadczeń zaproponowano przyszły model leczenia chorych na CML polegający na uzyskaniu optymalnej odpowiedzi pełną dawką stosowanego TKI. Po tym okresie miałby następować okres konsolidacji tej odpowiedzi za pomocą TKI podawanego $\mathrm{w}$ zmniejszonej dawce i u chorych osiągających DMR — MR4 lub MR4,5 — rozważenie odstawienia leczenia. Wyniki badań ENESTfreedom (Nilotinib Treatment-free Remission Study in CML [Chronic Myeloid Leukemia] Patients) i ENESTop (Treatment-free Remission After Achieving Sustained MR4.5 on Nilotinib) prezentowane przez Saglio i wsp. (streszczenie 1598) wskazują na możliwość uzyskania długotrwałej remisji wolnej od leczenia (TFR, treatment-free remission), której odsetek w 48. tygodniu obserwacji wynosi w tych badaniach odpowiednio $51,6 \%$ i $57,9 \%$. Zasadnicza różnica $\mathrm{w}$ charakterystyce grup pacjentów leczonych według powyższych protokołów dotyczyła długości okresów leczenia TKI i leczenia nilotynibem (większe w ENESTop). Podobne rezultaty uzyskane w toku tych badań sugerują, że zasadnicze znaczenie dla uzyskania i utrzymania TFR ma długość trwania DMR osiagniętej przed odstawieniem TKI. Dwa biomarkery istotne dla uzyskania i długotrwałego utrzymania TFR to, według badania EURO-SKI (European Stop Tyrosine Kinase Inhibitor) (streszczenie 313) długość okresu leczenia TKI (ryzyko utraty MMR u chorych leczonych TKI > 5,8 roku wynosi 34\%) oraz długość trwania DMR (MR4 w EURO-SKI); ryzyko utraty MMR u chorych z MR4 ponad 3,1 roku wynosi 38\%. Spośród nich ten ostatni ma większe znaczenie. Analizy statystyczne sugerują, że każdy dodatkowy rok terapii TKI zwiększa szansę na długotrwałą TFR o $0,86 \%$, natomiast każdy dodatkowy rok pozostawania w MR4 - o 3\%.

Pfirrmann i wsp. (streszczenie 1601) przedstawili wynik analizy, w której porównano szanse na TFR u chorych leczonych imatynibem i nilotynibem. Do analizy porównawczej wyodrębniono dwie podobne grupy chorych $z$ badania EURO-SKI oraz badania ENSTfreedom. Byli to pacjenci $z$ badania EURO-SKI, którzy nigdy nie otrzymywali IFN $\alpha$, $\mathrm{w}$ momencie odstawienia imatynibu uzyskali odpowiedź MR4,5 i dobrano ich pod względem czasu leczenia TKI, wieku i płci z chorym leczonymi nilotynibem według protokołu ENESTfreedom. Prawdopodobieństwo przeżycia wolnego od nawrotu (RFS, relapse-free survival) molekularnego w 12. miesiącu po odstawieniu TKI było istotnie większe u chorych leczonych nilotynibem $(51 \% ; 95 \% \mathrm{CI}$ 39-62\%) niz imatynibem (41\%; 95\% CI 30-53\%). Shah i wsp. (streszczenie 314) przedstawili wyniki badania DASFREE (Open-Label Study Evaluating Dasatinib Therapy Discontinuation in Patients With Chronic Phase Chronic Myeloid Leukemia With Stable Complete Molecular Response), w którym zakładano odstawienie dazatynibu u chorych, którzy w toku przynajmniej 2-letniego leczenia osiągnęli odpowiedź MR4,5. Protokół zezwalał na odstawienie leku także u chorych otrzymujących dazatynib w drugiej linii leczenia $z$ powodu oporności na terapię pierwszej linii (stanowili oni $53 \%$ analizowanych chorych). Przeżycie wolne od nawrotu molekularnego w 12 . miesiącu od odstawienia wyniosło $49 \%$, a w grupie chorych opornych na leczenie pierwszej linii $-40 \%$.

\section{Raporty z rejestrów chorych na CML}

Występowanie wtórnych nowotworów u chorych na CML leczonych TKI budzi kontrowersje od wielu lat. Raport $z$ pojedynczego rejestru amerykańskiego SEER (Surveillance, Epidemiology and End Results) obejmował 13276 chorych z nowo rozpoznaną CML w latach 2001-2014 (streszczenie 1609). $Z$ analizowanej grupy wykluczono pacjentów $z$ chorobą nowotworową $\mathrm{w}$ wywiadzie lub rozpoznaną w roku diagnozy CML, a także chorych, 
u których rozwinęła się wtórna białaczka jako drugi nowotwór. Standaryzowany współczynnik występowania (SIR, standard incidence ratio) kalkulowano dla dobranej wiekowo ogólnej populacji 2000 osób. Wtórne nowotwory wykryto u 597 (4\%) chorych. Najczęściej dotyczyły one męskiego układu płciowego (130 chorych, $22 \%$ ), układu pokarmowego (121 chorych, 21\%) i układu oddechowego (91 chorych, 15\%). Autorzy podsumowują, że częstość występowania wtórnych nowotworów u chorych na CML jest tylko nieznacznie większa niż w ogólnej populacji. Drugi raport sporządzono na podstawie analizy 18 rejestrów SEER obejmujących łącznie 26810 chorych na CML wykrytej jako pierwszy nowotwór rozpoznany między styczniem 1973 roku i grudniem 2013 roku. Odsetek nowotworów wykrywanych w stosunku do spodziewanych był nieznacznie wyższy, zarówno w latach 1973-1985 oraz 1986-2000, jak i 2001-2013. W erze stosowania TKI (po 2000 r.) nie obserwowano istotnego wzrostu w tym zakresie w porównaniu $z$ latami poprzednimi. Rodzaj występujących nowotworów różni się natomiast zależnie od wieku. W grupie wiekowej 20-39 lat dominują nowotowory szyjki macicy i nosogardła, u osób w między 40. a 59. rokiem życia - czerniak i nowotwory tarczycy, natomiast u osób powyżej 60 . roku życia - nowotwory płuc, oskrzeli i chłoniaki nie-Hodgkina. Autorzy wskazują, że pojawianie się wtórnych nowotworów może być związane $z$ wydłużeniem przeżycia w przebiegu leczenia CML i zrównania długości przeżycia chorych z przeżyciem zdrowej populacji.

Raport z rejestru PALG (Polish Adult Leukemia Group) obejmujący 340 chorych leczonych imatynibem (streszczenie 2887) sugeruje, $\dot{z}$ e choroby wspólistniejące i stosowanie dodatkowych leków nie zmniejszają szans na uzyskanie wczesnej odpowiedzi molekularnej. Pacjenci z przynajmniej dwoma schorzeniami towarzyszącymi wydają się częściej osiągać założone cele terapii. Autorzy sugerują, że interakcje lekowe zwiększające stężenie imatynibu oraz większy stopień stosowania się do zaleceń lekarskich w tej grupie pacjentów mogą przynajmniej częściowo wyjaśniać to zjawisko.

\section{Zastosowania w praktyce \\ nowych technologii diagnostycznych}

Sekwencjonowanie nowej generacji (NGS, next-generation sequencing) znajduje wiele zastosowań w diagnostyce zaburzeń molekularnych w MPN. Wybrany przykład dotyczy badania tą technologią przeprowadzonego u 48 chorych na CML, którzy po 12 miesiącach leczenia TKI nie uzyskali
MMR. Z badania wykluczono chorych $z$ dodatkowymi zaburzeniami cytogenetycznymi wykrytymi w chwili diagnozy. Testy przeprowadzono, używając panelu diagnostycznego dla 48 genów $z$ regulatorami epigenetycznymi włącznie: $A S X L 1, A S X L 2$, BCOR, DNMT3A, EZH2, IDH1, IDH2, TET2. Mutacje wykryto w 27\% próbek — w jednej próbce wykryto dwie mutacje. Nie stwierdzono korelacji występowania mutacji $z$ typem transkryptu, wiekiem, płcią, stężeniem hemoglobiny, liczbą krwinek białych i odsetkiem komórek $\mathrm{Ph}(+)$ w badaniu fluorescencyjnej hybrydyzacji in situ (FISH, fluorescent in situ hybridization). W 86\% przypadków mutacje wykryto w genach modyfikujących chromatynę lub w genach odpowiedzialnych za metylację DNA. Najczęściej wykrywaną mutacją była $A S X L 1$ (stanowiła $58 \%$ wykrytych mutacji). Zaobserwowano, że odsetek mutacji $A S X L 1$ korelował z iloscią transkryptu $B C R / A B L 1$, co może świadczyć o tym, że mutacja wystąpiła w tym samym klonie komórek CML. Powyższej korelacji nie odnotowano, analizując odsetek mutacji $C A L R$, co sugeruje, że gen $B C R / A B L 1$ pojawił się w już zmutowanym klonie komórek. Zaobserwowano, że mutację $A S X L 1$ wykryto w chwili diagnozy u 8 spośród 48 chorych (17\%), którzy nie uzyskali MMR po 12 miesiącach leczenia TKI. Autorzy sugerują, że występowanie mutacji, takich jak $A S X L 1$, w chwili diagnozy może się wiązać $z$ mniejszą szansą na optymalną odpowiedź na leczenie TKI.

W podsumowaniu należy podkreślić, że wciąż są poszukiwane i wyjaśniane mechanizmy oporności na TKI i zjawiska uśpienia LSC. Jednym z nich, wspólnym dla obu powyższych, jest transport jądrowo-cytoplazmatyczny, którego zablokowanie specyficznym inhibitorem dodanym do imatynibu wiąże się ze znacznym ograniczeniem tworzenia kolonii komórek krwiotwórczych i znacznym nasileniem apoptozy. Mechanizm ten może stanowić nowy cel leczenia eliminującego LSC pozostające dotąd $\mathrm{w}$ uśpieniu. Badania nad zastosowaniem dobrze znanych już TKI przynoszą koncepcję początkowego ich stosowania w pełnych dawkach, a po osiągnięciu optymalnego wyniku tej fazy leczenia - konsolidacji uzyskanej odpowiedzi zmniejszonymi, minimalnie toksycznymi dawkami, $z$ następową próbą ich odstawienia u chorych osiągających głęboką i trwałą odpowiedź molekularną. $Z$ dwóch uznanych już biomarkerów istotnych dla uzyskania długotrwałego TFR po odstawieniu TKI, czyli długości leczenia za pomocą TKI i okresu utrzymywania się DMR, ten drugi wydaje się odgrywać istotniejszą rolę. Wyniki analiz rejestrów gromadzących dane na temat występowania 
nowotworów wskazują, że odsetek pojawiania się wtórnych do CML nowotworów jest nieznacznie większy niż w dobranej pod względem parametrów ogólnej populacji. Taka tendencja istnieje od wielu lat $\mathrm{i}$ była obserwowana także przed erą stosowania TKI w leczeniu CML i wiąże się raczej $z$ faktem wydłużania i zrównania przeżycia w tej chorobie $z$ ogólną populacją niż z metodą stosowanego leczenia farmakologicznego. Zastosowanie NGS pozwala między innymi na bardziej precyzyjną identyfikację chorych na CML, u których można się spodziewać problemów z uzyskaniem optymalnej odpowiedzi na leczenie za pomocą TKI.

\section{Ostra białaczka szpikowa}

dr hab. n. med. Agnieszka Wierzbowska, prof. nadzw.

Główne doniesienia dotyczące AML prezentowane na 59. Konferencji ASH obejmowały zagadnienia związane $z$ zastosowaniem nowych leków, terapii celowanej i immunoterapii oraz znaczenia nowoczesnych metod molekularnych w monitorowaniu MRD.

Ostra białaczka promielocytowa (APL, acute promyelocytic leukemia) jest szczególną postacią AML o odmiennej biologii, obrazie klinicznym i z dużą szansą na wyleczenie dzięki zastosowaniu terapii celowanych kwasem all-transretynowego (ATRA, all-trans retinoic acid) i trójtlenku arsenu (ATO, arsenic trioxide). Leczenie skojarzone ATO w połączeniu z ATRA (ATO + ATRA) jest obecnie standardową opcją leczenia u chorych $z$ nowo rozpoznaną APL $z$ grup niskiego- i pośredniego ryzyka umożliwiającą wyleczenie ponad 95\% chorych. W ostatnich latach podejmowano próby wykorzystania innych związków arsenu i nowych pochodnych retinoidów w leczeniu APL; RIF (Realgar-Indigo naturalis formula) jest doustnym lekiem stosowanym w chińskiej medycynie ludowej zawierającym czterosiarczek arsenu. W pilotażowym badaniu wykazano wysoką skuteczność RIF z ATRA (RIF + ATRA) w leczeniu nowo rozpoznanej APL.

Na ostatniej Konferencji ASH przedstawiono wyniki randomizowanego badania typu non-inferiority, w którym porównano standardowe leczenie ATO + ATRA ze skojarzoną terapią doustną RIF + ATRA u chorych $z$ nowo rozpoznaną APL $z$ grup niskiego- i pośredniego ryzyka (streszczenie 641 ). W latach 2014-2017 randomizacji w stosunku 2:1 do leczenia indukującego RIF (60 mg/kg mc.) + + ATRA $\left(25 \mathrm{mg} / \mathrm{m}^{2}\right)$ lub ATO $(0,16 \mathrm{mg} / \mathrm{kg} \mathrm{mc})+$. + ATRA $\left(25 \mathrm{mg} / \mathrm{m}^{2}\right)$, stosowanych w sposób ciągły do czasu uzyskania remisji hematologicznej, poddano 109 chorych. W leczeniu poremisyjnym stosowano 4-tygodniowe cykle RIF lub ATO co 8 tygodni w skojarzeniu $z$ ATRA, podawanym w 2-tygodniowych kursach co 4 tygodnie przez 7 kolejnych miesięcy.

W badaniu odsetek $\mathrm{CR}$ w obu grupach byl porównywalny ( $100 \%$ v. $94,4 \%$ odpowiednio dla RIF + ATRA oraz ATO + ATRA; $p=0,12)$. Przy medianie czasu obserwacji wynoszącej 32 miesiące 2-letnie EFS wynosiło 97,1\% w grupie leczonej RIF + ATRA w porównaniu $z$ 94,4\% w grupie leczonej ATO + ATRA i nie różniło się istotnie. Podobnie odsetki nawrotów (RR, relapse rate) i OS były porównywalne w obu grupach. Autorzy konkludują, że skuteczność i tolerancja leczenia RIF + ATRA nie różni się od standardowej terapii ATO + ATRA $\mathrm{u}$ chorych $\mathrm{z}$ APL niskiego i pośredniego ryzyka. Ze względu na doustną formułę leczenia terapia RIF + ATRA może być stosowana w warunkach ambulatoryjnych.

Tamibaroten jest nowym, syntetycznym retinoidem, który charakteryzuje się 10-krotnie większą niż ATRA indukcją różnicowania linii NB-4 in vitro, większą stabilnością chemiczną i niższym powinowactwem do wewnątrzkomórkowych białek wiążących kwas retinowy (RA, retinoic acid). W badaniu grupy japońskiej JALSG (Japan Adult Leukemia Study Group) APL204 oceniono skuteczność i tolerancję tamibarotenu w leczeniu podtrzymującym $u$ chorych $z$ nowo rozpoznaną APL (streszczenie 642).

Badaniem objęto 347 chorych $z$ APL w wieku od 15 do 70 lat, w dobrym stanie ogólnym (0-3 wg ECOG [Eastern Cooperative Oncology Group]). Wszystkich pacjentów poddano leczeniu indukującemu i konsolidującemu dostosowanemu do grupy ryzyka ocenianego na podstawie leukocytozy i liczby blastów w krwi obwodowej. Chorzy, którzy uzyskali remisję molekularną po zakończeniu leczenia konsolidującego, zostali objęci randomizacją do leczenia podtrzymującego tamibarotenem w dawce $6 \mathrm{mg} / \mathrm{m}^{2} /$ dobę przez 14 dni lub ATRA w dawce $45 \mathrm{mg} / \mathrm{m}^{2} /$ dobę przez 14 dni. Dwutygodniowe kursy leczenia podtrzymującego powtarzano co 3 miesiące przez 2 kolejne lata. Pierwotnym punktem końcowym było RFS.

Trzystu dziewiętnastu chorych (93\%) uzyskało CR. Po zakończeniu konsolidacji 269 chorych poddano randomizacji do leczenia podtrzymującego ATRA ( $\mathrm{n}=135)$ lub tamibarotenem $(\mathrm{n}=134)$. Przy medianie czasu obserwacji wynoszącej 7 lat 7-letnie RFS w grupie leczonej ATRA wynosiło $84 \%$, a w grupie leczonej tamibarotenem - 93\% $(\mathrm{p}=0,031)$. Różnica na korzyść podtrzymywania 
z zastosowaniem tamibarotenu była bardziej istotna, gdy analizę ograniczono do grupy chorych wysokiego ryzyka (leukocytoza $\geq 10000 / \mu$ l); 7-letnie RFS w grupach leczonej ATRA oraz leczonej tamibarotenem wynosiło, odpowiednio, $62 \%$ i $89 \%$ $(\mathrm{p}=0,034)$. Obie terapie podtrzymujące były dobrze tolerowane. Nie obserwowano istotnych różnic w zakresie częstości występowania wtórnych nowotworów (w tym hematologicznych) czy późnych powikłań kardiologicznych. Wyniki randomizowanego badania wskazują, że tamibaroten jest skuteczną opcją leczenia podtrzymującego i obniża ryzyko nawrotów w porównaniu z ATRA u chorych na APL.

Postęp w poznaniu molekularnych mechanizmów leżących u podstaw AML zaowocował syntezą nowych leków, o celowanych mechanizmach działania, których aktywność kliniczna była przedmiotem intensywnych badań. Przełomem było zarejestrowanie w 2017 roku czterech nowych leków (midostauryna, enasidenib, CPX-351 oraz gemtuzumab ozogamycyny) do leczenia chorych na AML. Wiele leków pozostaje w trakcie badań klinicznych. Do nowych obiecujących leków należy selektywny inhibitor BCL2 - wenetoklaks. Wyniki badań wskazują, że częstą przyczyną oporności na chemioterapię $\mathrm{u}$ chorych na AML jest nadmierna ekspresja antyapoptotycznego białka BCL2 w komórkach białaczkowych. Wei i wsp. (streszczenie 890) przedstawili odległe wyniki badania fazy 1b/2, w którym oceniono skuteczność i tolerancję leczenia wenetoklaksem $\mathrm{w}$ połączeniu $\mathrm{z}$ małymi dawkami arabinozydu cytozyny (LD-Ara-C, low-dose arabinoside cytosine) u osób powyżej 65. roku życia chorych na AML, którzy nie kwalifikowali się do intensywnej chemioterapii. W pierwszym cyklu leczenie wenetoklaksem rozpoczynano od dawki $50 \mathrm{mg}$ doustnie (p.o., per os), a następnie w ciągu 5 kolejnych dni stopniowo zwiększano dawkę do $800 \mathrm{mg}$ (10 chorych) lub $600 \mathrm{mg}$ p.o. (61 chorych), której stosowanie kontynuowano przez dalszy okres leczenia; LD-Ara-C podawano podskórnie (s.c., subcutaneous) w dawce $20 \mathrm{mg} / \mathrm{m}^{2} \mathrm{w}$ dniach 1.-10. co 28 dni. Do badania włączono 71 chorych w wieku od 66 do 87 lat (mediana 74 lata). Czterdzieści siedem procent chorych miało białaczkę wtórną do innych chorób układu krwiotwórczego. W grupie 61 chorych otrzymujących rekomendowaną do II fazy dawkę wenetoklaksu $600 \mathrm{mg}$ mediana czasu leczenia wynosiła 6 miesięcy (zakres od $<1$ do 21 miesięcy). Trzydziestu ośmiu (62\%) chorych uzyskało CR lub CR z niepełną regeneracją hematopoezy (CRi, CR incomplete). Mediana czasu CR/ /CRi wynosiła 14,9 miesięcy. Mediana OS w całej grupie chorych i w grupie respondentów wynosiła odpowiednio 11,4 i 18,4 miesiąca, a prawdopodobieństwo przeżycia pierwszego roku odpowiednio $46 \%$ i $70,4 \%$. Najwyższy odsetek odpowiedzi obserwowano u chorych $\mathrm{z}$ mutacją NPM1 $(100 \%$ CR/CRi) oraz z mutacją DNMT3A, FLT3-ITD i $S R S F 2(\geq 75 \% \mathrm{CR} / \mathrm{CRi})$, a najniższy - u chorych z mutacją TP53 (44\% CR/CRi). Do najczęstszych zdarzeń niepożądanych w stopniu 3.-4. należały cytopenie, gorączka neutropeniczna, nadciśnienie tętnicze, hipofosfatemia, spadek apetytu i wzrost stężenia bilirubiny. Śmiertelność w pierwszych 30 dniach była niska i wynosiła $3 \%$. Wstępne wyniki skojarzonego leczenia LD-Ara-C i wenetoklaksem są bardzo obiecujące, ale wymagają potwierdzenia w randomizowanym badaniu III fazy.

W sesji plakatowej przedstawiono aktualizację wyników badania, w którym oceniono skuteczność i tolerancję skojarzonej terapii wenetoklaksem i lekami hipometylującymi, AZA lub DEC, u chorych w 65. roku życia i starszych $z$ dotychczas nieleczoną AML, którzy nie kwalifikują się do intensywnej chemioterapii (streszczenie 2628). Wenetoklaks stosowano w dawkach 400, 800 lub $1200 \mathrm{mg} /$ dobę w skojarzeniu $\mathrm{z}$ DEC w dawce $20 \mathrm{mg} /$ $/ \mathrm{m}^{2}$ i.v. w dniach 1.-5. lub AZA w dawce $75 \mathrm{mg} /$ $/ \mathrm{m}^{2}$ i.v. lub s.c. w dniach 1.-7. co 28 dni. Analizą objęto 145 chorych w wieku 65-86 lat (mediana 74 lata). Sześćdziesięciu chorych otrzymało wenetoklaks w dawce $400 \mathrm{mg}$ ( $29 \mathrm{z}$ AZA, 31 z DEC), 74 chorych - ten sam lek w dawce $800 \mathrm{mg}$ (37 z AZA i 37 z DEC), a jedynie 11 chorych - dawkę wenetoklaksu równą $1200 \mathrm{mg}$ (5 z AZA, 6 z DEC). Blisko połowa chorych (49\%) należała do grupy niekorzystnego ryzyka cytogenetycznego. Do najczęstszych zdarzeń niepożądanych związanych $z$ wenetoklaksem, obserwowanych u co najmniej $20 \%$ leczonych chorych, należały nudności (43\%), małopłytkowość (38\%), neutropenia (34\%) i leukopenia (26\%). Pięciu chorych zmarło w pierwszych 30 dniach leczenia, w tym $3 \mathrm{z}$ powodu ciężkich powikłań infekcyjnych. Ogólny odsetek odpowiedzi wynosił $83 \%$, w tym $66 \%$ CR + CRi. Wysoki odsetek remisji obserwowano również w podgrupach chorych o niekorzystnym rokowaniu, w tym u chorych $z$ wtórną AML (sAML, secondary AML) $(65 \% \mathrm{CR}+\mathrm{CRi})$ oraz $\mathrm{w}$ grupie o niekorzystnym ryzyku cytogenetycznym (57\% CR + CRi). Przy medianie czasu obserwacji wynoszącej 7 miesięcy mediana OS wynosiła 17,5 miesiąca. Autorzy konkludują, że połączenie wenetoklaksu $\mathrm{z}$ lekami hipometylującymi charakteryzuje się wysoką skutecznością i dobrym profilem bezpieczeństwa.

Mutacje genu IDH1 i IDH2 stwierdza się u około $20 \%$ chorych na AML. Wyniki badań wska- 
zują, że mutacje IDH1/IDH2 prowadzą do zwiększonej produkcji onkometabolitu (2HG, 2-hydroksyglutaranu), który hamuje demetylazę histonową i metylotransferazę TET, w wyniku czego dochodzi do zwiększonej metylacji DNA. Zwiększona metylacja DNA hamuje ekspresję nowotworowych genów supresorowych i zaburza różnicowanie komórek. Dlatego jedną z opcji leczenia chorych z mutacjami IDH1/IDH2 jest stosowanie inhibitorów zmutowanych form tych białek, które obniżają stężenie $2 \mathrm{HG}$ w komórce. Na konferencji ASH w 2017 roku przedstawiono wiele badań służących ocenie skuteczności iwosidenibu (inhibitora IDH1) oraz enasidenibu (inhibitora $I D H 2$ ) u chorych na AML i z mutacją IDH1/IDH2 (streszczenie 726). W badaniu 1 fazy oceniono tolerancję i bezpieczeństwo skojarzenia iwosidenibu lub enasidenibu ze standardową chemioterapią u chorych $z$ mutacją odpowiednio IDH1 i IDH2. W leczeniu indukującym stosowano chemioterapię według protokołu $3+7$ (daunorubicyna [DNR] $60 \mathrm{mg} / \mathrm{m}^{2} /$ dobę lub IDA 12 $\mathrm{mg} / \mathrm{m}^{2} /$ dobę przez $3 \mathrm{dni}$ i Ara-C $200 \mathrm{mg} / \mathrm{m}^{2} /$ dobę i.v. przez $7 \mathrm{dni}$ ). Iwosidenib stosowano doustnie $\mathrm{w}$ dawce $500 \mathrm{mg}$ p.o. raz/dobę, a enasidenib w dawce $100 \mathrm{mg}$ p.o. raz/dobę w sposób ciągły od pierwszego dnia chemioterapii indukującej, poprzez konsolidację, a następnie w leczeniu podtrzymującym do 2 lat od chwili rozpoczęcia leczenia. Chorzy kwalifikowani do allo-HSCT nie otrzymywali inhibitora $I D H$ w postępowaniu poprzeszczepowym. Wstępna analiza objęła pierwszych 65 chorych, w tym 27 chorych z mutacją IDH1 leczonych iwosidenibem (mediana wieku 60 lat, zakres 24-76) i 38 chorych $z$ mutacją IDH2 leczonych enasidenibem (median wieku 63 lat, zakres 32-76). Tolerancja chemioterapii skojarzonej $z$ iwosidenibem lub enasidenibem była dobra. Do najczęściej obserwowanych zdarzeń niepożądanych w co najmniej 3. stopniu w grupie leczonej iwosidenibem należały: gorączka neutropeniczna (56\%), wzrost aminotransferaz (11\%) i zapalenie jelita grubego (11\%), a w grupie leczonej enasidenibem gorączka neutropeniczna (63\%), nadciśnienie tętnicze (11\%), zapalenie jelita grubego $(8 \%)$ i wysypka grudkowa (8\%). Śmiertelność w ciągu 30 dni leczenia w grupie leczonej iwosidenibem i enasidenibem wynosiła odpowiednio $7 \%$ i $5 \%$. Mediana czasu do regeneracji granulocytów do wartości co najmniej 500/ $\mu$ l wynosiła 28 dni $\mathrm{w}$ grupie leczonej iwosidenibem i 34 dni w grupie leczonej enasidenibem. Regeneracja liczby PLT do wartości powyżej $50 \mathrm{G} / 1$ wynosiła odpowiednio 28 i 33 dni. Ogólny odsetek CR w obu grupach wynosil odpowiednio $70 \%$ i $62 \%$. Na podstawie wstępnych wyników autorzy konkludują, ze skoja- rzenie standardowej chemioterapii z inhibitorami IDH1/2 jest dobrze tolerowane. Konieczna jest kontynuacja badania i dalsze monitorowanie MRD w celu dokładnej oceny odpowiedzi na leczenie i odległych wyników.

W kolejnym doniesieniu przedstawiono subanalizę $z$ badania 1 fazy, w której oceniono tolerancję i skuteczność enasidenibu u chorych 60-letnich i starszych, $z$ dotychczas nieleczoną AML i wspó1istniejącą mutacją $I D H 2$, którzy nie kwalifikowali się do intensywnej chemioterapii. $\mathrm{W}$ fazie eskalacji początkową dawkę enasidenibu $50 \mathrm{mg} /$ dobę p.o. stopniowo zwiększano do $650 \mathrm{mg} /$ dobę. W fazie ekspansji wszyscy chorzy otrzymali enasidenib w dawce $100 \mathrm{mg} /$ dobę w leczeniu ciaggłym w cyklach 28-dniowych; ORR obejmowal CR, CRi, PR i morfologiczny stan wolny od białaczki (MLFS, morphologic leukemia-free state). Spośród 239 chorych w badaniu I fazy, 37 (15,5\%) miało dotychczas nieleczoną AML z mutacją IDH2. Mediana wieku w tej grupie wynosiła 77 lat (zakres 58-87); ORR wynosił $37,8 \%$, w tym siedmiu chorych (19\%) uzyskało CR. Przy medianie czasu obserwacji 7.9 miesięcy, mediana czasu trwania odpowiedzi wynosiła 12,2 miesiąca, a mediana czasu trwania CR nie została osiągnięta. Mediana OS i EFS w całej grupie chorych wynosiła odpowiednio 10,4 miesiąca i 11,3 miesiąca. Mediana OS w grupie respondentów była ponad 3-krotnie większa niż w grupie chorych, którzy nie odpowiedzieli na leczenie (19,8 miesiąca $v$. 5,4 miesiąca). Do najczęstszych zdarzeń niepożądanych należały: hiperbilirubinemia (30\%), nudności (22\%) zespó1 różnicowania (8\%) i zespół lizy guza (5\%). Wyniki badania wskazują, że leczenie enasidenibem prowadzi do uzyskania trwałych odpowiedzi u blisko $40 \%$ chorych w starszym wieku, którzy nie kwalifikują się do intensywnego leczenia.

Nabyte mutacje genu FLT3, takie jak wewnętrzna tandemowa duplikacja (FLT3-ITD, internal tandem duplication) części przybłonowej oraz mutacja w domenie kinazy tyrozynowej (TKD, tyrosine kinase domain) stwierdzane są u około 30-35\% chorych na AML. Obecność mutacji FLT3-ITD jest niezależnym, niekorzystnym czynnikiem rokowniczym. Na podstawie randomizowanego badania RATIFY, w którym wykazano, że dołączenie inhibitora kinazy FLT3 (M, midostauryna), do standardowej chemioterapii wydłuża OS i EFS u chorych z AML ze wspólistniejącą mutacją FLT3, amerykańska Agencja ds. Żywności i Leków (FDA, Food and Drug Administration) i Europejska Agencja Leków (EMA, European Medicines Agency) zarejestrowały M do leczenia chorych na AML 
z obecnością mutacji FLT3. Obecnie w badaniach klinicznych jest wiele nowych, bardziej selektywnych niż M inhibitorów FLT3.

Krenolanib jest silnym, selektywnym inhibitorem FLT3, który może być bezpiecznie stosowany $\mathrm{w}$ połączeniu ze standardowym leczeniem indukującym i wysokimi dawkami Ara-C w konsolidacji. Na Konferencji ASH w 2017 roku przedstawiono wstępne wyniki badania, w którym oceniono skuteczność krenolanibu w połączeniu ze standardową chemioterapią u 29 60-letnich lub młodszych chorych na AML i z mutacją FLT3 (streszczenie 566). Chorzy otrzymywali standardowe leczenie indukujące $7+3$ (Ara-C $100 \mathrm{mg} / \mathrm{m}^{2}$ przez $7 \mathrm{dni}$ w połączeniu z DNR $90 \mathrm{mg} / \mathrm{m}^{2}[\mathrm{n}=16]$ lub idarubicyna [IDA] $12 \mathrm{mg} / \mathrm{m}^{2}$ [n = 13] przez $3 \mathrm{dni}$ ). Podawanie krenolanibu w dawce $100 \mathrm{mg}$ p.o. 3 razy na dobę rozpoczynano 24 godziny po zakończeniu indukcji i odstawiano 3 dni przed kolejnym kursem chemioterapii. Chorzy w CR otrzymywali do 4 kursów leczenia konsolidującego $\mathrm{z}$ pośrednimi $\left(1 \mathrm{~g} / \mathrm{m}^{2}\right.$ co $12 \mathrm{~h} \mathrm{w}$ dniach 1., 3., 5.) i dużymi $\left(3 \mathrm{~g} / \mathrm{m}^{2}\right.$ co $12 \mathrm{~h}$ w dniach 1., 3., 5.) dawkami Ara-C, odpowiednio, pacjenci w wieku do 60 lat i poniżej 60. roku życia $\mathrm{w}$ skojarzeniu $\mathrm{z}$ krenolanibem stosowanym $\mathrm{w}$ sposób ciągły po zakończeniu konsolidacji. Chorych mających dawcę kwalifikowano do allo-HSCT. W leczeniu podtrzymującym stosowano krenolanib przez 12 miesięcy po zakończeniu konsolidacji lub po allo-HSCT. Po pierwszym cyklu indukującym 21 spośród 29 (72\%) chorych uzyskało CR. W dalszych etapach leczenia CR uzyskało 3 chorych. Ogólny odsetek CR wynosił 83\%. U 16 spośród 24 chorych pozostających w remisji wykonano allo-HSCT. Jeden chory zmarł w CR z powodu powikłań poprzeszczepowych, a jedynie u 2 chorych stwierdzono nawrót. Autorzy konkludują, że dołączenie krenolanibu do standardowej chemioterapii wiąże się $z$ wysokim odsetkiem remisji i stosunkowo niskim odsetkiem nawrotów po allo-HSCT.

$\mathrm{W}$ innym badaniu I/II fazy oceniono skuteczność selektywnego inhibitora FLT3 (fms-like tyrosine kinase 3) - quizartynibu - w połączeniu Z niskodawkowaną chemioterapią AZA lub LD-Ara-C u chorych powyżej 60. roku życia $z$ nowo rozpoznaną AML, MDS oraz przewlekłą białaczką mielomonocytową (CMML, chronic myelomonocytic leukemia) z mutacją FLT3 lub u chorych z AML $F L T 3-I T D(+)$ w pierwszym nawrocie (streszczenie 723). Quizartynib stosowano p.o., w sposób ciągły, w dwóch planowanych dawkach $60 \mathrm{mg}$ lub $90 \mathrm{mg}$ w skojarzeniu $z$ AZA lub LD-Ara-C w standardowych dawkach. Analizą objęto 59 chorych w wieku od 23 do 84 lat (mediana 68 lat). Dawką rekomendowaną obu cytostatyków w badaniu II fazy było $60 \mathrm{mg}$ quizartynibu na dobę; ORR wynosił $73 \%$, w tym $61 \%$ CR. U $12 \%$ chorych stwierdzono remisję MRD(-). W grupie uprzednio nieleczonych chorych obserwowano wyższy odsetek odpowiedzi niż u chorych leczonych w pierwszym nawrocie (ORR odpowiednio 92\% v. 68\%). Mediana czasu do odpowiedzi wynosiła 65 dni (zakres 6-289 dni) w grupie leczonej AZA i 61 dni (zakres 20-256 dni) w grupie leczonej LD-Ara-C. Przy medianie czasu obserwacji wynoszącej 20 miesięcy $26 \%$ chorych nadal pozostawało w CR. Mediana OS w całej grupie chorych wynosiła 20 miesięcy. Do najczęściej obserwowanych zdarzeń niepożądanych w stopniu 3. i 4. według Światowej Organizacji Zdrowia (WHO, World Health Organization) należały: zaburzenia elektrolitowe (hipokaliemia, hiperkaliemia, hipofosfatemia, hiponatremia, hipokalcemia, hipernatremia, hipermagnezemia), obniżenie ciśnienia tętniczego, hiperbilirubinemia i wzrost wartości aminotransferaz, bóle brzucha, biegunka, powikłania kardiologiczne (wydłużenie odstępu QT, migotanie przedsionków, tachykardia zatokowa, płyn w worku osierdziowym). Wyniki badania wskazują, że połączenie quizartynibu $z$ niskodawkowaną chemioterapią (AZA lub LD-Ara-C) charakteryzuje się wysoką skutecznością u chorych na AML $z$ mutacją FLT3.

Mierzalna MRD to obecność przetrwałych komórek białaczkowych po chemioterapii w liczbie poniżej progu detekcji standardowych metod morfologicznych. Warunkiem monitorowania MRD jest precyzyjne określenie cech komórki białaczkowej, które w chwili rozpoznania odróżniają ją od prawidłowych komórek hematopoezy. Wyniki wstępnych badań wskazują, że obecność MRD w CR jest dodatkowym niekorzystnym czynnikiem prognostycznym u chorych na AML. Na konferencji ASH w 2017 roku wiele uwagi poświęcono roli nowoczesnych technik molekularnych, takich jak RQ-PCR i NGS, w monitorowaniu MRD u chorych na AML. Francuska grupa ALFA (Acute Leukemia French Association) oceniła przydatność i wartość prognostyczną monitorowania ekspresji genu WT1 w oznaczaniu MRD u chorych poniżej 60. roku życia (streszczenie 29). Spośród 713 chorych leczonych w ramach badania ALFA-0702 nadmierną ekspresję $W T 1$ w chwili rozpoznania stwierdzono u 539 chorych $(75,6 \%)$. Poziom MRD po indukcji oceniano metodą RQ-PCR. Spośród 539 chorych z nadmierną ekspresją WT1 (WT1+) 473 (87,7\%) uzyskało CR. Spośród nich u 339 (71,7\%) chorych przeprowadzono ocenę MRD po leczeniu indukującym. U 279 chorych nie stwierdzono obecności 
MRD (MRD-) po indukcji, natomiast u 60 chorych MRD występowała (MRD+). Obecność MRD po indukcji była czynnikiem predykcyjnym nawrotu choroby. Skumulowany odsetek nawrotów w ciągu 4 lat u chorych MRD(-) był istotnie niższy niż u chorych MRD(+) i wynosił odpowiednio $36,5 \%$ oraz 69,2\% (HR 2,88; CI 1,93-4,29; p < 0,001). $\mathrm{W}$ analizie wielowariantowej obecność MRD po indukcji była niezależnym czynnikiem predykcyjnym związanym $\mathrm{z}$ wyższym odsetkiem nawrotów (HR 2,15; CI 1,41-3,29; $\mathrm{p}<0,001$ ).

Brak MRD po indukcji wiązał się również $z$ istotnie większymi odsetkami 4-letniego RFS (60,9\% v. 24,9\%; HR 2,69; CI 1,89-3,83; $\mathrm{p}<0,001)$ i OS $(71,6 \%$ v. 43,3\%; HR 2,34; CI $1,56-3,51 ; \mathrm{p}<0,001)$ w porównaniu $z$ chorymi $\mathrm{MRD}(+)$. W analizie wielowariantowej $\mathrm{MRD}(-)$ była niezależnym czynnikiem związanym $z$ dłuższym RFS (HR 2,12; CI 1,47-3,07; p = 0,001) i OS (HR 1,79; CI 1,18-2,73; $\mathrm{p}<0,001$ ).

W badaniu grupy niemieckiej oceniono skuteczność monitorowania MRD za pomocą ilościowej oceny transkryptu genu nukleofozminy 1 (NPM1) u 611 chorych poniżej 60 . roku życia z mutacją NPM1 (streszczenie 183). Chorzy byli leczeni według $1 \mathrm{z} 4$ protokołów AMLSG (AMLHD98A, $\mathrm{n}=46$; AMLSG 07-04, $\mathrm{n}=199$; AMLSG 09-09, $\mathrm{n}=256$; AMLSG 16-10, $\mathrm{n}=110$ ). Stosunek ilości zmutowanego transkryptu $N P M 1^{\text {mut }}$ do transkryptów $A B L 1$ $\times 10^{4}$ (NPM1 $\left.{ }^{\text {mut }} \mathrm{TL}\right)$ oceniono metodą RQ-PCR Z czułością na poziomie $10^{-5}-10^{-6}$. Wykazano, że redukcja $N P M 1^{\text {mut }}$ TL o ponad 2 log koreluje $z$ istotnie dłuższym OS $(p<0,0001)$ i niższym CIR $(\mathrm{p}=0,0002)$. W porównaniu $z$ chorymi $\mathrm{MRD}(+)$ brak MRD po 2 cyklach chemioterapii wiązał się z niższym CIR w ciągu 4 lat $(10 \%$ v. $40 \%$; $\mathrm{p}<0,0001)$ i wyższym odsetkiem 4-letnich przeżyć ( $82 \%$ v. 63\%; $\mathrm{p}=0,01)$. W analizie wielowariantowej wykazano, że negatywizacja MRD po 2 cyklach chemioterapii jest niezależnym czynnikiem prognostycznym dłuższych OS ( $\mathrm{p}=0,02)$ i RFS $(\mathrm{p}=0,001)$, niezależnie od obecności mutacji FLT3-ITD i DNMT3A.

W sesji LBA przedstawiono niezwykle ciekawe wyniki badania grupy HOVON-SAAK (Dutch-Belgian Hemato-Oncology Cooperative Group and the Swiss Group for Clinical Cancer Research), w którym oceniono przydatność metody NGS do monitorowania MRD u chorych na AML (LBA-5); NGS ma przewagę nad standardowymi metodami molekularnymi, gdyż umożliwia ocenę szerokiego zakresu mutacji genetycznych związanych z AML w pojedynczym badaniu. Mutacje specyficzne dla klonu białaczkowego przetrwałe w szpiku kostnym w CR po chemioterapii przypuszczalnie są źródłem nawrotu choroby, jednak przetrwałe mutacje mogą być również odzwierciedleniem klonalnej hematopoezy, analogicznej do CHIP zależnej od wieku, obecnej u osób zdrowych. Dotychczas nie wiadomo, które przetrwałe po chemioterapii mutacje somatyczne przyczyniają się do nawrotu choroby. $\mathrm{W}$ badaniu metodą NGS oceniono panel 54 genów u 482 chorych na AML poniżej 65. roku życia leczonych w ramach badan klinicznych grupy HOVON-SAKK. Badanie wykonywano w chwili rozpoznania i w $\mathrm{CR}$ po 2 cyklach leczenia indukującego. W celu ustalenia i przetestowania definicji MRD w przypadku wykorzystania metody NGS chorych podzielono na dwie podgrupy — próbną $(\mathrm{n}=283)$ i walidacyjną $(\mathrm{n}=147)$. Somatyczne mutacje typu driver $\mathrm{w}$ chwili rozpoznania stwierdzono u $89,2 \%$ chorych. U $51,4 \%$ chorych wykazano obecność przetrwałych mutacji o wysoce zmiennej częstości alleli wariantowych (VAF 0.0002-0.47) w szpiku kostnym w CR. Do najczęściej obserwowanych mutacji przetrwałych w CR należały DNMT3A (78,7\%), TET2 (54,2\%), ASXL1 (51,6\%) (tzw. mutacje DTA). Obecność przetrwałych mutacji DTA w CR nie wiązała się $z$ ryzykiem nawrotu $\mathrm{w}$ żadnym punkcie odcięcia VAF, co wskazuje, że odzwierciedlają one raczej stan klonalnej hematopoezy niż chorobę resztkową.

$\mathrm{W}$ podgrupie chorych na AML $z$ przetrwałymi mutacjami typu DTA jedynie obecność dodatkowych przetrwałych mutacji innych niż DTA miała związek z ryzykiem nawrotu (CIR 76,4\% v. 39,4\%; $\mathrm{p}=0,002)$. Na podstawie obserwacji $\mathrm{MRD}(+)$ w grupie próbnej, oznaczanej za pomocą NGS, zdefiniowano ją jako obecność przetrwałych mutacji innych niż DTA. Obecność tak zdefiniowanej MRD wiązała się $z$ wysokim ryzykiem nawrotu zarówno w grupie próbnej (HR 1,85; 95\% CI 1,27-2,70; $\mathrm{p}=0,001$ ), jak i walidacyjnej (HR 2,81; $95 \% \mathrm{CI}$ $1,64-4,79 ; \mathrm{p}<0,001)$. Obecność MRD wykrywanej metodą NGS korelowała również z krótszym OS; $\mathrm{w}$ analizie wielowariantowej wykazano, że jest ona niezależnym czynnikiem predykcyjnym dla CIR (HR 1,89; 95\% CI 1,34-2,65; p < 0,001) i prognostycznym dla OS (HR 1,64; $95 \%$ CI 1,18-2,27; $\mathrm{p}=0,003)$.

W podsumowaniu doniesień $z$ ostatniej konferencji ASH należy podkreślić, że skojarzenie standardowej chemioterapii z nowymi lekami w celu poprawy jakości remisji jest przedmiotem licznych badań. Współczesne standardy leczenia obejmują skojarzenie nowych terapii celowanych ze standardową chemioterapią w wybranych grupach genetycznych. Monitorowanie MRD jest niezależnym czynnikiem prognostycznym w leczeniu AML. Metody molekularne, w tym NGS i RQ-PCR, 
mają coraz większe zastosowanie w ocenie ryzyka nawrotu w AML.

\section{Ostra białaczka limfoblastyczna} dr hab. n. med. Anna Czyż

Podczas konferencji ASH w 2017 roku zaprezentowano wyniki ponad 400 prac $z$ zakresu biologii, diagnostyki i leczenia chorych na ALL. Doniesienia poświęcone leczeniu dotyczyły trzech głównych zagadnień - optymalizacji terapii prowadzonej na podstawie monitorowania MRD, skuteczności i bezpieczeństwa przeciwciał monoklonalnych stosowanych w skojarzeniu $z$ chemioterapią lub TKI w przypadku ALL-Ph(+) oraz możliwości bezpiecznej deeskalacji chemioterapii w grupie starszych chorych, związanej $z$ wprowadzeniem do leczenia przeciwciał monoklonalnych i TKI kolejnych generacji. Liczne prace były również poświęcone skuteczności i bezpieczeństwu immunoterapii z zastosowaniem CAR-T.

Wieloośrodkowa Niemiecka Grupa Badawcza ds. Ostrej Białaczki Limfoblastycznej u Dorosłych (GMALL, German Multicenter Study Group for Adult $A L L$ ) przedstawiła ważne badanie obejmujące ponad 2000 chorych leczonych według programu terapeutycznego GMALL 07/03, w którym oceniano różne elementy strategii terapeutycznej opartej na molekularnej ocenie MRD (streszczenie 139). Jednym $z$ ważnych celów analizy było porównanie wyników wczesnego i opóźnionego HSCT u chorych $z$ MRD powyżej $10^{-4} \mathrm{w} 16$. tygodniu leczenia. Porównano OS i czas utrzymywania się remisji (RD, remission duration) po HSCT u chorych, którzy przed transplantacją zostali poddaniu leczeniu konsolidującemu, oraz poddanych transplantacji bezpośrednio po indukcji. Zgodnie $z$ protokołem GMALL 07/03 MRD oceny dokonywano za pomocą badania rearanżacji receptora T-komórkowego (TCR, T-cell receptor) lub genów immunoglobulinowych metodą RQ-PCR, które wykonywano w laboratorium referencyjnym w Kolonii. Mediana wieku chorych włączonych do analizy wyniosła 34 lata (zakres 16-65); CR uzyskało 90\% chorych, a OS i RD w całej badanej grupie wyniosły po 5 latach odpowiednio $60 \%$ i $64 \%$. Odsetek chorych, u których wykonywano molekularną ocenę MRD, wzrastał w okresie, w którym wdrożono protokół - z 53\% w latach 2003-2009 do 69\% w latach 2010-2016. Molekularną CR (MolCR), ocenianą metodą o czułości $10^{-4}$, uzyskano u $59 \%$ chorych z grupy, w której wykonano badanie MRD. Brak odpowiedzi molekularnej (MolF, molecular failure), definiowany jako obecność MRD na poziomie ponad $10^{-4}$, stwierdzono u $18 \%$ chorych; OS po 5 latach osiągnęło $83 \%$ chorych $z$ MolCR oraz $43 \%$ chorych z MolF (p < 0,0001), a 5-letnie RD wyniosło odpowiednio $80 \%$ i $38 \%$ w tych grupach ( $<<0,0001)$. U 62\% chorych $z$ MolF przeprowadzono HSCT w CR1; OS i RD tych chorych były znamiennie lepsze niż chorych $z$ MolF, którzy nie byli leczeni z zastosowaniem HSCT w CR1 (5-letnie OS 53\% $v .28 \%$, a 5-letnie RD $56 \%$ v. 9\%). Porównano również OS chorych $z$ MolF poddanych wczesnemu HSCT bez poprzedzających transplantację kolejnych cykli leczenia $z$ OS chorych, u których po stwierdzeniu MolF zastosowano konsolidację remisji; OS w grupie chorych poddanych wczesnemu HSCT wyniosło $34 \%$ po 5 latach, a w grupie chorych leczonych opóźnionym HSCT - 63\% ( $\mathrm{p}=0,002)$. Autorzy odnotowali jednak, że tylko u 1 z 7 chorych na pre-B-ALL z MolF uzyskano MolCR po standardowej konsolidacji opartej na chemioterapii. Natomiast w grupie 11 chorych $z$ MolF, u których w konsolidacji remisji zastosowano blinatumomab, aż u 10 uzyskano eradykację MRD, tj. MolCR. Autorzy we wnioskach podkreślają, że choć HSCT przynosi korzyść chorym $z$ MolF, to opóźnienie transplantacji może być korzystne, zwłaszcza jeżeli w eradykacji MRD stosuje się nowoczesną terapię celowaną.

Leczenie przeciwciałami monoklonalnymi w różnych grupach chorych na ALL z komórek prekursorowych limfocytów B było kolejnym tematem licznych prac prezentowanych na konferencji ASH w 2017 roku. Skuteczność inotuzumabu ozogamycyny (INO), monoklonalnego przeciwciała anty-CD22 sprzężonego $z$ ozogamycyną, pochodną kalicheamycyny, oceniano w kilku badaniach I-III fazy prowadzonych w MD Anderson Cancer Center. Wyniki leczenia INO chorych na oporne i nawrotowe (R/R, refractory/relapsed) postaci ALL, włączonych do III fazy badania INO-VATE (InO was administered to adult patients with $R / R C D 22+$ $B$-cell ALL in a phase 1/2 [B1931010] study, and a phase 3), zespół badaczy z tego ośrodka opublikował już w 2016 roku. Na konferencji ASH w 2017 roku zostały zaprezentowane wyniki analizy danych $z$ tego badania, której celem była ocena wpływu nasilenia ekspresji CD22 na komórkach białaczkowych na skuteczność leczenia INO (streszczenie 1272). Ekspresję CD22 na nie mniej niż 90\% blastów stwierdzono u $65 \%$ chorych. W tej grupie chorych odnotowano największą korzyść z leczenia INO. W porównaniu $z$ grupą kontrolną, leczoną standardową chemioterapią, u chorych leczonych INO z ekspresją CD22 na co najmniej $90 \%$ blastach stwierdzono znamiennie wyższy odsetek CR (78\% v. 35\%), dłuższy czas trwania odpowiedzi (mediana 5,4 v. 3,1 miesiąca) i dłuższe OS (mediana 8,4v. 5,4 miesiąca). 
W grupie chorych $z$ ekspresją CD22 na mniej niż $90 \%$ blastów te różnice nie były znamienne statystycznie (CR 66\% v. 31\%; mediana CRD 3,9 v. 5,8 miesiąca, mediana OS 5,7 v. 7,7 miesiąca). Ekspresja CD22 na blastach nie wpływała na występowanie zdarzeń niepożądanych związanych ze stosowaniem INO. W podsumowaniu autorzy podkreśli, że choć największą korzyść $z$ leczenia INO odnoszą chorzy $z$ wysoką ekspresją CD22 na co najmniej $90 \%$ blastów, to korzystny profil skuteczności i bezpieczeństwa immunoterapii stwierdza się niezależnie od nasilenia ekspresji CD22 na tych komórkach.

Celem badania I/II fazy prezentowanego przez Short i wsp. (streszczenie 2576) była natomiast ocena wyników leczenia INO starszych chorych na nowo rozpoznaną pre-B ALL, stosowanego $\mathrm{w}$ skojarzeniu $\mathrm{z}$ chemioterapią, podawaną według programu mini-hyper-CVAD (w porównaniu ze standardowym programem hyper-CVAD: zmniejszenie dawek cyklofosfamidu i deksametazonu o $50 \%$, metotreksatu o $75 \%$, pominięcie antracykliny oraz zmniejszenie dawki Ara-C do 4 podań po $0,5 \mathrm{~g} /$ $/ \mathrm{m}^{2}$ ); INO stosowano w dawce $1,3 \mathrm{mg} / \mathrm{m}^{2} \mathrm{w} 3$. dniu pierwszego cyklu, a następnie $1 \mathrm{mg} / \mathrm{m}^{2} \mathrm{w} 3$. dniu cykli od drugiego do czwartego. Dodatkowo u chorych z ekspresją CD20 na blastach stosowano rytuksymab. Wszyscy chorzy otrzymywali leczenie dokanałowe $\mathrm{w}$ ramach profilaktyki zajęcia ośrodkowego układu nerwowego (OUN). Przez 3 lata stosowano leczenie podtrzymujące remisję według programu POMP (6-merkaptopuryna, wikrystyna, metotreksat, prednizon). Do badania włączono 52 chorych w wieku od 60 do 81 lat (mediana 68 lat). Remisję całkowitą uzyskano u $97 \%$. Dodatkowo u 96\% chorych stwierdzono MRD(-), ocenianą metodą 6-kolorowej cytometrii przeływowej. Śmiertelność w czasie leczenia była niska, równa zaledwie $4 \%$ po 60 dniach od rozpoczęcia leczenia. U 4 chorych (8\%), w tym u 1 po allo-HSCT, w okresie obserwacji rozwinęła się choroba zarostowa żył wątrobowych (VOD, veno-occlusive disease). Mediana czasu obserwacji w badaniu wyniosła 29 miesięcy. Szacowane OS i RD po 3 latach wyniosły odpowiednio 56\% i 76\%. Stwierdzono znamienną poprawę OS chorych leczonych chemioterapią według programu R-mini-hyper-CVD w skojarzeniu $z$ INO w porównaniu $z$ przeżyciem chorych $z$ grupy historycznej, leczonych według programu R-hyper-CVAD (54\% v. 32\%; $\mathrm{p}=0,004)$. Potwierdzenie tej obserwacji w prospektywnym badaniu III fazy może się przyczynić do dalszej optymalizacji leczenia starszych chorych na ALL-Ph(-).

Wprowadzenie do leczenia TKI II i III generacji stwarza nadzieję na uzyskanie długotrwałych remisji u starszych chorych na ALL-Ph(+), którzy nie kwalifikują się do chemioterapii i allo-HSCT. Włoska grupa GIMEMA (Gruppo Italiano Malattie Ematologiche Maligne Dell' Adulto) zaprezentowała wyniki prospektywnego wieloośrodkowego badania II fazy GIMEMA LAL1811, którego celem była ocena skuteczności i bezpieczeństwa stosowania ponatynibu $\mathrm{w}$ skojarzeniu ze steroidami u chorych na ALL-Ph(+) w starszym wieku lub o obniżonej sprawności ogólnej (streszczenie 99). Ponatynib podawano w dawce dobowej $45 \mathrm{mg}$ przez 8 kolejnych cykli trwających 6 tygodni. Steroidy były podawane od dnia -14 . do 29 . dnia pierwszego cyklu. Dodatkowo co 4 tygodnie dokanałowo podawano MtX, cytarabinę i deksametazon. Do badania włączono 44 chorych w wieku od 27 do 85 lat (mediana 68 lat). W wyniku steroidoterapii, stosowanej w fazie przedleczenia, u 14 spośród 39 chorych wystąpiła redukcja odsetka blastów we krwi obwodowej. Całkowitą remisję hematologiczną uzyskano u $95 \%$ chorych już po pierwszym cyklu leczenia. Po 8. cyklu $90 \%$ chorych pozostawało w CHR.Leczenie wstrzymano z powodu toksyczności tylko u 1 chorego. Ocenę molekularną po 8. cyklu przeprowadzono u 33 chorych. Całkowitą remisję molekularną uzyskało $61 \%$ chorych. Szacowane OS po roku wyniosło $87 \%$, przy medianie obserwacji wynoszącej 11 miesięcy. W badanej grupie stwierdzono 36 zdarzeń niepożądanych związanych ze stosowaniem ponatynibu, $z$ których jedynie 13 uznano za poważne. Analizę mutacji $B C R / A B L 1$ przeprowadzono u 15 chorych po 8 cyklach leczenia. Tylko u 1 chorego wykazano mutację T315I. Uzyskane wyniki wskazują na wysoką skuteczność i względne bezpieczeństwo stosowania ponatynibu u chorych w starszym wieku lub o obniżonej sprawności. Skuteczność kliniczna leczenia ponatynibem wydaje się wiązać $z$ szybką i głęboką redukcją klonu białaczkowego $\mathrm{Ph}(+)$, którą uzyskano u większości chorych już po 4 tygodniach leczenia.

Połączenie nowych form immunoterapii $z$ leczeniem TKI kolejnych generacji otwiera droge próbom poprawy dotychczas złych wyników leczenia chorych na R/R ALL-Ph(+). Na konferencji ASH w 2017 roku zaprezentowano wyniki skojarzonego leczenia blinatumomabem i TKI (streszczenie 2598) oraz INO $z$ bosutynibem (streszczenie 143). Skojarzenie blinatumomabu, który stosowano maksymalnie przez 4 cykle leczenia, $z$ dazatynibem, bosutynibem lub ponatynibem pozwolito na uzyskanie CR u ponad $60 \%$ chorych, a mediana OS przekroczyła 12 miesięcy. Leczenie INO w skojarzeniu $z$ bosutynibem zastosowano w ramach badania I/II fazy u chorych na R/R ALL-Ph(+) 
oraz w kryzie limfoblastycznej CML. Bosutynib podawano $\mathrm{w}$ dawce dobowej od 300 do $500 \mathrm{mg}$, INO stosowano w cyklach 4-tygodniowych, w dawce $0,8 \mathrm{mg} / \mathrm{m}^{2} 1$. dnia, a następnie $0,5 \mathrm{mg} / \mathrm{m}^{2} \mathrm{w}$ dniach 8. i 15. pierwszego cyklu. U chorych, którzy uzyskali odpowiedź, INO podawano raz na 4 tygodnie w kolejnych cyklach leczenia. W czasie ostatniej konferencji ASH zaprezentowano wyniki I fazy badania, której celem było ustalenie maksymalnej tolerowanej dawki bosutynibu w tej kombinacji. Do badania dotychczas włączono 12 chorych na R/R $\mathrm{ALL}-\mathrm{Ph}(+)$ i 2 chorych na CML. Mediana wieku chorych wyniosła 62 lata (zakres od 19 do 74 lat). Chorzy otrzymali wcześniej od jednej do trzech innych terapii ratunkowych. Sześciu $z$ nich było wcześniej poddanych allo-HSCT, a u 8 stwierdzono mutację domeny kinazy ABL1. U żadnego chorego leczonego bosutynibem w dawce $300 \mathrm{mg} /$ dobę nie obserwowano toksyczności ograniczającej dawkę (DLT, dose-limiting toxicity). U 1 z 6 chorych leczonych dawką $400 \mathrm{mg}$ /dobę stwierdzono DLT pod postacią wysypki skórnej 3. stopnia. Ocena DLT w odniesieniu do dawki $500 \mathrm{mg} /$ dobę nie jest jeszcze zakończona. Dotychczas u żadnego $z$ chorych nie obserwowano objawów VOD. Remisję hematologiczną uzyskano u 11 z 14 chorych (79\%), w tym u 10 z 11 (91\%) stwierdzono CCR, a u 6 z 11 (55\%) - całkowitą odpowiedź molekularną (CMR, complete molecular response). Mediana EFS wyniosła 8,1 miesiąca, a OS - 8,2 miesiąca. U 5 chorych przeprowadzono allo-HSCT; $4 \mathrm{z}$ nich żyje w CR. Wyniki te pozwalają wnioskować, że skojarzenie bosutynibu $z$ INO charakteryzują korzystny profil bezpieczeństwa i znaczna skuteczność kliniczna w R/R ALL-Ph(+).

W podsumowaniu omówionych doniesień warto podkreślić, że zaprezentowane na konferencji ASH w 2017 roku postępy w leczeniu chorych na ALL wydają się szczególnie znaczące w starszych grupach wiekowych i w przypadku choroby przebiegającej z obecnością chromosomu Ph. Ogromne nadzieje wiązane są również z możliwościami, jakie niesie ze sobą immunoterapia, zarówno w przypadku R/R ALL, jak i eradykacji MRD przed procerdurą allo-HSCT.

\section{Nabyte skazy krwotoczne \\ prof. dr hab. n med. Jacek Treliński}

W sesji LBA przedstawiono wyniki randomizowanego badania III fazy HERCULES (Phase III Trial With Caplacizumab in Patients With Acquired Thrombotic Thrombocytopenic Purpura), słuzącego ocenie skuteczności i bezpieczeństwa leczenia kaplacizumabem nabytej postaci zakrzepowej plamicy małopłytkowej (aTTP, acquired thrombotic thrombocytopenic purpura). Kaplacizumab jest niewielkim fragmentem przeciwciała (nanobody) skierowanym przeciwko domenie A1 czynnika von Willebranda (vWF, von Willebrand factor). Lek ten, uniemożliwiając interakcje między ultradużymi multimetrami vWF a GP (glikoproteiną) Ib PLT, wpływa na jeden $z$ podstawowych mechanizmów patogenetycznych tworzenia się mikrozakrzepów w aTTP. Do badania włączono 145 pacjentów, którzy po rozpoznaniu ostrego epizodu aTTP i po wykonaniu jednej procedury wymiennej transfuzji osocza (TPE, therapeutic plasma exchange) byli w losowy sposób przydzieleni do grupy otrzymującej placebo (73 chorych) lub kaplacizumab (72 chorych). Jednocześnie wszyscy badani otrzymywali leczenie immunosupresyjne kortykosteroidami. Pierwszą dawkę przeciwciała podawano i.v., a kolejne s.c. raz/dobę (10 mg), w okresie wykonywania TPE, a następnie $\mathrm{w}$ czasie 30 dni po ich zakończeniu. U niektórych pacjentów ( $\mathrm{z}$ utrzymującą się niską aktywnością ADAMTS13 [a disintegrin-like and metalloprotease with thrombospondin type I repeats 13]) okres terapii przedłużano o kolejne 4 tygodnie. $\mathrm{Na}$ koniec, po ostatniej iniekcji leku, obowiązywał 28-dniowy okres obserwacji. Pierwszorzędowym punktem końcowym badania była ocena czasu do uzyskania wzrostu liczby PLT do wartości nie mniejszej niż $150 \mathrm{G} / \mathrm{l}$, z następowym zaprzestaniem TPE w okresie do 5 dni (czas do remisji choroby). Drugorzędowymi punktami końcowymi były między innymi ocena śmiertelności związanej z aTTP, ocena odsetka wczesnych nawrotów, ocena odsetka poważnych powikłań zakrzepowych, ocena odsetka chorych opornych na terapię, a także ocena czasu do normalizacji wybranych markerów biochemicznych uszkodzenia tkanek.

Leczenie kaplacizumabem spowodowało istotne skrócenie czasu do uzyskania remisji choroby (współczynnik czasu do normalizacji liczby PLT placebo $v$. kaplacizumab 1,55 ; 95\% CI 1,1-2,2; $\mathrm{p}<0,01)$. W grupie otrzymującej przeciwciało stwierdzono 74-procentową redukcję śmiertelności $z$ wiązanej $z$ aTTP $(0 v .3$ chorych $)$, a także znaczące zmniejszenie odsetka wczesnych nawrotów (9v. 28 chorych; $\mathrm{p}<0,0001)$. U żadnego pacjenta leczonego kaplacizumabem nie obserwowano oporności na terapię $\mathrm{w}$ przeciwieństwie do 3 chorych otrzymujących placebo $(\mathrm{p}=0,057)$. Terapia kaplacizumabem skutkowała szybszą normalizacją dehydrogenazy mleczanowej, troponiny sercowej (cTn, cardiac troponin) czy kreatyniny. Ponadto odnotowano 38-procentowe zmniejszenie średniej liczby TPE $(5,8 v .9,4), 41$-procentową redukcję objętości prze- 
toczonego osocza (21,3 v. 35,9 1), 65-procentowe zmniejszenie liczby dni pobytu na oddziale intensywnej terapii (3,4 v. 9,7 dnia), a także 31-procentowe skrócenie całkowitego czasu hospitalizacji (9,9 $v .14,4 \mathrm{dni})$. W obu badanych grupach stwierdzono podobny odsetek chorych u których występowały objawy niepożądane $(97,3 \%$ v. 97,2\%). Na uwage zasługuje fakt częstszego występowania powikłań krwotocznych u pacjentów leczonych kaplacizumabem $(45,6 \%$ v. $23,3 \%)$. Należy podkreślić, że były to przede wszystkim niegroźne krwawienia skórno-śluzówkowe z nosa i dziąseł oraz obecność sińców. Wyniki przedstawionego badania wskazują, że kaplacizumab jest skuteczną i bezpieczną opcją terapeutyczną w aTTP (streszczenie LBA-1).

W trakcie 59. Konferencji ASH wiele uwagi poświęcono nabytym zaburzeniom hemostazy w przebiegu różnych nowotworów układu krwiotwórczego. Na uwagę zasługuje praca (streszczenie 1743), w której oceniono ryzyko poważnego krwawienia u chorych na CLL/chłoniaka $z$ małych limfocytów (SLL, small lymphocytic lymphoma) i chłoniaka $z$ komórek płaszcza (MCL, mantle cell lymphoma) leczonych ibrutynibem. Wcześniejsze wyniki badań wskazywały na zwiększone ryzyko krwawień u chorych leczonych ibrutynibem, co spowodowało umieszczenie stosownego ostrzeżenia w Charakterystyce Produktu Leczniczego (ChPL). Przeanalizowano dane $z 4$ randomizowanych badań klinicznych: RESONATE (Ibrutinib versus Ofatumumab in Patients with Relapsed or Refractory Chronic Lymphocytic Leukemia) (ibrutynib $v$. ofatumumab w R/R CLL/SLL), RESONATE-2 (ibrutynib $v$. chlorambucyl u starszych nieleczonych chorych na CLL/SLL), HELIOS (Health for Life in Singapore Study) (bendamustyna i R \pm ibrutynib w R/R CLL/ /SLL) i RAY (ibrutynib $v$. temsirolimus w R/R MCL). Sumarycznie w tych 4 badaniach grupa chorych leczonych ibrutynibem wynosiła 756 , a leczonych komparatorem - 749. Dodatkowo przeanalizowano 1768 chorych leczonych ibrutynibem (całkowita pula ibrutynibu); w tej puli mieścili się pacjenci Z wyżej wymienionych badań randomizowanych oraz $z$ badań klinicznych, w których stosowano ibrutynib $z$ innych wskazań (chłoniak rozlany $z$ dużych komórek B, chłoniak strefy brzeżnej, FL i makroglobulinemia Waldenströma). Wśród pacjentów leczonych w ramach badań randomizowanych odsetek chorych $z$ objawami poważnego krwawienia był wyższy w grupie otrzymującej ibrutynib $(4,4 \%)$ niż komparator $(2,8 \%)$. Jednak po uwzględnieniu poprawki wynikającej $z$ faktu dłuższej ekspozycji chorych na ibrutynib niż komparator okazało się, że odsetek poważnych krwawień był identyczny w obu badanych grupach i wynosił 3,3/1000 pacjentów/ /miesiąc. Z kolei w grupie wszystkich 1768 chorych leczonych ibrutynibem stwierdzono $4,1 \%$ poważnych krwawień. Odsetek ten po dostosowaniu do czasu terapii wynosił 3,8/1000 pacjentów/miesiąc.

Ważnym aspektem badania była ocena wpływu leków przeciwzakrzepowych i/lub przeciwpłytkowych (AC/AP, anticoagulant/antiplatelet agents) na ryzyko poważnych krwawień u pacjentów przyjmujących ibrutynib. Takie leczenie towarzyszące otrzymywała połowa badanych. W analizie jednoczynnikowej dodanie do terapii ibrutynibem lub komparatorem AC/AP wiązało się z podobnym zwiększeniem odsetka powikłań krwotocznych w obu badanych grupach. Po uwzględnieniu korekty związanej $z$ czasem terapii AC/AP stwierdzono, że zwiększenie względnego ryzyka poważnych krwawień związane $z$ dołączeniem AC/AP wynosi 1,2 (95\% CI 0,6-2,5) w grupie chorych leczonych ibrutynibem (w 4 badaniach randomizowanych), $2,4(95 \%$ CI 1,0-5,6) w grupie chorych leczonych komparatorem i 1,9 (95\% CI 1,2-3,0) w grupie całkowitej puli leczonych ibrutynibem.

Autorzy wnioskują, że po uwzględnieniu czasu ekspozycji odsetek poważnych powikłań krwotocznych jest podobny między chorymi leczonymi ibrutynibem i komparatorem. Ze względu na podobny wzrost odsetka krwawień po dołączeniu leków AC/ /AP w grupach leczonych ibrutynibem i komparatorem można wnosić, że ibrutynib nie modyfikuje znacząco ryzyka poważnych krwawień związanych $\mathrm{z}$ zastosowaniem AC/AP.

Interesująca jest praca (streszczenie 2363), w której podjęto się oceny częstości występowania nabytego niedoboru czynnika krzepnięcia $\mathrm{X}$ (FX, factor $X)$ w pierwotnej amyloidozie (AL) i jego wpływu na rokowanie. Do badania zakwalifikowano 104 chorych, u których przeanalizowano aktywność FX w czasie rozpoznania. U 94 aktywność FX wynosiła co najmniej 50\%, natomiast u 10 stwierdzono wartości poniżej 50\%. Tylko u 2 pacjentów zaobserwowano aktywność FX poniżej 10\%. U żadnego badanego nie występowały powikłania krwotoczne w czasie 12 miesięcy od momentu pierwszego pomiaru aktywności FX. W porównaniu $z$ chorymi o prawidłowej aktywności FX grupa pacjentów o zmniejszonej aktywności charakteryzowała się bardziej zaawansowanym stadium choroby $(\mathrm{p}=0,05)$ i wyższymi wartościami markerów uszkodzenia mięśnia sercowego - N-końcowego fragmentu propeptydu natriuretycznego typu B (NT-proBNP, $N$-terminal pro-B-type natriuretic peptide) i cTnT. Mediana OS u chorych $z$ niedoborem FX była znamiennie niższa (9,3 v. 118,1 miesiąca; 
$\mathrm{p}=0,008)$ niż u pacjentów, u których aktywność FX pozostawała w nomie. W analizie wieloczynnikowej jedynym parametrem o istotnym wpływie na OS był stopień zawansowania choroby. Autorzy uważają, że niedobór FX, choć rzadki, może być dobrym markerem zaawansowania pierwotnej AL.

Trombofilie i żylna choroba zakrzepowo-zatorowa

prof. dr hab. n. med. Krystyna Zawilska

Diagnostyka i leczenie żylnej choroby

zakrzepowo-zatorowej

W trakcie opracowania przez ASH, wspólnie z McMaster University w Kanadzie, są wytyczne dotyczące diagnostyki, profilaktyki i leczenia żylnej choroby zakrzepowo-zatorowej (VTE, venous thromboembolism). Powołano zespół koordynujący pod kierunkiem prof. Adama Cukera i dziesięć 10-osobowych grup międzynarodowych ekspertów, których celem jest przygotowanie wytycznych dotyczących następujących zagadnień: a) zapobiegania VTE u pacjentów zabiegowych; b) zapobiegania VTE u pacjentów niezabiegowych; c) diagnostyki VTE; d) leczenia zakrzepicy żył głębokich (DVT, deep vein thrombosis) i zatorowości plucnej (PE, pulmonary embolism); e) optymalizacji leczenia przeciwkrzepliwego; f) trombofilii; g) VTE u kobiet w ciąży; h) VTE u chorych na nowotwory złośliwe; i) VTE w populacji dzieci i młodzieży; j) małopłytkowości poheparynowej. Zamieszczone na stronie internetowej ASH robocze wersje tych zaleceń (http://www.hematology.org/Clinicians/ /Guidelines-Quality/Guidelines.aspx) są przeznaczone do publicznej dyskusji.

Przykładowe zalecenia dotyczące zapobiegania VTE w podróży trwającej ponad 4 godziny: a) używania pończoch o stopniowanym ucisku (PSU) nie zaleca się u osób, u których nie występują uznane czynniki ryzyka zakrzepowego (zalecenie „słabe”, brak dowodów na skuteczność). W badaniach stosowano podkolanówki o ucisku $10-20 \mathrm{~mm} \mathrm{Hg}$ albo pończochy o ucisku $20-30 \mathrm{~mm} \mathrm{Hg}$; b) stosowania heparyn drobnocząsteczkowych (LMWH, low-molecular-weight heparin) nie zaleca się u osób, u których nie występują uznane czynniki ryzyka zakrzepowego (zalecenie „słabe”, brak dowodów na skuteczność); c) stosowania kwasu acetylosalicylowego (ASA, acetylsalicylic acid) nie zaleca się u osób, u których nie występują uznane czynniki ryzyka zakrzepowego (zalecenie „słabe”, brak dowodów na skuteczność). Uwaga! U osób preferujących zapobieganie VTE zaleca się stosowanie PSU, które jednocześnie zmniejszają skłonność do obrzęków kończyn dolnych tworzących się podczas podróży; d) u osób obciążonych zwiększonym ryzykiem zakrzepowym (przebyty niedawno zabieg operacyjny, przebyta VTE, hormonalna terapia zastępcza, ciąża i okres połogu, czynna choroba nowotworowa, $\geq 2$ czynniki ryzyka zakrzepowego) zaleca się stosowanie PSU albo LMWH (zalecenie „słabe”, brak dowodów na skuteczność); e) w przypadku braku możliwości zastosowania PSU i LMWH sugeruje się zażycie ASA (http://www.hematology.org/Clinicians/ /Guidelines-Quality/Guidelines.aspx).

\section{Leczenie VTE u chorych na nowotwory złośliwe}

W myśl wytycznych dotyczących profilaktyki i leczenia VTE, opracowanych w 2016 roku przez ekspertów z American College of Chest Physicians i zaakceptowanych przez Międzynarodowe Towarzystwo Zakrzepicy i Hemostazy (ISTH, International Society on Thrombosis And Haemostasis), bezpośrednio działające doustne antykoagulanty (DOAC, direct oral anticoagulants) - inhibitory czynnika Xa lub trombiny, tj. apiksaban, rywaroksaban, edoksaban i dabigatran, są lekami preferowanymi w pierwszych 3 miesiącach leczenia VTE u pacjentów bez choroby nowotworowej. Uzasadnieniami tego zalecenia są podobna skuteczność $\mathrm{w}$ porównaniu $z$ doustnym antykoagulantem $z$ grupy antagonistów witaminy $\mathrm{K}$ (VKA, vitamin K antagonist), obniżone ryzyko poważnych krwawień, w tym krwawień śródczaszkowych i krwotocznych udarów mózgu, oraz większy komfort leczenia. Zachorowalność na VTE wśród pacjentów $z$ aktywną chorobą nowotworową jest 4-8-krotnie większa niż w ogólnej populacji, większe jest również zagrożenie nawrotem zakrzepicy, mimo prawidłowego leczenia. Leczenie VTE u chorych na nowotwory złośliwe stanowi trudny problem nie tylko ze względu na zwiększone ryzyko nawrotu, lecz także $z$ powodu zwiększonego ryzyka poważnych krwawień wynikającego z często występującej małopłytkowości, uszkodzenia śluzówek lub konieczności wykonywania inwazyjnych zabiegów. W aktualnych wytycznych przewiduje się stosowanie u tych chorych LMWH, s.c. przez 3-6 miesięcy. Skuteczność i bezpieczeństwo DOAC w zakrzepicy związanej z chorobą nowotworową nie są znane, gdyż do randomizowanych badań klinicznych nad leczeniem VTE $z$ zastosowaniem DOAC, obejmujących duże grupy pacjentów, włączono tylko 2,5-9,4\% pacjentów $z$ nowotworami. W grupie kontrolnej u większości chorych stosowano warfarynę, a przecież $\mathrm{w}$ randomizowanym badaniu klinicznym wykazano znamiennie większy odsetek nawrotów VTE u pacjentów $z$ chorobą nowotworową leczonych przez pierwszych 6 miesięcy z zastosowaniem leku $z$ grupy VKA, w porównaniu $z$ leczonymi LMWH. 
Do badania Hokusai VTE-Cancer, przeprowadzonego w 114 ośrodkach w 13 krajach, włączono 1050 pacjentów $z$ aktywnym nowotworem i objawową (67\%) lub incydentalną VTE. U 53\% z nich stwierdzono nowotwór w stadium uogólnionym. Wszyscy pacjenci byli leczeni początkowo LMWH przez 5 dni, a następnie poddani randomizacji do 2 grup. Grupa badana otrzymywała doustny inhibitor czynnika Xa - edoksaban w dawce $60 \mathrm{mg}$ raz/dobę (30 mg w przypadku współczynnika filtracji kłębuszkowej [GFR, glomerular filtration rate] 30-50 ml/min albo masy ciała $<60 \mathrm{~kg}$ ). $\mathrm{W}$ grupie kontrolnej stosowano $200 \mathrm{jm} . / \mathrm{kg} \mathrm{mc}$. dalteparyny s.c. raz/dobę przez miesiąc, a w dalszym leczeniu zmniejszano jej dawkę do $150 \mathrm{jm} . /$ $/ \mathrm{kg} \mathrm{mc}$. raz/dobę. W tym badaniu typu non-inferiority w ciągu 12 miesięcy oceniono częstość wystąpienia złożonego punktu końcowego - nawrotu VTE i poważnego krwawienia oraz oddzielnie częstość nawrotów VTE i poważnych krwawień oraz czas do wystąpienia nawrotu lub poważnego krwawienia. Pierwotny punkt końcowy wystapił u $12,8 \%$ pacjentów leczonych edoksabanem i u 13,5\% pacjentów $z$ grupy leczonej dalteparyną. Podobne były częstość poważnych krwawień (u 12 pacjentów w każdej z grup) oraz czas do wystąpienia powikłań w obu grupach. Ocena skuteczności i bezpieczeństwa stosowania edoksabanu $\mathrm{w}$ porównaniu $\mathrm{z}$ dalteparyną w leczeniu VTE u chorych na nowotwory złośliwe wykazała równoważność obu tych metod (LBA-6).

\section{Kiedy można zakończyć leczenie przeciwkrzepliwe u pacjenta $z$ VTE związaną z chorobą nowotworową?}

Według Rochester Epidemiology Project ryzyko nawrotu VTE i ryzyko poważnych krwawień $\mathrm{u}$ chorych na nowotwory złośliwe przewlekle leczonych przeciwkrzepliwie $z$ powodu VTE wynosi odpowiednio $16,6 \%$ w porównaniu $z 2,0 \%$ po 6 miesiącach i $19,6 \%$ w porównaniu z $4 \%$ po roku. Jak dotąd nie ma zaleceń, w których określono by optymalny czas leczenia przeciwkrzepliwego $\mathrm{w}$ tej grupie chorych. Podstawą decyzji o przerwaniu lub kontynuacji leczenia powinna być indywidualna ocena ryzyka nawrotu, ryzyka krwawienia, preferencji pacjenta i wyników leczenia choroby nowotworowej. W praktyce zaleca się leczenie LMWH przez co najmniej 3 miesiące w przypadku DVT, a przez 6 miesięcy u chorych z PE, która wiąże się $\mathrm{z}$ dużą śmiertelnością $\mathrm{w}$ przypadku nawrotu. Po zakończeniu początkowego leczenia, a następnie co 3 miesiące, należy ponownie oceniać wskazania do kontynuacji leczenia przeciwkrzepliwego $\mathrm{i}$ jego tolerancję ze strony pacjenta. $U$ chorych na nowotwory przewodu pokarmowego lub układu moczowo-płciowego, u których powikłania krwotoczne występują najczęściej, należy odpowiednio zmniejszać dawkę leku przeciwkrzepliwego i stosować inne metody ograniczające krwawienia, na przykład radioterapię lub embolizację. Przewlekłe leczenie przeciwkrzepliwe jest wskazane u następujących pacjentów: a) z uogólnioną chorobą nowotworową lub progresją choroby nowotworowej; b) w trakcie chemioterapii lub przyjmujących leki immunomodulujące; c) $\mathrm{z}$ rakiem trzustki, górnego odcinka przewodu pokarmowego, płuc, jajnika, glejakami mózgu lub MPN; d) z VTE w wywiadzie. W uzgodnieniu $z$ pacjentem należy wybrać optymalny lek przeciwkrzepliwy - LMWH, doustny lek z grupy VKA lub DOAC. Poinformowanie chorego o braku wystarczającej ilości danych na temat skuteczności $\mathrm{i}$ bezpieczeństwa DOAC $\mathrm{w}$ początkowym leczeniu VTE u chorych na nowotwory złośliwe, często powoduje zgodę pacjenta na kontynuowanie leczenia LMWH. Po 6 miesiącach wielu pacjentów wybiera lek doustny (VKA albo DOAC), którego włączenie wymaga oceny interakcji $z$ lekami przeciwnowotworowymi, a także oceny czynności wątroby, nerek i zaburzeń ze strony przewodu pokarmowego. Wskazaniami do zakończenia leczenia przeciwkrzepliwego są ustąpienie wykładników aktywnej choroby nowotworowej w przypadku guzów litych lub uzyskanie remisji w przypadku nowotworów hematologicznych, a także finalne niepowodzenie leczenia przeciwnowotworowego (Hematology Am. Soc. Hematol. Educ. Program 2017: 128-135).

\section{Skuteczność i bezpieczeństwo stosowania rywaroksabanu w porównaniu $z$ warfaryną w leczeniu VTE u pacjentów z trombofilią}

Nie wiadomo, czy rywaroksaban jest lekiem wystarczająco skutecznym w leczeniu VTE $\mathrm{u}$ chorych $z$ trombofilią, gdyż diagnostyki trombofilii nie przeprowadzano przy włączaniu pacjentów do badania EINSTEIN-DVT (Oral Direct Factor Xa Inhibitor Rivaroxaban in Patients with Acute Symptomatic Deep Vein Thrombosis) ani EINSTEIN-PE (Oral Direct Factor Xa Inhibitor Rivaroxaban in Patients with Acute Symptomatic Pulmonary Embolism). Autorzy ocenili wyniki leczenia VTE (częstość nawrotów zakrzepicy, poważnych krwawień, krwawień śródczaszkowych i krwawień $z$ przewodu pokarmowego) u 403 pacjentów $z$ trombofilią leczonych rywaroksabanem, w porównaniu z 403 pacjentami, u których stosowano warfarynę. Średni wiek pacjentów wynosił $50 \pm 14$ lat, PE rozpoznano u 53\% osób, mężczyźni stanowili 50\%, $12 \%$ pacjentów było hospitalizowanych w ciągu 
180 dni przed wystąpieniem epizodu VTE. Średni czas leczenia wynosił 0,5 \pm 3 lata. Nie stwierdzono istotnych statystycznie różnic w zakresie częstości nawrotu VTE, częstości poważnych krwawień ani krwawień $z$ przewodu pokarmowego między badanymi grupami. Tylko u 2 pacjentów leczonych warfaryną doszło do krwotoku wewnątrzczaszkowego. $Z$ badania wynika wniosek, że rywaroksaban jest lekiem podobnie skutecznym i bezpiecznym jak warfaryna w leczeniu VTE u chorych na trombofilię (streszczenie 1113).

\section{Płytkowe skazy krwotoczne prof. dr hab. n. med. Krzysztof Chojnowski}

W trakcie konferencji ASH w 2017 roku płytkowym skazom krwotocznym poświęcono wiele interesujących doniesień, ze znaczącym udziałem polskich naukowców. Zdecydowana większość $z$ nich dotyczyła pierwotnej małopłytkowości immunologicznej (ITP, primary immune thrombocytopenia). Glikokortykosteroidy (GKS) pozostają lekami pierwszej linii w leczeniu chorych na ITP. Obecnie coraz częściej stosuje się deksametazon w 4-dniowych pulsach w dawce $40 \mathrm{mg}$ /dobę. Zwykle podaje się 1-4 kursów leczenia w odstępach 2-tygodniowych. Mimo wysokiego odsetka wczesnych odpowiedzi u większości pacjentów dochodzi do nawrotu ciężkiej małopłytkowości. Ishijama i wsp. (streszczenie 1050) przeprowadzili retrospektywną analizę wyników leczenia pulsami deksametazonu. Wzrost liczby PLT do 30 G/1 lub więcej, z co najmniej 2-krotnym zwiększeniem wyjściowej liczby PLT w pierwszym tygodniu leczenia, okazał się niezależnym czynnikiem predykcyjnym długotrwałej odpowiedzi płytkowej.

W celu poprawy wyników początkowego leczenia czynione są próby kojarzenia GKS z lekami o innym mechanizmie działania. Warte odnotowania są wyniki randomizowanego wieloośrodkowego badania służącego porównaniu skuteczności dużych dawek deksametazonu stosowanego $\mathrm{w}$ monoterapii (HDD, high-dose dexamethasone) i w połączeniu $z$ rekombinowaną ludzką trombopoetyną (HDD + rhTPO [recombinant human thrombopoietin]) w pierwszej linii leczenia chorych na ITP (streszczenie 13). Ponieważ deksametazon działa immunosupresyjnie i hamuje niszczenie PLT, a rhTPO zwiększa ich produkcję, a także może przywracać immunotolerancję, badacze wysunęli hipotezę, że leki te mogą działać synergistycznie. Deksametazon stosowano przez 4 kolejne dni, w dawce $40 \mathrm{mg} /$ dobę. W przypadku braku odpowiedzi puls HDD powtarzano w dniach 11.-14.; rhTPO wsytrzykiwano s.c. w dawce $300 \mathrm{j}$./kg mc. przez pierwsze 14 dni lub leczenie przerywano wcześniej w przypadku wzrostu liczby PLT powyżej $100 \mathrm{G} /$ /1. Pierwszorzędowym punktem końcowym był odsetek wszystkich odpowiedzi płytkowych (liczba PLT $\geq 30$ G/l i $\geq 2$-krotny wzrost wyjściowej liczby PLT) i odpowiedzi całkowitych (liczba PLT $\geq 100 \mathrm{G} /$ /1) 14. dnia. Kluczowymi punktami drugorzędowymi były wyżej wspomniane odpowiedzi po 6 miesiącach, czas trwania odpowiedzi, nasilenie krwawień i występowanie zdarzeń niepożądanych. Spośród 196 poddanych randomizacji pacjentów 96 otrzymało HDD, a 100 HDD + rhTPO. Wyższy odsetek wczesnych odpowiedzi obserwowano w grupie leczonej HDD + rhTPO niż u osób leczonych samym deksametazonem $(89,0 \% v .66,7 \%$; $\mathrm{p}<0,001)$, w tym CR $(75,0 \%$ v. 42,7\%; $\mathrm{p}<0,001)$. Po 6 miesiącach odpowiedź płytkowa utrzymywała się również znamiennie częściej w grupie leczonej HDD + rhTPO $(51,0 \% v .36,5 \% ; \mathrm{p}=0,22), \mathrm{w}$ tym CR (46,0\% v. 32,3\%; $\mathrm{p}=0,043)$. Nie stwierdzono istotnych różnic między badanymi grupami w zakresie krwawień i konieczności stosowania terapii ratunkowej. Grupy nie różniły się również pod względem występowania zdarzeń niepożądanych.

Ważnym wydarzeniem, i to $z$ polskim akcentem, było przedstawienie wyników randomizowanego, wieloośrodkowego, kontrolowanego placebo, badania III fazy dotyczącego skuteczności i bezpieczeństwa stosowania avatrombopagu w ITP (streszczenie 17). Avatrombopag jest agonistą receptora trombopoetyny (TPO-RA, trombopoietin-receptor agonist) II generacji podawanym p.o. Wyniki badania prezentował prof. Wojciech Jurczak z Uniwersytetu Jagielońskiego w Krakowie. Badaniami objęto 49 pacjentów $z$ przewlekłą, pierwotną ITP, których poddano randomizacji do grup leczonej avatrombopagiem i przyjmującej placebo w stosunku 2:1. Dawkę leku dostosowywano do odpowiedzi płytkowej (5-40 mg/d.). Pierwszorzędowym punktem końcowym była skumulowana liczba tygodni $z$ liczbą PLT $50 \mathrm{G} / \mathrm{l}$ i większą. W ramach drugorzędowych punktów końcowych oceniano odpowiedź płytkową 8. dnia leczenia i odsetek pacjentów $z$ ograniczonym leczeniem towarzyszącym. Analiza bezpieczeństwa obejmowała monitorowanie zdarzeń niepożądanych oraz wyników badań laboratoryjnych. W grupie leczonej TPO-RA liczba tygodni $z$ liczbą PLT co najmniej $50 \mathrm{G} / 1$ wynosiła 12,4 $\mathrm{W}$ porównaniu $\mathrm{z} 0 \mathrm{~W}$ grupie przyjmującej placebo $(\mathrm{p}<0,0001)$. Odpowiedź płytkową 8. dnia leczenia uzyskało $65,6 \%$ pacjentów leczonych avatrombopagiem; w grupie przyjmującej placebo nie było ani 1 takiego pacjenta $(\mathrm{p}<0,0001)$. Ograniczenie leczenia towarzyszącego dotyczyło ponad $33 \%$ chorych 
z grupy leczonej avatrombopagiem, natomiast nie była możliwa u żadnej osoby otrzymującej placebo. Długotrwałą odpowiedź płytkową obserwowano znamiennie częściej $\mathrm{w}$ grupie poddanej terapii avatrombopagiem $(34,3 \%$ v. 0\%; $\mathrm{p}<0,009)$. Poważne zdarzenia niepożądane nie różniły się istotnie między badanymi grupami. Najczęściej raportowanymi zdarzeniami niepożądanymi były bóle głowy, infekcje górnych dróg oddechowych, bóle stawów i krwawienia $z$ nosa. Wyniki badań wskazują, że avatrombopag jest skutecznym i dobrze tolerowanym lekiem u chorych na przewlekłą ITP. Można zatem oczekiwać rejestracji trzeciego TPO-RA do leczenia drugiej linii pacjentów z pierwotną ITP.

Bliższe poznanie złożonej patogenezy ITP otworzyło nowe możliwości leczenia tej choroby. $\mathrm{Na}$ konferencji ASH w 2017 roku przedstawiono wstępne wyniki badania II fazy dotyczącego bezpieczeństwa i skuteczności rozanoliksizumabu w leczeniu utrzymującej się lub przewlekłaj ITP (streszczenie 15). Rozanoliksizumab jest monoklonalnym humanizowanym przeciwciałem skierowanym przeciwko noworodkowemu receptorowi Fc (FcRn, neonatal Fc receptor). W komórkach śródbłonka $\mathrm{FcRn}$ odgrywa ważną rolę w ochronie IgG przed katabolizmem wewnątrzkomórkowym i przyczynia się do długiego okresu jej półtrwania. Rozanoliksizumab zaprojektowano w celu obniżenia stężenia patologicznej IgG w chorobach autoi alloimmunizacyjnych. Wyniki badania prezentowa1 na sesji doniesień ustnych prof. Tadeusz Robak z Kliniki Hematologii w Łodzi. Pośrednia analiza objęła 28 wcześniej leczonych chorych na ITP z liczbą PLT poniżej $30 \mathrm{~g} / 1$. Pacjenci otrzymywali rozanoliksizumab s.c. raz $\mathrm{w}$ tygodniu $\mathrm{w}$ dawkach $4 \mathrm{mg} / \mathrm{kg}$ mc. (5 dawek) i $7 \mathrm{mg} / \mathrm{kg} \mathrm{mc}$. (3 dawki). Lek był dobrze tolerowany niezależnie od dawki. Zdarzenia niepożądane raportowano u 18 spośród 28 badanych. Najczęściej były to bóle głowy, biegunka i objawy grypopodobne. Tylko w jednym przypadku zgłoszono ciężkie zdarzenie niepożądane, niezwiązane $z$ lekiem. Nie obserwowano infekcji oportunistycznych. Średnie maksymalne obniżenie stężenia IgG wystąpiło 29. dnia przy dawce rozanoliksizumabu wynoszącej $4 \mathrm{mg} / \mathrm{kg} \mathrm{mc}$. i 22 . dnia w grupie otrzymującej lek w dawce $7 \mathrm{mg} / \mathrm{kg} \mathrm{mc}$. Odpowiedź płytkową ( $\geq 50 \mathrm{G} / \mathrm{l}$ ) obserwowano u 8 pacjentów $z$ grupy przyjmującej rozanoliksizumab w dawce $4 \mathrm{mg} / \mathrm{kg} \mathrm{mc}$. i u 4 pacjentów $z$ grupy leczonej dawką $7 \mathrm{mg} / \mathrm{kg} \mathrm{mc}$.

Na uwagę zasługuje praca dotycząca stosowania atorwastatyny w małopłytkowości samoistnej opornej na GKS (streszczenie 232). Autorzy wysunęli hipotezę, że ilościowe/lub jakościowe zabu- rzenia progenitorowych komórek śródbłonka mogą być jedną z przyczyn oporności na GKS w ITP. We wcześniejszych badaniach na myszach wykazano ważną rolę tych komórek w regulacji trombocytopoezy. $Z$ kolei w badaniach in vitro udowodniono, $\dot{z}$ e atorwastatyna może korzystnie wpływać na ich czynność i liczbę. Celem pracy były: analiza zależności między ilościowymi i czynnościowymi zaburzeniami progenitorowych komórek śródbłonka a oporną na GKS ITP, ocena wpływu atorwastatyny i N-acetyl-L-cysteiny (NAC) na liczbę i funkcję tych komórek oraz na liczbę PLT u opornych na GKS pacjentów $z$ ITP. Badaniami objęto 40 pacjentów z ITP i 30 zdrowych ochotników. W badaniach in vitro stwierdzono zmniejszenie liczby i zaburzenie czynności progenitorowych komórek śódbłonka w szpiku chorych na ITP oporną na GKS. Zaburzenia czynności tych komórek przejawiały się zmniejszeniem potencjału proliferacyjnego, zdolności do migracji i angiogenezy, wyższą zawartością wolnych rodników tlenowych i apoptozą. Dodanie atorwastatyny lub NAC do hodowli progenitorowych komórek śródbłonka korzystnie wpływało na ich liczbę i czynność. U 13 pacjentów z ITP oporną na GKS zastosowano atorwastatynę w monoterapii lub w skojarzeniu z NAC. Odpowiedź płytkową obserwowano u 9 spośród 13 (69,2\%), a odpowiedź całkowitą u 3 spośród 13 (23,1\%) pacjentów. Mediana czasu do uzyskania odpowiedzi wynosiła $24 \mathrm{dni}$.

Bardzo interesujące doniesienie dotyczące potencjalnej roli DEC w leczeniu ITP przedstawili Han i wsp. (streszczenie 229). Decytabinę, lek hipometylujący, stosuje się w leczeniu chorych na MDS. Jednym $z$ efektów jej działania jest wzrost liczby PLT. We wcześniejszych badaniach wykazano, że DEC w sposób długotrwały zwiększa odsetek dojrzałych megakariocytów u chorych na ITP. Ostatnie doniesienia wskazują, że DEC może zmniejszać produkcję IFN $\gamma$ i TNF $\alpha$, a jednocześnie zwiększać liczbę regulatorowych komórek T (Treg). $\mathrm{Na}$ tej podstawie autorzy wysunęli hipotezę, że małe dawki DEC mogą przywracać tolerancję immunologiczną i indukować długotrwałą odpowiedź płytkową u pacjentów z ITP. W pierwszej części pracy wykazano, że leczenie DEC chorych na ITP $(3,5 \mathrm{mg} /$ $/ \mathrm{m}^{2} /$ d. DEC przez 3 dni, 3 cykle co 4 tygodnie) prowadzi do istotnego wzrostu liczby i funkcji Treg i jednocześnie do zmniejszenia odsetka limfocytów CD4 + IFN $\gamma+$ TH1 i monocytów CD16+. Następnie na myszach poddanych immunizacji przeciwko PLT udowodniono korzystny wpływ leczenia małymi dawkami DEC $(0,01,0,03$ lub $0,1 \mathrm{mg} / \mathrm{kg} \mathrm{mc}$.) 3 razy $\mathrm{w}$ tygodniu i.v. Obserwowano wzrost liczby PLT i Treg, $z$ jednoczesną supresją TH1 i monocytów. 
Spośród innych doniesień warta odnotowania jest praca dotycząca oceny czynników ryzyka krwawień u pacjentów $z$ nowo rozpoznaną ITP (streszczenie 1041). Do prospektywnej analizy włączono 302 pacjentów. Analiza wielowariantowa wykazała, że wysokie ryzyko krwawień (wszystkie krwawienia niezależnie od ich rodzaju i lokalizacji) występowało przy liczbie PLT poniżej $20 \mathrm{G} / 1$ i było istotnie wyższe u kobiet i osób stosujących niesteroidowe leki przeciwzapalne. Tylko liczba PLT poniżej $10 \mathrm{G} / 1$ wiązała się $z$ krwawieniami śluzówkowymi, natomiast ciężkie krwawienia nie były istotnie związane $z$ liczbą PLT, lecz $z$ dodatkowymi czynnikami, a przede wszystkim z przyjmowaniem leków przeciwkrzepliwych.

$\mathrm{Na}$ uwagę zasługuje również doniesienie poświęcone wpływowi rodzaju przeciwciał przeciwpłytkowych na miejsce niszczenia PLT (streszczenie 1046). Badania wykonano u 55 pacjentów z utrzymującą się lub przewlekłą ITP. Miejsce sekwestracji PLT w wątrobie i śledzionie badano przy użyciu autologicznych PLT znakowanych indem ${ }^{111}$. U $51 \%$ pacjentów stwierdzono śledzionowy, a u $49 \%$ śledzionowo-wątrobowy typ sekwestracji PLT. Przeciwciała przeciwko GP wykryto u 54\% pacjentów. Stosując model regresji liniowej, wykazano istotną zależność między obecnością przeciwciał przeciwko GP a niszczeniem PLT w śledzionie. Obecność przeciwciał anty-GPIIb/ /IIIa i anty-GPIb/IX nie miała związku $z$ miejscem niszczenia PLT. Śledzionowy typ sekwestracji występował znamiennie częściej u osób poniżej 30. roku życia. Wyniki tej pracy mogą mieć znaczenie przy kwalifikacji chorych na ITP do splenektomii.

Wyniki badań nad nowymi metodami terapii ITP potwierdzają złożoną i skomplikowaną patogenezę tej choroby, co tłumaczy nieprzewidywalną odpowiedź na stosowane leki. Można oczekiwać, że w przyszłości podstawą leczenia chorych na ITP będzie indywidualnie dobrana terapia ukierunkowana na dominujący mechanizm odpowiedzialny za małopłytkowość.

\section{Wrodzone skazy krwotoczne \\ dr n. med. Andrzej Mital}

Od kilku lat obserwuje się znaczny postęp w leczeniu wrodzonych skaz krwotocznych, a w szczególności w hemofilii A i B. W przeszłości lekami $\mathrm{z}$ wyboru w leczeniu krwawień w tej grupie pacjentów były osocze i krioprecypitat, a pojawienie się koncentratów poszczególnych czynników krzepnięcia było jednym $z$ pierwszych przełomów w terapii hemofilii. Umożliwiało to szybkie podanie małej objętości leku, w krótkim czasie i w warunkach domowych. Niestety, podawanie osoczopochodnych koncentratów czynników krzepnięcia wiązało się z dużym ryzykiem zakażeń, w tym zwłaszcza wirusami hepatotropowymi i ludzkim wirusem nabytego niedoboru odporności (HIV, human immunodeficiency syndrome). Po udoskonaleniu procesów produkcji koncentraty czynników krzepnięcia stały się o wiele bardziej bezpieczne i praktycznie nie dochodzi już do tego typu zakażeń, ale nie można w $100 \%$ wykluczyć obecności innych patogenów. Nadal w wielu krajach, w tym w Polsce, stosuje się osoczopochodne koncentraty czynnika krzepnięcia VIII i IX. Kolejnym postępem w leczeniu tych chorych było wprowadzenie rekombinowanych czynników krzepnięcia, obecnie dostępnych $\mathrm{w}$ postaci różnych generacji, co wiąże się $z$ brakiem możliwości ewentualnych zakażeń. Nadal niedogodnością w stosowaniu tych preparatów jest konieczność iniekcji i.v. Postęp w leczeniu stanowi również wprowadzenie profilaktyki, co zapobiega artropatii i zmniejsza liczbę wylewów, ale wiąże się z częstym, 2-3 razy w tygodniu, podawaniem czynnika krzepnięcia i.v. Dostępne są preparaty o przedłużonym okresie półtrwania, co znacznie zmniejsza częstotliwość podawania. Osiągnięto to między innymi drogą pegylacji, przyłączeniem albuminy czy fragmentu Fc przeciwciała. Leczenie koncentratami czynników krzepnięcia może być powikłane wytworzeniem inhibitora, którego obecność skutkuje brakiem skuteczności leczenia i profilaktyki. $W$ większości przypadków w leczeniu krwawień stosuje się rekombinowany czynnik VIIa (rFVIIa, recombinant factor VIIa), zespół aktywowanych czynników zespołu protrombiny (APCC-FEIBA [activated prothrombin complex concentrate - factor VIII inhibitor by passing activity]) oraz ostatnio świński rFVIII. Leki te również wymagają iniekcji i.v. W celu poprawienia skuteczności i wygody leczenia pacjentów $z$ hemofilią rozpoczęto badania nad lekami o przedłużonym działaniu podawanymi s.c.

W trakcie konferencji ASH w 2017 roku, na sesji poświęconej nowym terapiom i badaniom klinicznym we wrodzonych skazach krwotocznych, najwięcej miejsca poświęcono emicizumabowi. Jest to bispecyficzne przeciwciało monoklonalne, które zastępuje działanie FVIIIa poprzez wiązanie się z FIXa oraz FX w celu zblizenia ich do siebie na odległość umożliwiającą aktywację FX przez FIXa. Powoduje to inicjację dalszych etapów kaskady krzepnięcia i przywrócenie prawidłowego funkcjonowania układu krzepnięcia. Okres półtrwania leku wynosi 4-5 tygodni. Emicuzumab nie jest inaktywowany przez przeciwciała przeciwko FVIII 
(inhibitor) i w związku $z$ tym może być stosowany zarówno u pacjentów $z$ hemofilią $A$ bez inhibitora, jak i z jego obecnością. Lek stosuje się s.c. W badaniu HAVEN1 (A Randomized, Multicenter, Open-Label, Phase III Clinical Trial to Evaluate the Efficacy, Safety, and Pharmacokinetics of Prophylactic Emicizumab Versus no Prophylaxis in Hemophilia A Patients With Inhibitors) u pacjentów $z$ inhibitorem emicuzumab podawano profilaktycznie raz $\mathrm{w}$ tygodniu w dawce $1,5 \mathrm{mg} / \mathrm{kg} \mathrm{mc}$. Osiągnięto 87-procentowe zmniejszenie częstości krwawień w stosunku do pacjentów niepoddanych profilaktyce. Główne ciężkie działania niepożądane (zakrzepica, mikroangiopatia zakrzepowa) wiązały się $z$ dodatkowym stosowaniem preparatów omijających inhibitor. Na konferencji ASH w 2017 roku przedstawiono wstępne wyniki badania HAVEN2 z udziałem dzieci i młodzieży poniżej 12 . roku życia $z$ hemofilią A powikłaną inhibitorem (streszczenie 85). Była to analiza etapowa wieloośrodkowego badania III fazy prowadzonego metodą otwartej próby w pojedynczej grupie. Profil bezpieczeństwa emicuzumabu był korzystny, a lek - dobrze tolerowany. Nie odnotowano incydentów zakrzepowo-zatorowych ani mikroangiopatii zakrzepowej. Zaktualizowane wyniki badania HAVEN2 potwierdzają wcześniejsze wyniki dotyczące skuteczności - emicizumab skutecznie zapobiegał krwawieniom bądź zmniejszał ich nasilenie. Wykazano klinicznie istotne obniżenie współczynnika krwawień w skali roku $\mathrm{w}$ grupie leczonej emicizumabem w porównaniu $z$ wcześniejszym leczeniem preparatami omijającymi inhibitor.

Podczas ostatniej konferencji ASH przedstawiono również wyniki dotyczące pacjentów przechodzących zabiegi chirurgiczne w trakcie udziału w badaniu HAVEN1/2 (streszczenie 89). Większość osób leczonych emicizumabem poddanych małym zabiegom chirurgicznym nie otrzymywała preparatów omijających inhibitor, a krwawienia pooperacyjne występowały rzadko. Trwa badanie HAVEN4 - wstępne wyniki 7 chorych przedstawili Jimenez-Yuste i wsp. (streszczenie 86). Pacjenci powyżej 12. roku życia $z$ hemofilią $\mathrm{A}$, bez $(\mathrm{n}=4)$ lub $z$ obecnością inhibitora $(n=3)$, otrzymywali emicuzumab w dawce $6 \mathrm{mg} / \mathrm{kg} \mathrm{mc}$. podawanej s.c. co 4 tygodnie. Tylko u 1 pacjenta wystąpiło krwawienie $z$ nosa, niewymagające leczenia. Nie obserwowano objawów niepożądanych, poza 1 przypadkiem pogorszenia kontroli ciśnienia tętniczego. Do badania włączono 48 chorych i na końcowe wyniki należy jeszcze poczekać.
Najważniejsze doniesienia naukowe

Konferencji ASH w 2017 roku

prof. dr hab. n. med. Krzysztof Warzocha

Temat wybrany przeze mnie, jako jeden $z$ ważniejszych opublikowanych w trakcie ostatniej konferencji ASH, to nowatorskie wykorzystanie znanych już wcześniej technologii polegające na sekwencyjnym wykorzystaniu przeciwcial monoklonalnych o różnym mechanizmie działania oraz chemioterapii. Co istotne, projekt był realizowany w ramach międzynarodowego konsorcjum naukowego - INHARMONY, którego zadaniem jest wyodrębnienie drogą eksperymentówe medycznych I/II fazy, przeprowadzanych z udziałem mało licznych grup chorych na chłoniaki, a tym samym - w relatywnie szybkim czasie, optymalnych połączeń różnych leków i stategii terapeutycznych, a także poznanie nowych czynników predykcyjnych wystąpienia optymalnej jakości odpowiedzi na tak stosowane leczenie. Warty podkreślenia jest fakt, że ten europejski projekt naukowy jest realizowany przy udziale kilkudziesięciu podmiotów sektora publicznego i prywatnego, w tym szpitali akademickich, instytutów i firm farmaceutycznych. Między innymi dlatego zasługiwał na wyróżnienie jako jedno $\mathrm{z}$ ciekawszych publikacji na ostatniej Konferencji ASH.

Younes i wsp. (streszczenie 481) wykazali w badaniu fazy Ib/II, że zastosowanie w pierwszej linii leczenia chorych na FL sekwencyjnej immunoterapii atezolizumabem (anty-PD-L1) oraz obinutuzumabem (anty-CD20) i chemioterapii (bendamustyna) umożliwia uzyskanie odsetka obiektywnych odpowiedzi na poziomie $85 \%$, $\mathrm{w}$ tym $75 \%$ CR i $10 \%$ PR - zgodnie ze zmodyfikowanymi w Lugano kryteriami odpowiedzi PET/ /tomografia komputerowa (2014 r.). Ponadto u 10\% chorych stwierdzono SD. Badacze wykazali także negatywizację molekularną MRD po zakończeniu leczenia indukującego u wszystkich 16 chorych wykazujących krążące DNA guza przed rozpoczęciem leczenia.

$\mathrm{W}$ indukcji remisji zakładano trwające 6 miesięcy leczenie, $z$ następowym 2-letnim okresem leczenia podtyrzymującego. Pierwszy cykl leczenia indukującego składał się jedynie $z$ obinutuzumabu w dawce $1000 \mathrm{mg}$ i.v. w dniach 1., 8., i 15. oraz bendamustyny w dawce $90 \mathrm{mg} / \mathrm{m}^{2} i . v$. w dniach 1. i2. W ramach cykli immunochemioterapii, od 2 do 6 podawanych co 28 dni, zakładano zastosowanie tripletu, na który składały się obinutuzumab $\mathrm{w}$ dawce $1000 \mathrm{mg}$ i.v. 1. dnia, bendamustyna w dawce 
$90 \mathrm{mg} / \mathrm{m}^{2}$ i.v. 1. i 2. dnia oraz atezolizumab w dawce $840 \mathrm{mg}$ i.v. 1. i 15. dnia. W leczeniu podtrzymującym zakładano podawanie obinotuzumabu raz/ /2 miesiące (dzień 1.) i atezolizumabu raz/miesiąc (dzień 1 i 2). Kohorta próbna liczyła 42 chorych, którą następnie zwiększono o kolejnych 36 chorych. Wyniki badań dotyczące skuteczności, przedstawione w trakcie konferencji ASH w 2017 roku, dotyczyły 42 chorych, którzy ukończyli protokół leczenia. Mediana wieku tych chorych wynosiła 57 lat (zakres 29-75); 52\% stanowili mężczyźni, u 93\% stopień zawansowania klinicznego III/ /IV według Ann Arbor, 21\% wykazywało obecność zmian masywnych (> $7 \mathrm{~cm})$, a $48 \%$ - zajęcie szpiku kostnego. W ocenie histopatologicznej w $71 \%$ przypadków stwierdzono podtyp G2 lub G3A. U 24\% chorych stwierdzono FLIPI niskiego ryzyka, u $43 \%$ - ryzyka pośredniego, a u $33 \%$ - wysokiego ryzyka.

U wszystkich leczonych chorych stwierdzono wystąpienie działań niepożądanych. Odsetek działań niepożądanych w stopniu 3. lub 4. wyniósł $57 \%$, w tym poważnych $29 \%$. W $10 \%$ przypadków objawy niepożądane zdecydowały o przedwczesnym zakończeniu leczenia, u kolejnych $10 \%$ spowodowały zmniejszenie dawki bendamustyny, a w $57 \%$ przypadków wpłynęły na czasowe przerwanie leczenia. Najczęstszymi hematologicznymi objawami niepożądanymi w stopniu 3. lub 4 . w okresie leczenia indukującego były neutropenia $(\mathrm{n}=11)$ i małopłytkowość $(n=2)$. Ponadto u 3 chorych odnotowano istotny wzrost aktywności lipazy (stopień 3.), który pojawił się również u 2 chorych w okresie leczenia indukującego. Co istotne, badacze odnotowali wystąpienie 12 różnych objawów niepożądanych u $17 \%$ chorych, które mogły mieć szczególne znaczenie dla badanej strategii leczniczej. W okresie indukcji należały do nich objawy związane $z$ infuzją w stopniu 1. lub 2. ( $\mathrm{n}=3$ ), wzrost aktywności lipazy w stopniu 4. $(\mathrm{n}=1)$, wysypka w stopniu 2 . $(\mathrm{n}=1)$, zapalenie mięśnia sercowego w stopniu 4 . $(\mathrm{n}=1)$ i zapalenie oskrzelików w stopniu 1. $(\mathrm{n}=1)$. W okresie leczenia podtrzymującego do takich objawów niepożądanych należały: wzrost aktywności lipazy w stopniu 4 . u 2 chorych, zapalenie skóry w stopniu 2. u 1 chorego, zapalenie jelita grubego w stopniu 3. u 1 chorego. Stwierdzono również 2 zgony, w tym jeden $z$ powodu zapalenia mięśnia sercowego i oskrzelików oraz jeden $z$ nieznanych przyczyn.

Wyniki prezentowanego badania podkreślają rosnącą rolę immunoterapii $\mathrm{w}$ leczeniu indukującym i podtrzymującym chorych na FL, a tym samym coraz mniejsze znaczenie klasycznej chemioterapii w tym wskazaniu klinicznym. Należy podkreślić znaczenie sekwencyjnego podawania przeciwciał monoklonalnych o różnych mechanizmach działania, w tym uwalniających antygeny nowotworowe $z$ komórek docelowych (anty-CD20) i następczo aktywujących punkty kontroli immunologicznej (anty-PD-L1). Należy mieć na uwadze ryzyko wystąpienia powikłań immunologicznych, w tym zagrażających życiu, po zastosowaniu wyżej opisanego leczenia. $Z$ jednej strony w dalszych badaniach, w tym opartych na ekspresji specyficznych biomarkerów (PD-L1, CD8 i innych), powinien zostać określony profil pacjenta szczególnie narażonego na wystąpienie działań niepożądanych, a $z$ drugiej chorych mogących odnieść największą korzyść $z$ tej strategii leczenia.

\section{Podsumowanie}

W grudniu bieżącego roku czeka nas jubileuszowa, 60. Konferencja ASH w San Diego, a po niej, 1-2 marca 2019 roku, XIII Ogólnopolska Konferencja po ASH w Krakowie. Wszystkich zainteresowanych zapraszam do wzięcia w niej udziału. Jak co roku liczba uczestników jest ograniczona, dlatego o zakwalifikowaniu decyduje kolejność zgłoszeń. Przy tej okazji pragnę podziękować agencji BATUMI za bardzo sprawną, jak zwykle, organizację XII edycji Konferencji po ASH, a firmom farmaceutycznym, w tym sponsorom wiodącym (Celgene i Novartis) i wspierającym (Abbvie, Alexion, Amgen, Angelini, Astellas, Bristol-Myers Squibb, Janssen, Jazz Pharmaceuticals, Pfizer, Roche, Servier, Takeda), za pomoc finansową w ich przeprowadzeniu. 